\title{
PROJETO E DESENVOLVIMENTO DE UMA CÂMARA TÉRMICA PARA TESTES DE TEMPERATURA DE ACORDO COM A NORMA API 6A APÊNDICE F
}

\author{
Projeto de Graduação
}

Trabalho apresentado ao final do curso de Engenharia Mecânica do Departamento de Engenharia Mecânica PUC-Rio como parte dos requisitos à conclusão do curso de Engenharia Mecânica.

Orientador: Carlos Roberto Hall Barbosa

Rio de Janeiro, Dezembro de 2017. 


\section{PROJECT AND DEVELOPMENT OF A THERMAL CHAMBER FOR TEMPERATURE TESTS IN ACCORDANCE WITH API 6A ANNEX F STANDARD}

Undergraduate Final Project

Paper presented at the end of the Mechanical Engineering Undergraduate Course of the Mechanical Engineering Department PUC - Rio as part of the requirements for completing the Mechanical Engineering Course.

Tutor: Carlos Roberto Hall Barbosa

Rio de Janeiro, December 2017. 


\section{AGRADECIMENTOS}

Agradeço em especial à minha mãe, pai, e irmã por todo suporte e carinho. Ao meu primo Lucas que sempre me ajudou e me fez acreditar em mim. À todos meus outros maravilhosos primos Tammy, Pedro, Tomas, Rani, Nanda, Thiago, Kel, Chris, Paty, Ciça, ao meu cunhado João, às minhas avós, tias e tios. Agradeço imensamente à toda essa família incrível.

Agradeço muito aos meus amigos de faculdade Timmy, Fê, Camila, Olga, Pedro, Salomão, Thiago e Bruna que tornaram esses semestres de graduação maravilhosos. Agradeço muito à família que escolhi Fran, Vic, Julia, Dani e Clara.

Agradeço ao meu gestor Girleu por toda inspiração e por tornar este projeto possível; ao engenheiro Artur, por todo apoio e dedicação a me ensinar; e também, à toda equipe do laboratório que contribuíu para a execução dos testes.

Agradeço ao meu orientador, Dr. Carlos Hall, por toda orientação durante o projeto, e a todos meus professores da PUC, que indiretamente contribuíram para este trabalho. 


\section{RESUMO}

Com as descobertas de grandes campos offshore de óleo e gás em meados do século $X X$, essa indústria começou a ser amplamente expandida e a perfuração offshore imensamente lucrativa. Este acelerado crescimento econômico, somado aos desafios crescentes da operação em campo, causaram os primeiros grandes acidentes ambientais, causados em virtude de vazamentos de óleo no mar.

Surgia, então, a necessidade de testes dos equipamentos que garantissem alto nível de confiabilidade e segurança aos projetos. Atualmente, todos os equipamentos de exploração e produção de óleo e gás devem ser submetidos a testes de qualificação rigorosos sob normas internacionais, como por exemplo as normas ISO e API (Americam Petroleum Institute).

Este Projeto de Graduação apresenta o desenvolvimento de uma câmara térmica para testes de temperatura dual zone de qualificação de válvulas gaveta submarinas atuadas, conforme norma API 6A Apêndice F.

Será inicialmente apresentada uma introdução sobre projetos de válvulas gaveta submarinas atuadas segundo a norma API $6 \mathrm{~A}$, e seus testes de qualificação. $O$ teste de temperatura foi estudado detalhadamente para que todos os requisitos da câmara de testes fossem mapeados e o projeto pudesse ser detalhado. A câmara, além de atender aos requisitos do teste, deve ser uma estrutura que permita um setup rápido e que atenda ao prazo de entrega ao laboratório. Assim, foi construído e testado um protótipo para validar a concepção do projeto da câmara e, após análise destes resultados com o protótipo, o projeto foi revisado, fabricado, montado e testado de acordo com a norma API 6A.

A análise dos resultados deste último teste concluiu que os objetivos do projeto foram alcançados.

Palavras-Chave: Testes de qualificação; Válvula gaveta submarina atuada; API 6A Apêndice F; Câmara térmica; Teste de temperatura. 


\section{ABSTRACT}

With the discovery of large oil \& gas offshore fields in the mid 1900's, this industry expanded widely and offshore drilling became very lucrative. This fast economic growth, in addition to the increased challenges of field operations, caused the first great environmental accidents due to sea oil spill. That increased the demand for tests that would guarantee a higher level of trust and safety on such projects.

Nowadays, all oil \& gas drilling and production equipment must be submitted to strict quality control tests under international standards, such as ISO and API (American Petroleum Institute).

This Undergraduate Final Project presents the development of a thermal chamber for temperature testing for subsea actuated gate valves quality control, in accordance to API 6 A Annex F standard.

Initially there will be an introduction of subsea actuated gate valves projects, in accordance to API 6A standard, and its quality control tests. The temperature test was studied in detail in order to map all the test chambers requirements so the project could be detailed. The chamber, in addition to addressing the API 6A test requirements, must have a structure that allows a quick setup and that respects the project's lead time. Therefore, a prototype was built and tested to validate the chamber project concept and, after these results were analyzed, the project was revised, fabricated, assembled and tested in accordance with the API 6A regulation.

The analysis of the results from the last test concluded that the goals for the project were achieved.

Key-Words: Qualification tests; Subsea actuated gate valve; API 6A Annex F; Thermal chamber; Temperature testing. 


\section{SUMÁRIO}

1 INTRODUÇÃO 10

1.1 Breve Introdução à Indústria de Óleo e Gás Offshore 10

1.2 Principais Equipamentos 11

1.3 Normas e Teste de Qualificação 14

1.4 Cenário Atual do Mercado 15

1.5 Objetivo 16

2 VÁLVULA GAVETA SUBMARINA ATUADA 17

2.1 Válvula Gaveta 17

2.2 Projeto e Requisitos Principais 22

2.3 Testes de Qualificação API 6 A Apêndice F 25

3 TESTE DE TEMPERATURA DUAL ZONE 30

3.1 Transferência de Calor 31

3.2 Requisitos e Recursos Necessários 31

3.3 Procedimento de Teste 32

3.4 Análise do Tempo de Teste 36

4 PROJETO DA CÂMARA TÉRMICA DE TESTE 39

4.1 Requisitos e especificações do projeto 39

4.2 Prototipagem 46

4.2.1 Desenvolvimento e Construção do Protótipo 46

4.2.2 Testes do Protótipo 49

4.2.3 Resultados 49

4.3 Design Review - Revisão do Projeto 49

4.4 Fabricação e Montagem da Câmara de Testes 53

5 TESTE DA CÂMARA TÉRMICA 57 
5.1 Montagem do setup

5.2 Teste da Câmara 60

5.3 Resultados 60

5.4 Kaizen: Melhoria Contínua 69

6 CONCLUSÃO 71

REFERÊNCIAS BIBLIOGRÁFICAS 72 


\section{Lista de figuras}

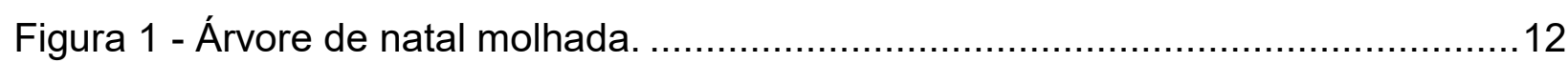

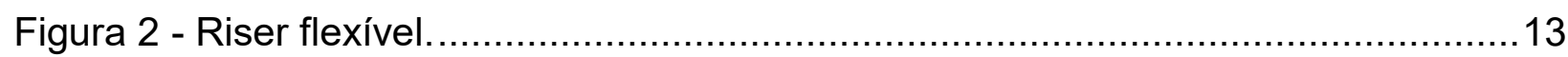

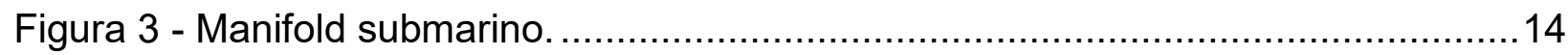

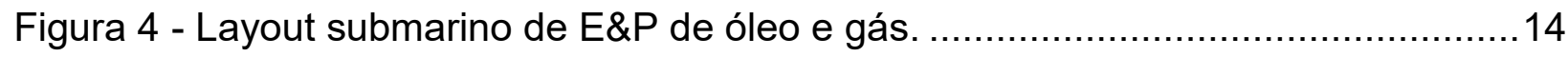

Figura 5 - Evolução do preço do barril de petróleo em dólares americanos..................16

Figura 6 - Projeção do preço do barril de petróleo. .................................................17

Figura 7 - Desenho 3D de uma válvula gaveta submarina manual. ............................19

Figura 8 - Válvulas gaveta submarinas atuadas FSC (esquerda) e FSO (direita).........20

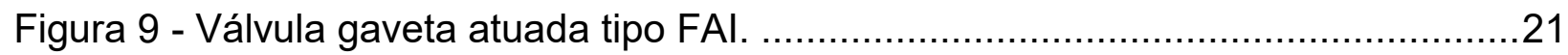

Figura 10 - Escoamento em uma válvula gaveta fechada.......................................21

Figura 11 - Gráfico Pressão x Tempo de abertura e fechamento de uma válvula gaveta

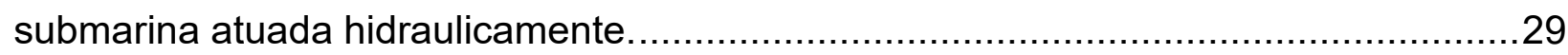

Figura 12 - Um ciclo de abertura e fechamento de uma válvula gaveta atuada .............31

Figura 13 - Gráfico llustrativo de Pressão e Temperatura ao longo do Teste ................37

Figura 14 - Desenho 2D: Parâmetros principais de um olhal de içamento .....................43

Figura 15 - Desenho 3D da câmara de teste com a válvula posicionada......................44

Figura 16 - Desenho 3D da estrutura de aço da câmara de testes com isolamento

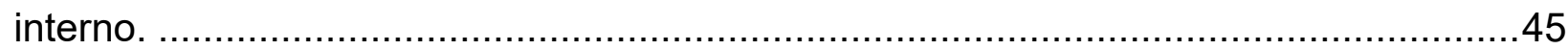

Figura 17 - Desenho 3D da estrutura de aço com isolamento interno..........................45

Figura 18 - Desenho detalhado da estrutura da câmara de testes..............................46

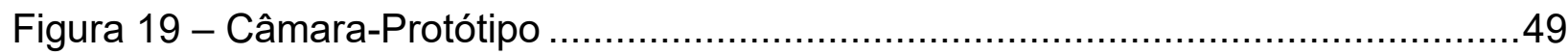

Figura 20 - Gráfico completo do teste de temperatra do protótipo …..........................50

Figura 21 - Gráfico do Aquecimento do corpo e do atuador no teste do protótipo ........51

Figura 22 - Gráfico do retorno à TAMB do corpo e do atuador no teste do protótipo.......52

Figura 23 - Gráfico do Resfriamento do corpo e do atuador no teste do protótipo .......53

Figura 24 - Aplicação do isolamento térmico Novostic $^{\mathrm{TM}}$ na parede interna .................55

Figura 25 - Bico difusor de gás nitrogênio e ar comprimido ......................................56

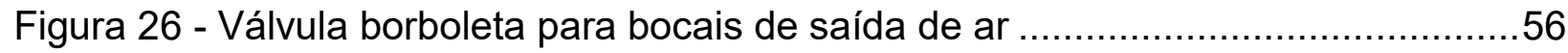

Figura 27 - Dispositivo de resfriamento/ volta para temperatura ambiente ..................56

Figura 28 - Esquemático das resistências na câmara de testes..................................57 


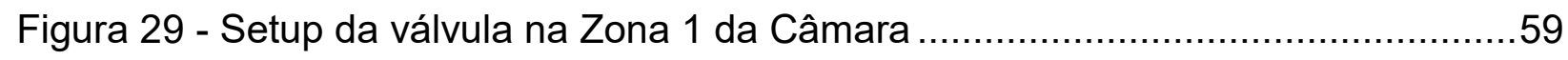

Figura 30 - Setup do Atuador na Zona 2 da Câmara................................................59

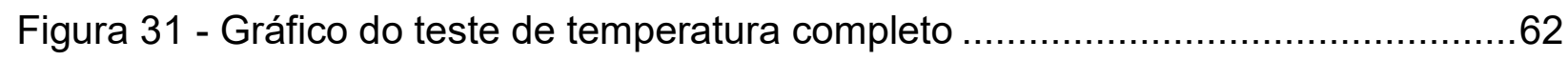

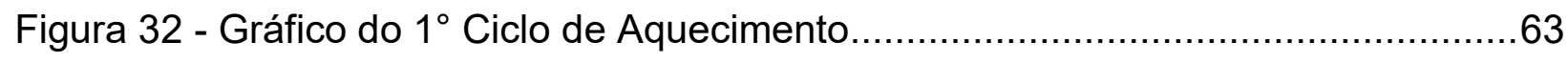

Figura 33 - Gráfico do $2^{\circ}$ Ciclo de Aquecimento....................................................64

Figura 34 - Gráfico do $3^{\circ}$ ciclo de aquecimento ....................................................66

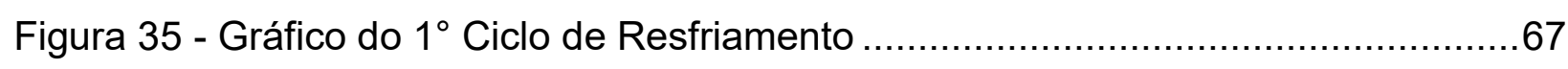

Figura 36 - Gráfico do $2^{\circ}$ ciclo de Resfriamento .....................................................68

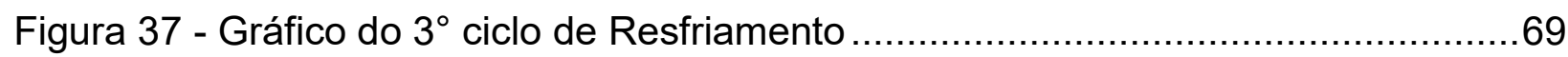




\section{Lista de tabelas}

Tabela 1 - Pressão de Trabalho de Válvulas Gaveta segundo norma API 6A. ...........24

Tabela 2 - Classificação de Temperatura de Trabalho API 6A..................................25

Tabela 3 - Tabela de Classificação do Material. ...................................................25

Tabela 4 - Tabela de Classificação PSL de Níveis da Qualidade...............................26

Tabela 5 - Itens para fabricação da câmara de testes........................................47

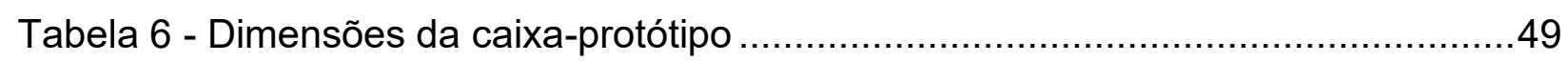

Tabela 7 - Dimensões externas da estrutura de madeira da câmara de testes ............55

Tabela 8 - Resultado do $1^{\circ}$ Ciclo de Aquecimento ..................................................64

Tabela 9 - Resultado do $2^{\circ}$ Ciclo de Aquecimento ................................................ 65

Tabela 10 - Resultado do $3^{\circ}$ Ciclo de Aquecimento ...........................................67

Tabela 11 - Resultado do $1^{\circ}$ Ciclo de Resfriamento ..........................................68

Tabela 12 - Resultado do $2^{\circ}$ Ciclo de Resfriamento .............................................69

Tabela 13 - Resultado do $3^{\circ}$ Ciclo de Resfriamento ................................................ 70 


\section{Introdução}

\subsection{Breve introdução à indústria de óleo e gás offshore}

O petróleo tem origem a partir da decomposição da matéria orgânica, como restos de animais, algas e plânctons que, após longo tempo sujeitos a condições especiais de temperatura e pressão, se transformam em hidrocarbonetos, mais conhecidos como óleo e gás. O ambiente marinho reúne perfeitamente essas condições e por isso a exploração offshore (fora da costa) se tornou uma das principais fontes de energia da matriz energética mundial. No final do século XIX, surgiam as primeiras plataformas offshore do ocidente. Foram descobertos campos de óleo na costa da Califórnia, o qual passou a ser extraído com simples plataformas montadas em piers de madeira que se estendiam da costa para o mar.

A partir de 1960, a indústria de óleo e gás começou a ser amplamente expandida e a perfuração offshore imensamente lucrativa. Juntamente com este acelerado crescimento econômico, começaram a surgir os primeiros grandes acidentes ambientais, causados em virtude de vazamentos de óleo. Em 1967, ocorreu um encalhe do petroleiro Torrey Canyon, que ocasionou o vazamento de 123000 toneladas de petróleo na costa da Inglaterra e da França (CASTRO, 2010). Em 1989, na costa do Alasca, ocorreu um dos acidentes ambientais mais graves da história mundial, o conhecido caso do navio petroleiro Exxon Valdez, que provocou o derramamento de aproximadamente 42 milhões de litros de petróleo, com os impactos ambientais sendo sentidos até os dias de hoje. No mesmo ano, 1989, em Portugal, também ocorreu o derramamento de 30000 toneladas de petróleo pelo navio Aragón (PETERSON et al., 2003, p. 2082).

Os acidentes em campo são motivo para que os testes de qualificação dos equipamentos de exploração e produção (E\&P) de óleo e gás offshore sejam cada vez mais rigorosos. Os desafios de operação exigem da indústria um rigoroso controle da qualidade e alto nível de confiabilidade e segurança. Por isso, os testes de qualificação dos equipamentos utilizados na exploração e produção de óleo e gás offshore são executados sob normas que exigem alto nível de desempenho dos dispositivos como, por exemplo, as normas publicadas pelo API (Americam Petroleum Institute). 


\subsection{Principais equipamentos}

A Árvore de Natal Molhada (ANM), exemplificada na Figura 1, é um equipamento instalado na cabeça do poço submarino, composto por um conjunto de válvulas e conectores que garantem o controle do fluxo dos fluidos produzidos ou injetados no poço. Uma ANM é, geralmente, a primeira barreira do fluido de produção após sua saída do poço e é considerada o principal equipamento de segurança de um poço submarino, sendo por isso preferível utilizar válvulas gaveta atuadas que possuam o mecanismo de retorno por mola, como detalhado posteriormente neste documento. São projetadas para suportar elevadas pressões e temperaturas do poço, além de elevadas pressões e baixas temperaturas ambientes. Podem ser instaladas por mergulhadores em profundidade de até $300 \mathrm{~m}$ ou, quando em águas profundas e ultra-profundas, com auxílio de um veículo de operação remota (Remotely Operated Vehicle - ROV). São basicamente compostas de um bloco principal, fabricado em aço forjado, que possui dois diâmetros de passagem, ("passagem de produção" e a "passagem de anular") e são nestas passagens que estão instaladas válvulas gaveta atuadas.

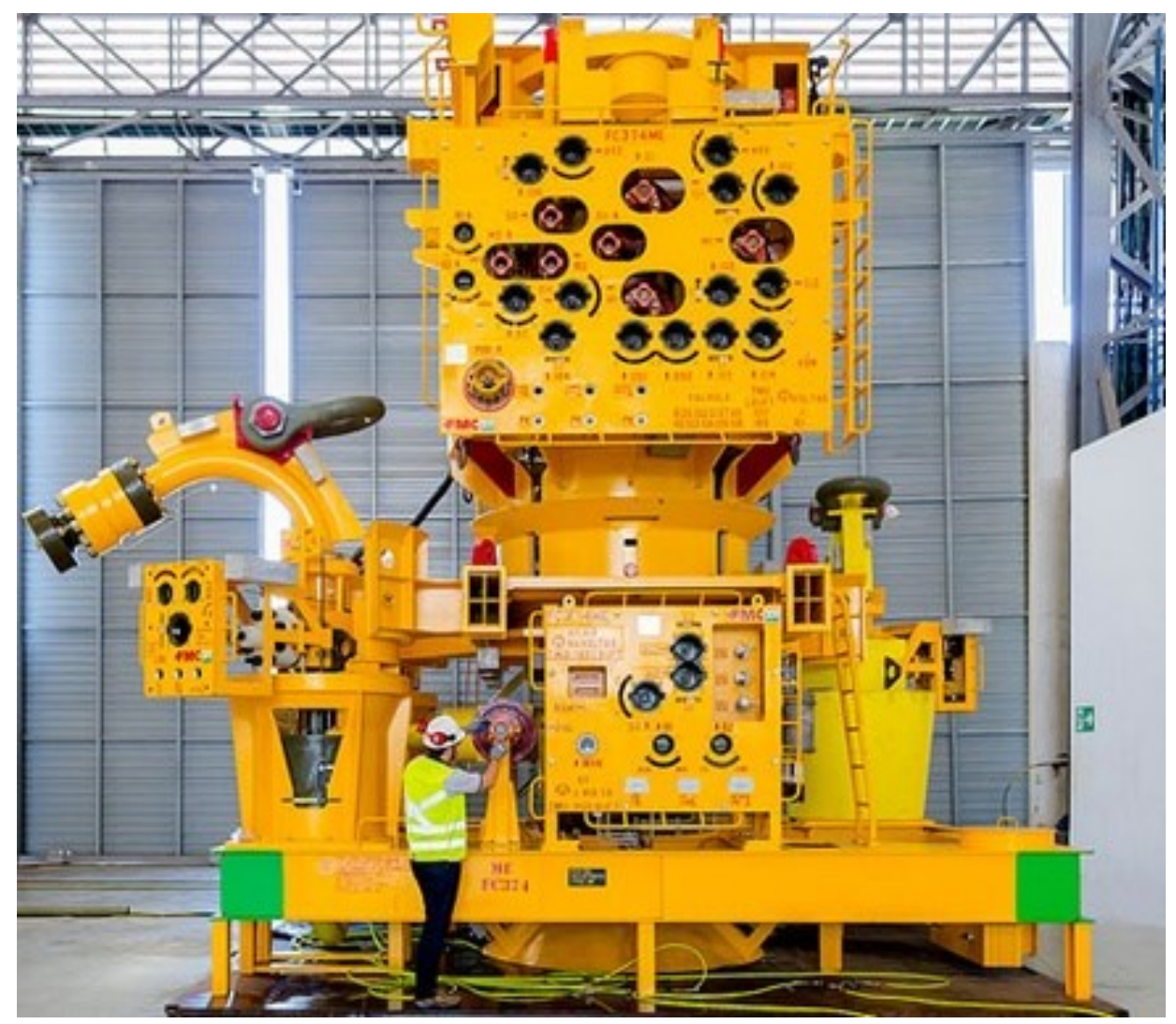

Figura 1 - Árvore de natal molhada. 
As linhas flexiveis são os dutos que conduzem os fluidos produzidos ou injetados no poço, podendo levar o fluido para as unidades de produção ou para um equipamento da planta submarina (uma árvore de natal molhada ou um manifold).

Risers, flexíveis (Figura 2) ou rígidos, são os dutos que levam os fluidos de uma ANM ou manifold à plataforma.

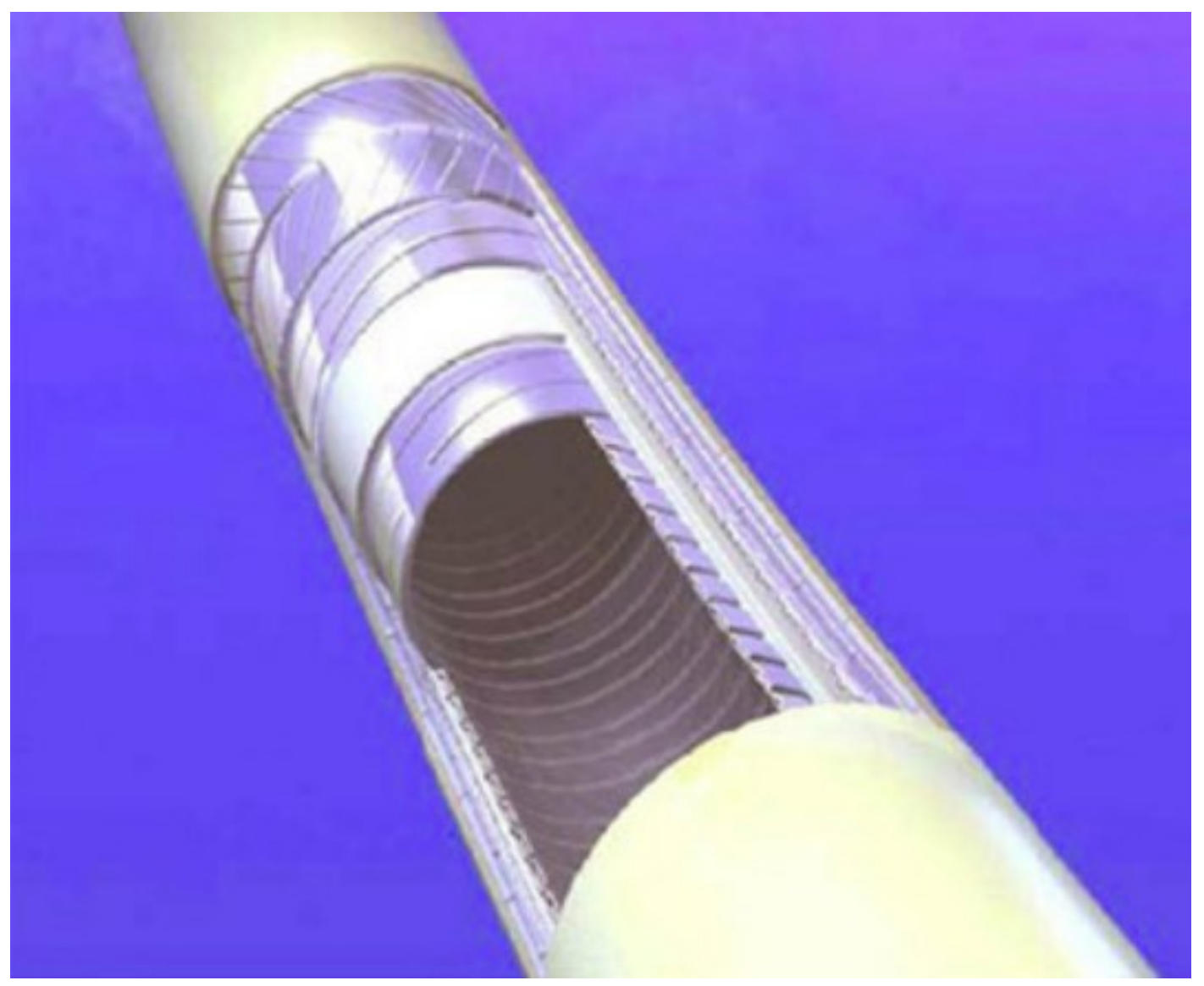

Figura 2 - Riser flexível.

Já os Manifolds, como o ilustrado na Figura 3, são equipamentos constituídos por válvulas, tubulações e acessórios que permitem o direcionamento da produção de vários poços às unidades de produção e também possibilitam a distribuição de linhas de injeção de água e gás-lift, permitindo que um grupo de poços compartilhem sistemas de injeção de água e gás-lift. Como concentram as linhas de fluidos conectadas aos poços, os manifolds ajudam a reduzir o número de risers conectados à plataforma, além de reduzir o comprimento total das linhas de interligação de poços usados em um sistema de produção. Conjugam a produção de dois ou mais poços. 


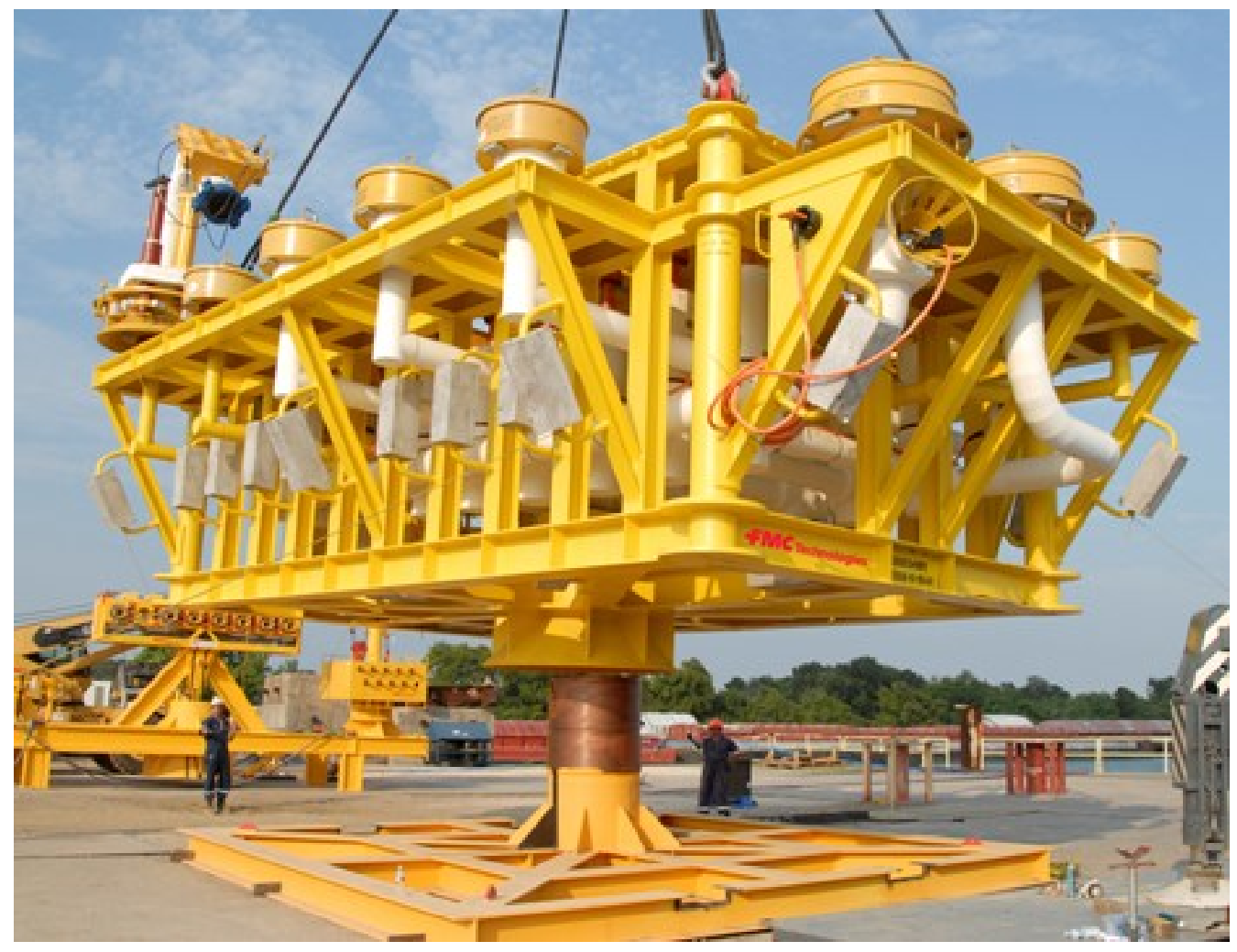

Figura 3 - Manifold submarino.

$\mathrm{Na}$ imagem abaixo está representado um layout submarino de E\&P, com manifolds, ANMs, linhas fexíveis e os risers ligados às plataformas na superfície. Para que esta planta opere em segurança e corretamente, durante a fase de projeto, cada um dos

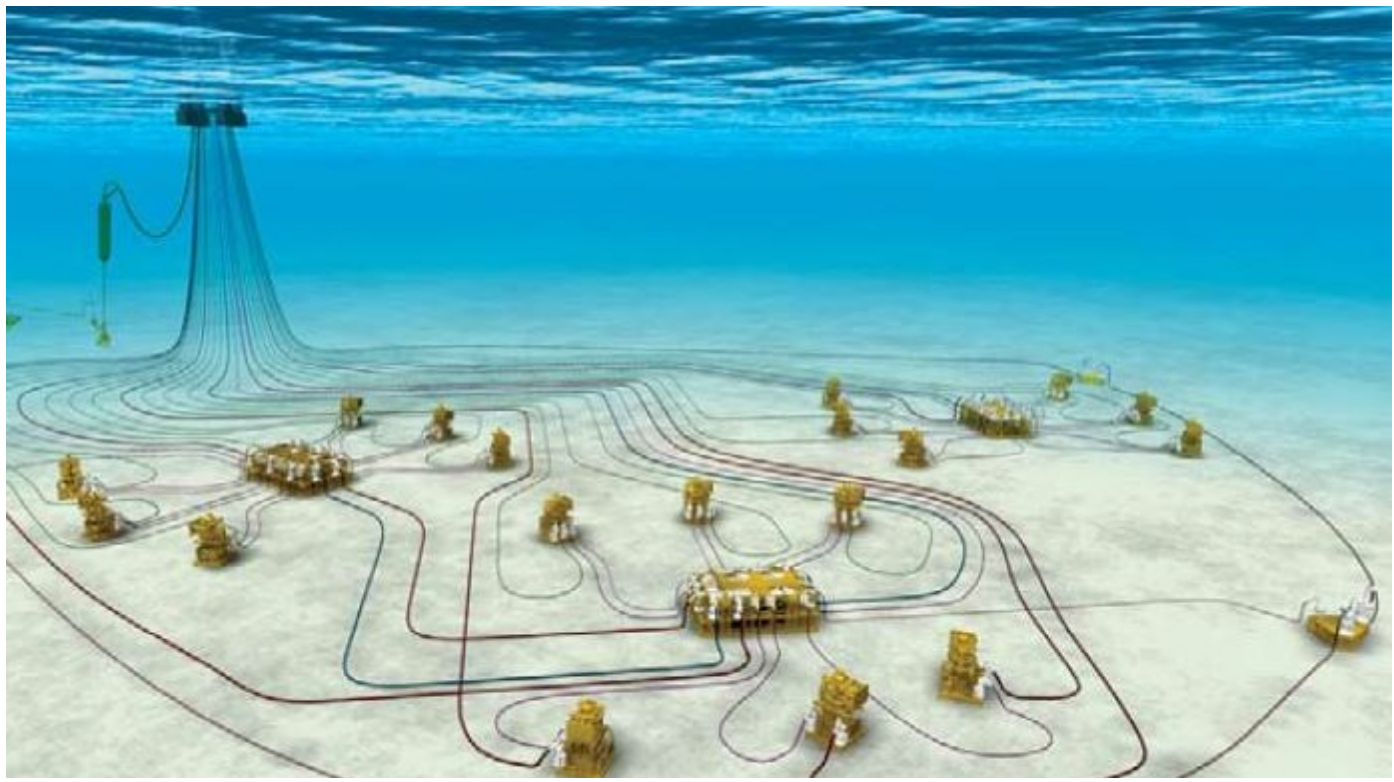

Figura 4 - Layout submarino de E\&P de óleo e gás. 
equipamentos deve ser projetado sob normas técnicas rigorosas para assegurar confiabilidade à operação.

\subsection{Normas e Testes de Qualificação}

Conforme apresentado na seção anterior, a extração de óleo e gás offshore é um processo extremamente complexo, caro e que envolve uma série de riscos. Desta forma, todas as etapas da engenharia do projeto, desde a definição dos parâmetros até as especificações dos dispositivos de testes, devem estar de acordo com normas técnicas. Sendo assim, surge a necessidade de haver entidades responsáveis pela elaboração dessas normas e entidades de fiscalização do cumprimento das mesmas (inspeção de terceira parte). As entidades que regulam e normatizam os equipamentos E\&P offshore mais relevantes para este projeto são:

- American Petroleum Institute (API): Associação comercial norte americana que representa cerca de 400 empresas envolvidas nas fases de extração, refino e distribuição de petróleo;

- International Organisation for Standardization (ISO): Rede formada por organismos de regulamentação de 162 países, com sede em Genebra (Suíça);

- Petróleo Brasileiro S.A. (Petrobras - Especificações Técnicas - ETs): Empresa brasileira de capital misto responsável pelo controle e exploração da maior parte das jazidas de petróleo em território nacional. Esta empresa se destaca das demais por estar na vanguarda das pesquisas em extração de petróleo em águas ultraprofundas. Por ser a maior compradora de equipamentos de E\&P offshore do país, a Petrobras estabelece algumas das suas próprias normas para certas etapas de seus projetos, que devem ser seguidas por todos os seus fornecedores de equipamentos E\&P. Vale ressaltar que essas ETs são baseadas em padrões internacionais como API e ISO.

A norma API 6-A, além de definir normas técnicas para projeto, matéria prima, fabricação e montagem, também define o processo de testes de qualificação (Performance Verification Test - PVT) dos equipamentos a serem utilizados. 
Durante esse processo de homologação, o dispositivo (por exemplo uma válvula, um anel de vedação, um conector) é testado à pressão, temperatura e lâmina d'água máxima de trabalho. O equipamento a ser qualificado é "ciclado" diversas vezes em todas essas condições e é desmontado ao final para verificar se houve danos em componentes críticos. Uma vez que este teve seu desempenho e integridade comprovados, sua qualificação está aprovada e este dispositivo pode ser fabricado para utilização em campo. Todas as novas válvulas submarinas devem passar por testes para comprovar o desempenho e integridade e, só então, podem ser autorizadas para uso.

\subsection{Cenário atual do mercado}

O excesso de oferta de petróleo, somado aos acontecimentos no cenário político nacional e internacional na segunda metade de 2014, causou uma grande queda nos preços do petróleo no mercado internacional, como pode ser visto no gráfico da Figura 5.

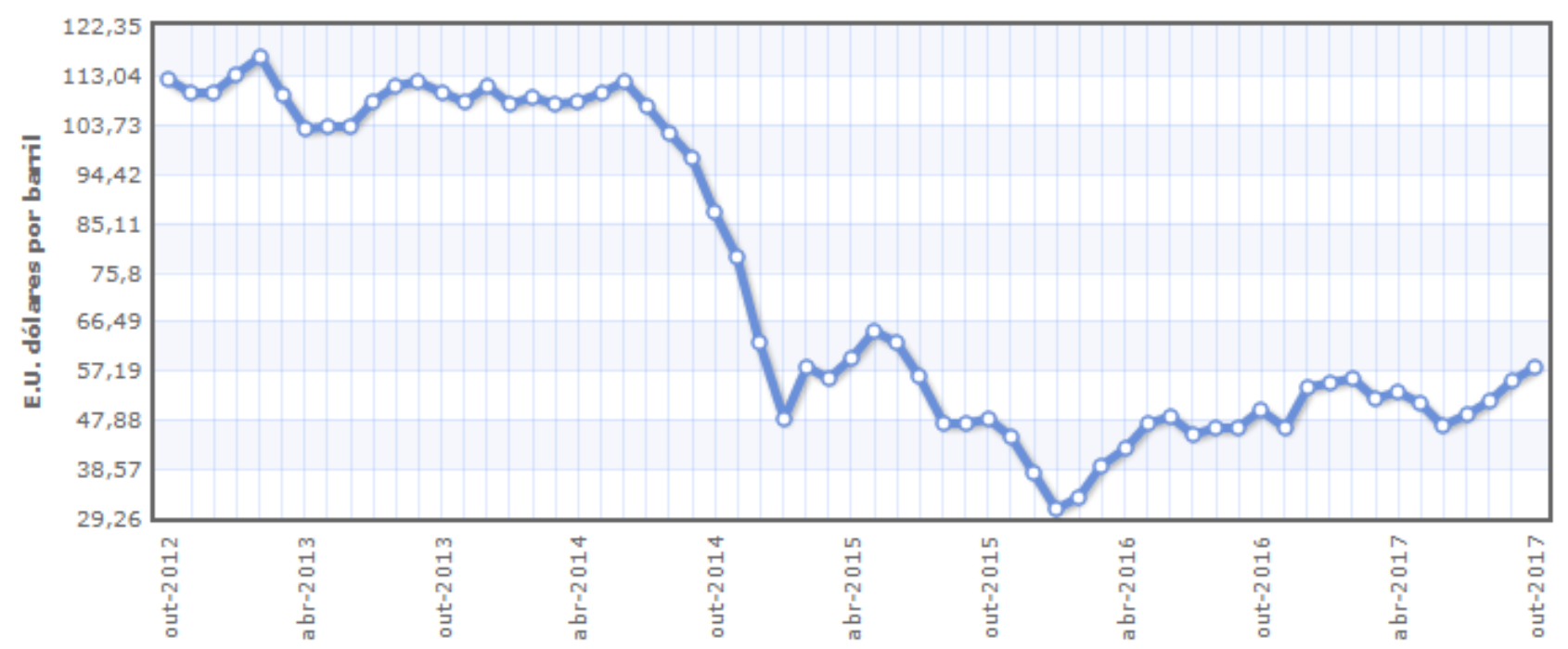

Figura 5 - Evolução do preço do barril de petróleo em dólares americanos.

Essa crise na indústria de óleo e gás forçou o mercado a se adaptar rapidamente às mudanças. Antes da crise, o mercado era impulsionado, principalmente, pela oferta, e por isso todos os esforços se concentravam na produção. Agora, a indústria se concentra na otimização de recursos para se tornar mais eficiente e reduzir custos, 
principalmente, operacionais. Com este fim, estudos de otimização de processos e produção foram feitos por todas as grandes empresas do setor.

No Centro de Pesquisa e Tecnologia da TechnipFMC, foi feito um importante estudo em mapeamento de fluxo de processos, visando principalmente reduzir tempos de execução e otimizar fluxos dos processos mais críticos.

Este Projeto de Gradução insere-se nos esforços de adaptação da empresa ao novo mercado e visa otimizar um dos testes de qualificação de um dos principais equipamentos produzidos pela TechnipFMC. Com iniciativas como esta, a indústria de óleo e gás no Brasil demonstrou força de reação a cenários desfavoráveis. Somando isso às projeções do preço do barril de petróleo dos investidores, conforme apresentado na Figura 6, o mercado de óleo e gás offshore pode voltar a crescer em breve.

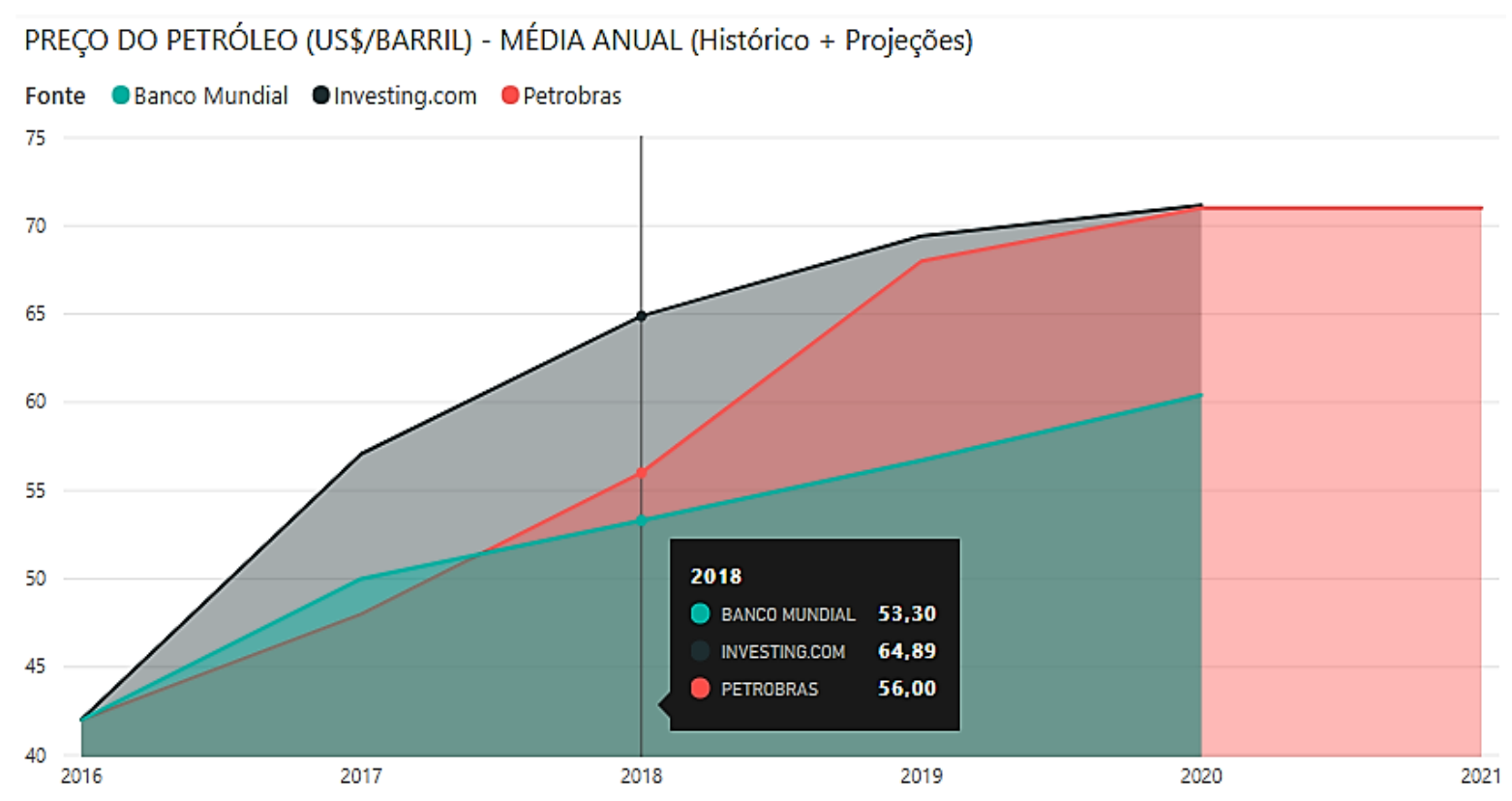

Figura 6 - Projeção do preço do barril de petróleo.

\subsection{Objetivo}

Este Projeto de Graduação apresenta o desenvolvimento de uma câmara térmica para teste de temperatura dual zone de qualificação de válvulas gaveta submarinas atuadas, conforme norma API 6A Apêndice F.

Será inicialmente apresentada uma introdução sobre projeto de válvulas gavetas submarinas atuadas segundo a norma API 6A, e seus testes de qualificação. 0 teste 
de temperatura foi estudado detalhadamente para que todos os requisitos da câmara de testes fossem mapeados e o projeto pudesse ser detalhado. Assim, foi construído e testado um protótipo para validar a concepção do projeto da câmara de testes. Após análise dos resultados do teste com o protótipo, o projeto foi fabricado, montado e testado. A partir destes resultados será possível concluir se os objetivos do projeto foram alcançados.

\section{Válvula Gaveta Submarina Atuada}

\subsection{Válvula Gaveta}

Válvulas gaveta são caracterizadas por possuírem uma gaveta como elemento de bloqueio de vazão. São vantajosas para bloqueio ou abertura total do fluxo, com a gaveta se movimentando linearmente em um curso proporcional ao tamanho nominal de sua passagem. Os modelos do tipo gaveta são as válvulas de bloqueio de maior utilização na indústria, sendo as mais eficientes e simples para o escoamento de fluidos sob altas pressões e temperaturas (MATHIAS, 2014).

As válvulas gaveta podem ser divididas em dois tipos: manual ou hidráulica. A válvula manual, ilustrada na Figura 7, ao ser girada, transmite movimento de torque ao obturador, que se movimenta linearmente, subindo ou descendo. Essa atuação se dá através de uma interface em forma de haste. As válvulas gaveta submarinas manuais, dependendo da lâmina d'água de operação, só podem ser atuadas por um veículo operado remotamente (ROV - remotely operated vehicle). Em águas rasas, até 300 m, a atuação pode ser feita por um mergulhador. 


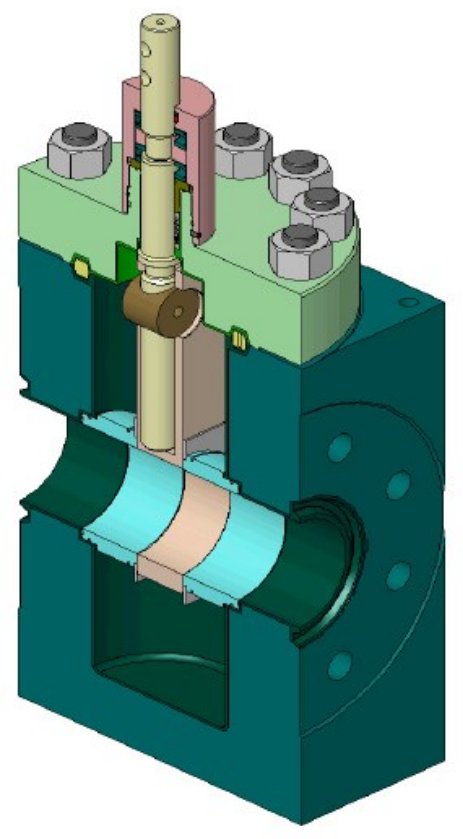

Figura 7 - Desenho 3D de uma válvula gaveta submarina manual.

O outro tipo de válvula gaveta possui um atuador, geralmente hidráulico, que pode ser acionado remotamente da plataforma ou de uma unidade flutuante de armazenamento e transferência (Floating Production Storage and Offloading FPSO). Elas podem ser subdividas quanto a sua posição final em caso de falha na operação hidráulica. Em caso de perda de controle pode ser desejável que a válvula bloqueie o fluxo ou libere-o totalmente, sendo as alternativas chamadas de falhafecha (fail safe close - FSC) ou falha-abre (fail safe open - FSO), ilustradas na Figura 8. Se for desejável que a válvula continue como está no momento da falha, a válvula atuada é classificada como falha como está (fail as is - FAl), ), apresentada na Figura 9. 

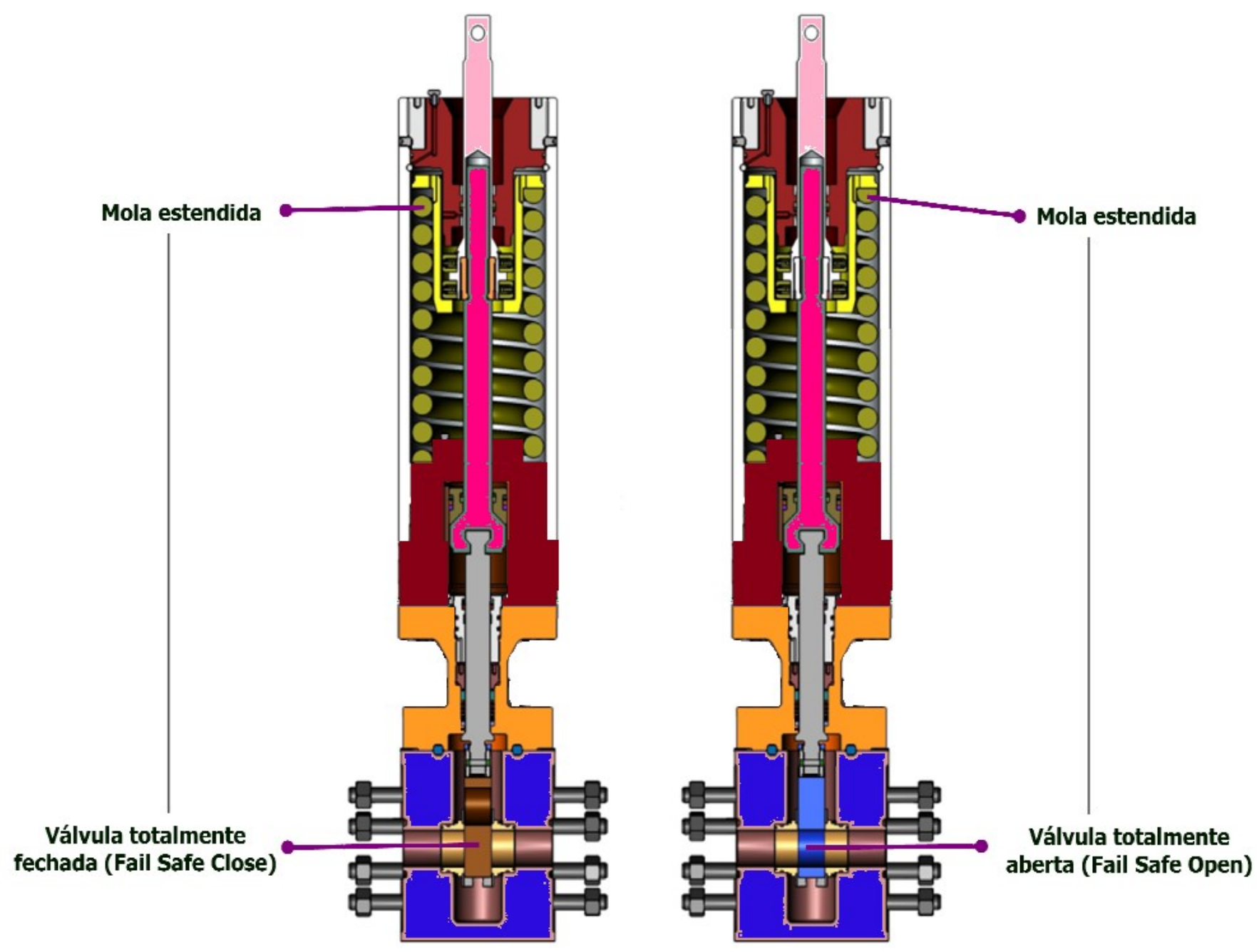

Figura 8 - Válvulas gaveta submarinas atuadas FSC (esquerda) e FSO (direita). 


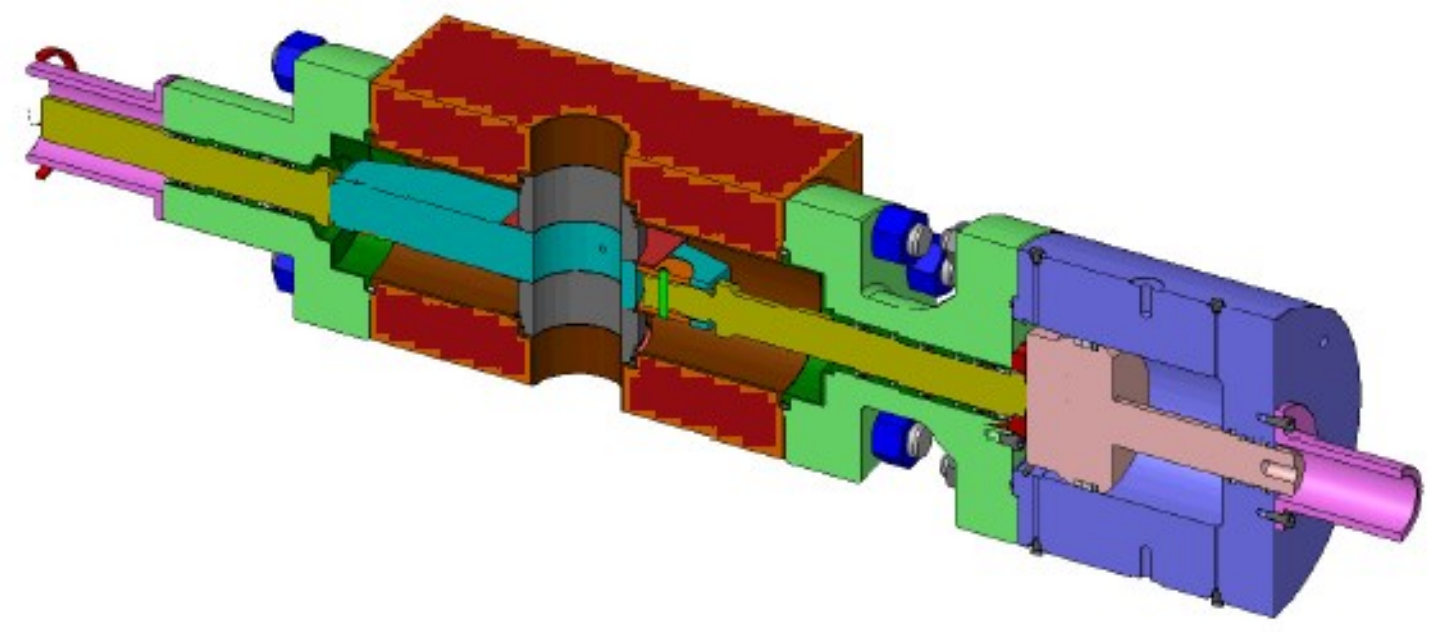

Figura 9 - Válvula gaveta atuada tipo FAI.

O retorno à posição de falha das válvulas FSO e FSC se dá por uma mola. As válvulas gaveta são constituídas por:

- Sede - elemento principal que faz a vedação entre a montante e o corpo, pois possui uma vedação elastomérica em sua interface com o alojamento no corpo. Quando a válvula é pressurizada, a sede é projetada contra a gaveta, aumentando a pressão de contato entre as interfaces, melhorando a vedação conforme pode ser visualizado na Figura 10.

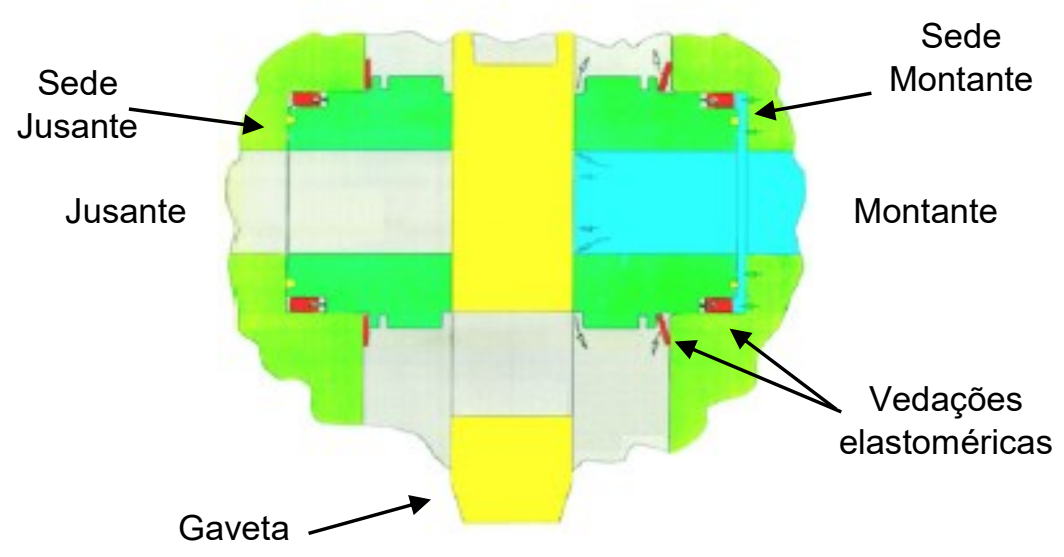

Figura 10 - Escoamento em uma válvula gaveta fechada. 
- Gaveta - elemento principal de bloqueio que interrompe o fluxo entre as regiões a montante e a jusante. Emprega-se uma vedação do tipo metalmetal com as sedes dos dois lados;

- Corpo - responsável por conter a pressão da linha e fazer a ligação da válvula à tubulação;

- Bonnet - elemento de ligação entre o corpo e o atuador da válvula gaveta. Em um lado ele é fixo ao corpo por meio de porcas e estojos, e a vedação entre essas interfaces é realizada por meio de um anel metálico, que veda impedindo a penetração do fluido externo à válvula. No outro lado, ele é fixo no atuador da mesma forma, mas a vedação entre essas interfaces é do tipo elastomérica;

- Gaxetamento do bonnet - elemento responsável por ser a primeira barreira de contenção da pressão do fluido de produção, garantindo que este não se misture com o fluido do pórtico de compensação da mola;

- Back-seat - é a região responsável pela vedação entre a haste e o bonnet, sendo considerada uma segunda barreira responsável por impedir a penetração do fluido de produção para dentro do atuador; e

- Haste e Haste média - elementos responsáveis por transmitir movimento linear sobre a gaveta, permitindo as ações de abertura e fechamento da válvula. A haste média é montada na haste superior (do atuador) e na haste ,que por sua vez é acoplada à gaveta.

O atuador é o responsável pelo movimento da gaveta, sendo basicamente composto por:

- Mola - é um dos elementos mais críticos de uma válvula atuada, sendo montada com uma pré-carga responsável por manter a válvula na posição e garantir seu retorno em caso de falha, para a posição totalmente fechada, se FSC, ou totalmente aberta, se FSO;

- Pistão - acionado hidraulicamente;

- Flanges adaptadores em suas extremidades;

- Hastes de transmissão de movimento à gaveta;

- Pórticos de pressurização; e 
- Câmara de compensação de pressão - torna o atuador insensível à influência da lâmina d'água (profundidade de operação).

Existem diversos modelos de atuadores para válvulas gaveta submarinas, sendo alguns muito semelhantes a outros. No entanto, o modelo M3000 se destaca na indústria de óleo e gás offshore brasileira.

A escolha do fluido de controle do atuador é importante para o projeto do mesmo, pois a densidade específica influi diretamente na pressão da coluna do fluido da linha de controle.

Os fluidos mais comumente utilizados para acionamento de funções hidráulicas em equipamentos submarinos são o HW-443 e o HW-525. Este parâmetro também deve ser pré-determinado pelo solicitante.

Este Projeto de Graduação baseou-se em uma válvula gaveta atuada do modelo M132-AH700 fail-close, com as seguintes características:

- Diâmetro nominal da passagem de 130,17 mm (5 1/8");

- Comprimento aproximado (com atuador): 2,00 metros;

- Massa aproximada (com atuador): 2 toneladas;

- Pressão de trabalho: $69 \mathrm{MPa}$ (10000 psi);

- Temperatura máxima de trabalho: $180^{\circ} \mathrm{C}$;

- Temperatura mínima de trabalho: $-18^{\circ} \mathrm{C}$;

Este modelo M132-AH700 é uma válvula gaveta atuada hidraulicamente projetada para uma ANM que tem como principal função direcionar os fluidos, sejam eles água, óleo ou gás. O atuador é do modelo M3000 e utiliza o fluido de controle HW443. 


\subsection{Requisitos Principais de Projeto}

No projeto de uma válvula gaveta submarina os requisitos principais do projeto devem garantir a funcionalidade e vida útil esperada do equipamento. Sendo assim, esses requisitos devem ser definidos de acordo com o fluido de operação ao qual a válvula será submetida.

Deve-se estudar as classes de materiais, de pressão e de temperatura, bem como os níveis de qualidade (Product Specification Levels - PSL) do equipamento. Todos esses requisitos são definidos pelo cliente.

A classe de pressão define a pressão máxima que o fluido atingirá a válvula regida pela norma API 6A, sendo a pressão máxima de trabalho conforme apresentado na Tabela 1.

Tabela 1 - Pressão de Trabalho de Válvulas Gaveta segundo norma API 6A.

\begin{tabular}{|c|c|c|}
\hline Classe & Pressão (psi) & Pressão (Mpa) \\
\hline 2000 & 2000 & 13,8 \\
\hline 3000 & 3000 & 20,7 \\
\hline 5000 & 5000 & 34,5 \\
\hline 10000 & 10000 & 69,0 \\
\hline 15000 & 15000 & 103,5 \\
\hline 20000 & 20000 & 138,0 \\
\hline
\end{tabular}

A classe de temperatura define um intervalo de temperatura à qual a válvula pode ser submetida durante a operação, conforme definido na Tabela 2. A temperatura máxima indica a temperatura que o fluido irá atingir a válvula e a temperatura mínima indica a mínima do ambiente externo da válvula. Válvulas submarinas são normalmente expostas a temperaturas externas de trabalho abaixo de zero graus Celsius. Definida a classe de temperatura, deve-se avaliar os materiais das peças e das vedações elastométricas. 
Tabela 2 - Classificação de Temperatura de Trabalho API 6A.

\begin{tabular}{|c|c|c|c|c|}
\hline Temperatura & $\operatorname{Min}\left({ }^{\circ} \mathrm{F}\right)$ & $\operatorname{Max}\left({ }^{\circ} \mathrm{F}\right)$ & $\operatorname{Min}\left({ }^{\circ} \mathbf{C}\right)$ & $\operatorname{Max}\left({ }^{\circ} \mathbf{C}\right)$ \\
\hline $\mathrm{K}$ & -75 & 180 & -60 & 82 \\
\hline $\mathrm{L}$ & -50 & 180 & -46 & 82 \\
\hline $\mathrm{P}$ & -20 & 180 & -29 & 82 \\
\hline $\mathrm{R}$ & $\mathrm{Amb}$ & $\mathrm{Amb}$ & $\mathrm{Amb}$ & $\mathrm{Amb}$ \\
\hline $\mathrm{S}$ & 0 & 150 & -18 & 66 \\
\hline $\mathrm{T}$ & 0 & 180 & -18 & 82 \\
\hline $\mathrm{U}$ & 0 & 250 & -18 & 121 \\
\hline $\mathrm{V}$ & 35 & 250 & 2 & 121 \\
\hline $\mathrm{X}$ & 0 & 350 & -18 & 180 \\
\hline $\mathrm{Y}$ & 0 & 650 & -18 & 345 \\
\hline
\end{tabular}

Além da temperatura à qual a válvula será submetida, a classe de material é definida pela corrosividade do fluido de operação da válvula. Deve ser realizada uma análise em laboratório do fluido proveniente do poço a fim de determinar sua composição química, como por exemplo porcentagem de $\mathrm{CO}_{2}, \mathrm{H}_{2} \mathrm{~S}$, pH e temperatura. A norma API 6A classifica os materiais conforme a Tabela 3.

Tabela 3 - Tabela de Classificação do Material.

\begin{tabular}{|c|c|c|}
\hline Classe do material & $\begin{array}{l}\text { Requisitos mínimos de } \\
\text { material para corpos, bonnets } \\
\text { e conexões de entrada e saída }\end{array}$ & $\begin{array}{c}\text { Requisitos mínimos para } \\
\text { peças sob pressão, hastes e } \\
\text { mandris de tubulação }\end{array}$ \\
\hline AA - Serviço Geral & Aço carbono ou aço baixa liga & Aço carbono ou aço baixa liga \\
\hline BB - Serviço Geral & Aço carbono ou aço baixa liga & Aço Inoxidável \\
\hline CC - Serviço Geral & Aço Inoxidável & Aço Inoxidável \\
\hline DD - Serviço corrosivo & Aço carbono ou aço baixa liga & Aço carbono ou aço baixa liga \\
\hline EE - Serviço corrosivo & Aço carbono ou aço baixa liga & Aço Inoxidável \\
\hline FF - Serviço corrosivo & Aço Inoxidável & Aço Inoxidável \\
\hline HH - Serviço corrosivo & $\begin{array}{l}\text { Liga resistente à corrosão } \\
\text { (CRA) }\end{array}$ & $\begin{array}{l}\text { Liga resistente à corrosão } \\
\text { (CRA) }\end{array}$ \\
\hline
\end{tabular}


O quarto, e não menos importante, requisito principal é a classificação por requisitos de nível da qualidade. Esta especificação depende apenas do cliente, que deve fazer uma análise de risco minuciosa e classificar o projeto como PSL1, PSL-2, PSL-3, PSL-3G ou PSL-4.

Estas classificações definem quais serão os tipos de inspeção das peças críticas durante a fabricação e teste de fábrica. Quanto maior o número, mais severo é o nível de inspeção das peças. Apenas os níveis PSL-3G e PSL-4 permitem trabalho com gás e por isso são expostos a testes mais severos, conforme definido na Tabela 4.

Tabela 4 - Tabela de Classificação PSL de Níveis da Qualidade.

\begin{tabular}{|c|c|c|c|}
\hline \multicolumn{4}{|r|}{ Níveis da Qualidade (PSL) } \\
\hline PSL & $\begin{array}{c}\text { Pressão } \\
\text { (Mpa) }\end{array}$ & $\begin{array}{c}\text { Pressão } \\
\text { (psi) }\end{array}$ & Inspeção \\
\hline PSL-1 & 34,5 & 5000 & $\begin{array}{l}\text { Ensaio de tração, impacto de dureza, inspeção dimensional e } \\
\text { visual. Pode ser soldado sem necessidade de teste adicional. }\end{array}$ \\
\hline PSL-2 & 103,5 & 15000 & $\begin{array}{c}\text { Todos os requisitos do PSL-1 e rastreabilidade dos componentes, } \\
\text { análises químicas, ensaios não destrutivos superficiais após } \\
\text { usinagem e soldagem. }\end{array}$ \\
\hline PSL-3 & $>103,5$ & $>15000$ & $\begin{array}{c}\text { Todos os requisitos do PSL-2 e ensaios não destrutivos } \\
\text { volumétricos do material (e.g. ensaio de dureza após reparo por } \\
\text { solda). }\end{array}$ \\
\hline $\begin{array}{c}\text { PSL- } \\
3 G\end{array}$ & $>103,5$ & $>15000$ & Todos os requisitos do PSL-3 e teste a gás severo. \\
\hline PSL-4 & $>103,5$ & $>15000$ & $\begin{array}{l}\text { Todos os requisitos do PSL-3G e requisitos adicionais que } \\
\text { dependerão da aplicação real do equipamento. }\end{array}$ \\
\hline
\end{tabular}




\subsection{Testes de Qualificação API 6A Apêndice F}

Os testes de qualificação têm como objetivo a verificação de possíveis falhas de projeto, desde o desenho técnico até a operação, possibilitando um levantamento de dados que ilustram o comportamento do equipamento que está sendo desenvolvido.

Para que essa atividade seja realizada de forma confiável, os procedimentos de testes, bem como os recursos utilizados para os testes, devem seguir normas técnicas rigorosas que visam garantir a qualidade dos resultados. Como uma válvula gaveta pode ser a primeira barreira do óleo que sai do poço para uma unidade de produção, garantir que o equipamento responda perfeitamente aos comandos durante a operação é o objetivo principal. A cada dia as regulamentações ambientais estão mais severas e as penalidades para acidentes ambientais tendem a aumentar. Com isso, a importância dos testes de qualificação cresce a cada novo projeto.

Segundo a norma internacional API-17D, para qualificação de uma válvula é preciso submetê-la a diversos testes de resistência, os chamados teste de verificação de desempenho (Performance Verification Testing - PVT), que são detalhados na norma API 6 A Apêndice F.

Essa verificação acontece submetendo a válvula a testes de desgaste acelerado, sob condições reais de operação em campo. Os testes de qualificação são feitos em uma válvula fabricada para a qualificação, e somente após a aprovação do desempenho são produzidos os equipamentos que serão entregues ao cliente, os quais são testados de forma objetiva e rápida, em um processo chamado Teste de Aceitação de Fábrica (Factory Acceptence Test - FAT). Este teste consiste em pressurizar a câmara do pistão gradualmente e verificar, por meio do gráfico gerado pelo programa de controle e monitoramento, os valores de pressão nos pontos críticos que serão apresentados mais à frente, sendo este teste também conhecido como teste de assinatura.

A norma API 6 A apêndice F é extensa e bem detalhada, havendo neste apêndice recomendações para a ordem de execução dos testes do procedimento para qualificação, mas cabe ao fabricante do equipamento a ser qualificado definir o procedimento de teste. Também é comum o cliente do equipamento solicitar testes 
adicionais. Os principais testes para qualificação de uma válvula gaveta submarina atuada hidraulicamente segundo a norma API 6A apêndice $F$ são:

1) Teste de vedação hidrostática da válvula;

2) Teste cíclico de torque (200 ciclos);

3) Teste cíclico de pressão (360 ciclos);

4) Teste de vedação a gás;

5) Teste de temperatura; e

6) Teste em câmara hiperbárica.

Esses seis testes coletam dados a respeito do desempenho, integridade e vedação da válvula. Buscam garantir que a válvula opere sob máxima e mínima (100 psi) pressão de trabalho, sendo capaz de vedar nessas duas condições com máximo e mínimo diferencial de pressão entre montante e jusante.

Eles são feitos à temperatura ambiente (room temperature), que corresponde ao intervalo de $4{ }^{\circ} \mathrm{C}$ a $50{ }^{\circ} \mathrm{C}$, exceto o teste de temperatura, que possui valores específicos de temperatura.

Os testes utilizam principalmente, painéis de assinatura de válvula, unidades hidráulicas e/ou a gás, conectadas a linhas de acumuladores de pressão (responsáveis por simular e manter a pressão diferencial à qual o corpo da válvula e a câmara do atuador são submetidos), bombas hidráulicas, manômetros, transdutores de pressão e de temperatura, conexões, tubings MP (média pressão) de 20000 psi, mangueiras, fluido hidráulico HW e software de controle conectado aos transdutores. Os testes são realizados dentro de cabines de teste especiais chumbadas no chão que suportam altas pressões em caso de explosão ou falha em conexões. O teste de vedação a gás é feito com gás nitrogênio e é o teste de vedação mais crítico já que o fluido é gasoso e, logo, o risco de vazamento é maior. O teste hiperbárico é realizado dentro de uma câmara hiperbárica de capacidade usualmente variável entre 3000 a 5000 psi, que simula a lâmina d'água de operação.

Finalmente, o teste de temperatura, objeto específico deste Projeto de Graduação, deve ser feito em uma câmara especial que possibilite ciclagem da válvula, submetendo-a à máxima e mínima temperatura de teste. 
Um ciclo de pressão de uma válvula gaveta submarina atuada pode ser descrito pelo gráfico apresentado na Figura 11.

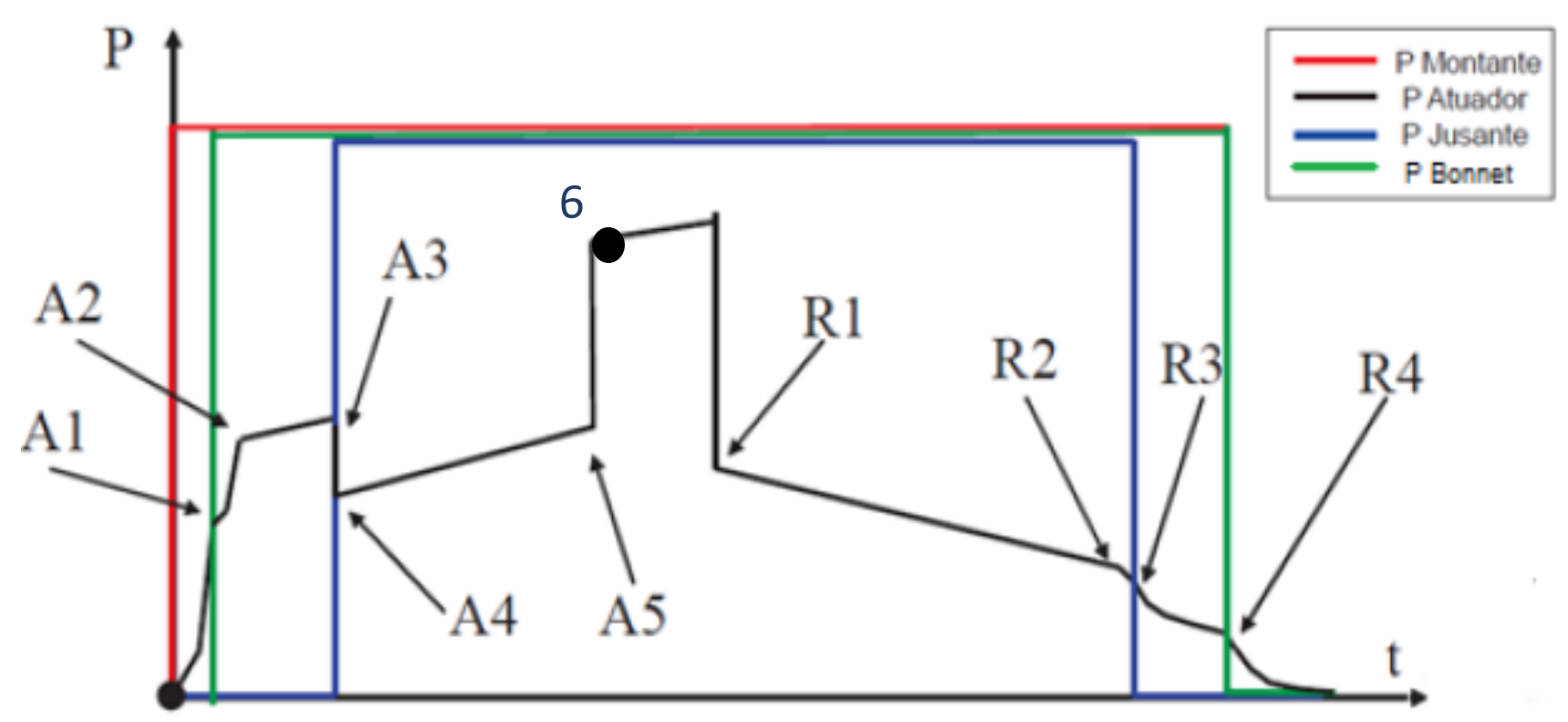

Figura 11 - Gráfico Pressão x Tempo de abertura e fechamento de uma válvula gaveta submarina atuada hidraulicamente.

Na Figura 11, podem-se identificar as seguintes etapas de pressurização:

1. A1 - Abertura do Back seat - É o ponto (a pressão) em que a haste superior inicia o movimento para dentro do atuador e se verifica aumento de pressão no pórtico de monitoramento do back seat;

2. A2 - Início do movimento da gaveta - ponto em que a gaveta sai da inércia e começa a se mover;

3. A3 - Antes do crack open - Há diferencial de pressão entre a montante e a jusante pois ainda não há passagem de fluido para a jusante (isto é, antes do crack open). Como o atuador trabalha contra a pressão da válvula, a sua pressão de operação irá aumentar até que a gaveta tenha se movido o suficiente para permitir passagem do fluido. Este ponto também é conhecido como crack open com diferencial de pressão;

4. A4 - Após crack open - Também conhecido como crack open sem diferencial de pressão, a montante e a jusante estão à mesma pressão (a do fluido); e 
5. A5 - Fim do movimento da gaveta - Ponto em que a gaveta e a haste superior chegam ao final de curso. Quando o atuador atinge o ponto 6 ele chegou em sua pressão máxima de acionamento.

Em seguida, tem-se a fase de despressurização do atuador:

6. R1 - Início do movimento de retorno da gaveta (R1) - ponto em que a pressão do atuador deve reduzir para que a gaveta (e logo a haste) inicie seu movimento;

7. $\mathbf{R 2}$ - Antes do estrangulamento (pinch-off) - ponto imediatamente antes do momento em que a montante e a jusante param de se comunicar. O diferencial de pressão ainda é zero entre a montante e a jusante;

8. R3 - Após o estrangulamento (pinch-off) - ponto logo após o momento que não há mais comunicação entre a montante e a jusante. Ponto em que o diferencial de pressão passa a ser diferente de zero; e

9. R4 - Vedação do back seat ou back pressure - ponto em que ocorre a queda de pressão devido à vedação metálica do back seat com o bonnet. A gaveta chega ao curso final de volta completando um ciclo de pressurização.

A cada teste, o programa de controle utilizado neste Projeto gera gráficos com as medições de pressão e de deslocamento linear da haste do atuador medido por um LVDT (Linear Variable Differential Transformer ou Transformador Diferencial Variável Linear). Na Figura 12 é possível visualizar um gráfico gerado no teste de ciclagem da válvula com um ciclo de abertura e fechamento completo. Nota-se que o programa marca os pontos principais automaticamente. 


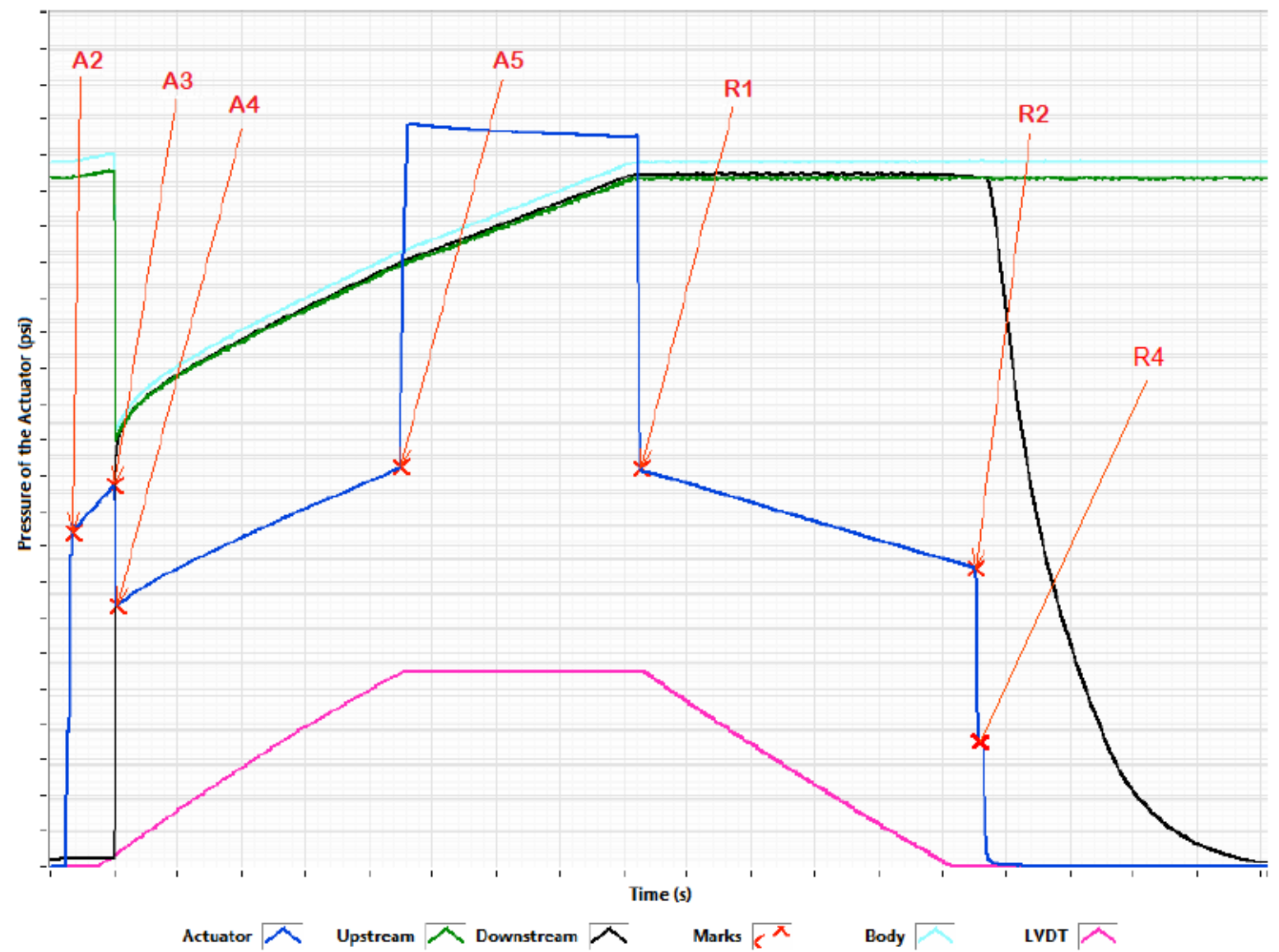

Figura 12 - Um ciclo de abertura e fechamento de uma válvula gaveta atuada

De todos os pontos apresentados acima, o que deve ser observado com mais criticidade é o back pressure. Se o valor encontrado no teste for muito baixo, significa que foi necessário que a câmara do pistão fosse despressurizada mais do que o necessário para que a mola pudesse retornar o conjunto do atuador ao seu local inicial.

Os critérios de aceitação dos resultados de cada teste são complexos e exigem análises cautelosas, no entanto pode ser verificado rapidamente por meio dos gráficos gerados se algum valor de pressão está acima do estipulado pela pressão máxima que o cliente especificou que a válvula trabalhará no campo. Havendo algum valor acima da pressão máxima admitida, a válvula estará reprovada. 


\section{Teste de Temperatura Dual Zone}

Conforme a norma API 6A apêndice $F$, o equipamento deve ser projetado para operar em uma ou mais temperaturas especificadas pela norma, conforme já foi discutido na seção 2.2. A temperatura máxima deve ser a temperatura do fluido de trabalho do equipamento e a temperatura mínima deve ser a do ambiente externo, em torno do equipamento. A tabela 2 (seção 2.1) indica as temperaturas definidas pela norma API 6 A.

De acordo com a classificação de temperatura do equipamento em projeto, a válvula a ser qualificada é de classe $X$, pois estará em ambiente de águas profundas, podendo chegar a temperaturas de $-18{ }^{\circ} \mathrm{C}$; além disso, o óleo que chega à válvula pode sair do poço com temperaturas muito altas como $180^{\circ} \mathrm{C}$. Logo, a válvula será submetida a ciclos de testes a temperaturas entre $-18{ }^{\circ} \mathrm{C} \mathrm{e}$ $180^{\circ} \mathrm{C}$.

O teste deste projeto é dual zone, isto é, a câmara de teste deve ter uma divisão de modo a criar duas zonas com temperaturas controladas independentemente, uma com o corpo da válvula (zona 1) e outra com o atuador (zona 2).

O projeto do atuador desta válvula especifica que o mesmo deve ser submetido a variações de temperatura entre $0{ }^{\circ} \mathrm{C} \mathrm{e} 70^{\circ} \mathrm{C}$. Enquanto a temperatura do corpo da válvula deve estar a $180^{\circ} \mathrm{C}$, a do atuador deve estar a $70^{\circ} \mathrm{C}$; e, analogamente, enquanto a válvula estiver a $-18^{\circ} \mathrm{C}$, o atuador deve estar a $0^{\circ} \mathrm{C}$, conforme indicado na Tabela 5.

Tabela 5: Temperaturas do teste dual zone a ser realizado

\begin{tabular}{|c|c|c|}
\hline & $\operatorname{T}_{\operatorname{MÁX}}\left({ }^{\circ} \mathrm{C}\right)$ & $\mathrm{T}_{\text {MIN }}\left({ }^{\circ} \mathrm{C}\right)$ \\
\hline Corpo $(V G)$ & 180 & -18 \\
\hline Atuador & 70 & 0 \\
\hline
\end{tabular}




\subsection{Transferência de calor}

A transferência de calor pode ser entendida como o movimento de energia provocado por um diferencial de temperatura, se dando em função de três mecanismos básicos: radiação, convecção e condução.

Radiação é a troca de calor na qual não acontece um contato direto entre a fonte de calor e o objeto a ser aquecido. A energia em forma de calor do campo de radiação é transportada por ondas eletromagnéticas na faixa do infravermelho, desta maneira não necessitando de um meio material. A convecção é o processo que ocorre quando existe o contato entre um fluido em movimento e uma superfície. Finalmente, a condução é a forma de transmissão de calor por contato entre as moléculas.

Para este Projeto de Graduação não serão feitas contas teóricas de transferência de calor, pois existem muitos parâmetros com grande complexidade para cálculo com exatidão, como por exemplo o quanto de calor a válvula absorve da resistência e o quanto é dissipado, quanto calor a válvula e o atuador perdem por minuto durante a pressurização a baixa e a alta temperaturas, altas e baixas pressões na linha.

Este é um projeto de engenharia em que testes empíricos são mais econômicos e produzirão resultados melhores que uma análise teórica. Por isso, foi decidido prototipar diretamente a solução que será apresentada mais à frente.

\subsection{Requisitos e recursos necessários}

Na norma API 6A apêndice $F$, além dos requisitos comentados na seção 2.2, existe uma subdivisão de Requisitos de Desempenho (Performance Requirements - PR) para os testes de temperatura, sendo estes parâmetros aceitáveis pela indústria, funcionando como uma garantia da qualidade e durabilidade esperada pelo produto.

A válvula considerada neste Projeto deverá passará por testes PR-2 em que são exigidos mais ciclos de abertura e fechamento que os testes PR-1.

Dados os requisitos principais do teste, temperaturas máximas e mínimas dos equipamentos a serem qualificados, é preciso especificar as temperaturas das zonas 1 e 2 para que a câmara de testes possa ser projetada. 
Para que o exterior da válvula não seja submetido a temperaturas muito superiores a $180{ }^{\circ} \mathrm{C}$, é recomendado que o ambiente externo do equipamento não alcance temperaturas máximas e mínimas muito além dos limites dos testes, por isso, será considerado, para especificação do isolamento, que a temperatura máxima da câmara será de aproximadamente $250{ }^{\circ} \mathrm{C}$ e a temperatura mínima $-80^{\circ} \mathrm{C}$. Esse intervalo, além de atender aos requisitos do material da válvula a ser testada, inclui um fator de segurança que elimina riscos de falhas microestruturais que possam ser causadas durante os testes, como por exemplo a iniciação e propagação de uma trinca.

Todo o controle e monitoramento do teste é automatizado e realizado por um software utilizando 8 RTDs do tipo Pt100 (quatro em cada zona, três de controle e um de monitoramento)) conectados a um painel de temperatura e este a um computador de teste.

A lógica do programa de controle trabalha independentemente em cada zona, buscando atingir uma temperatura alvo previamente definida, alinhando-a à média dos três RTDs de controle. Quando uma certa diferença pré-determinada entre esses valores é atingida, o técnico do teste muda a temperatura alvo para um valor previamente definido pelos engenheiros do teste. Além dos materiais necessários para a automatização do controle e monitoramento, outros recursos necessários são:

1. Câmara de teste dual zone com isolamento térmico;

2. Resistências elétricas de $40 \Omega$ aproximadamente;

3. Alimentação de gás nitrogênio de ar comprimido (3000 psi);

4. Dispositivos de resfriamentos com bicos injetores de gás nitrogênio $\left(\mathrm{N}_{2}\right)$;

5. Tubings MP para alimentação da válvula e do atuador;

6. Unidades Hidráulicas e Acumuladores; e

7. Suportes para válvula e atuador.

\subsection{Procedimento de Teste}

Primeiramente é montado o setup do teste. Para isso é preciso:

$1^{\circ}$. Içar a câmara de teste para dentro da Cabine de Testes com Pressão;

$2^{\circ}$. Colocar o suporte da válvula e atuador dentro da câmara térmica; 
$3^{\circ}$. Montar as resistências elétricas em torno da válvula e do atuador;

$4^{\circ}$. Assentar a válvula e atuador nos suportes;

$5^{\circ}$. Montar a placa bipartida de isolamento térmico que divide as zonas 1 e 2 ;

$6^{\circ}$. Conectar a linha de alimentação do atuador e da válvula nos devidos pórticos de pressurização e unidades hidráulicas/ acumuladores

$7^{\circ}$. Fixar os transdutores de pressão e de temperatura nos locais indicados pelo projeto e conectá-los ao sistema de aquisição de dados;

$8^{\circ}$. Fechar as tampas e montar osdispositivos de resfriamento de $\mathrm{N}_{2}$ nas tampas da câmara; e

$9^{\circ}$. Fechar e travar porta da Cabine de Teste com pressão.

A pressão de teste deste projeto é 10000 psi, e isto quer dizer que, quando houver pressão de 10000 psi a montante, a jusante deve haver uma pressão menor que 100 psi ( $1 \%$ da pressão de teste). A pressão deve sempre ser aplicada em degraus de 1000 psi por minuto. As etapas de hold pressure, (manter a pressão aplicada a montante) devem sempre ter no mínimo 60 minutos de duração.

Conforme descrito na seção 2.3, um ciclo é o processo de abertura e fechamento da válvula quando pressurizada. A norma API 6A não define um número máximo de ciclos para cada etapa, no entanto, para ser considerada qualificação PR-2 é exigido um mínimo de 20 ciclos a temperaturas máximas e 20 a temperaturas mínimas.

A válvula e o atuador devem estar à temperatura ambiente e pressão atmosférica para o início do teste.

Considera-se a temperatura estável quando as variações são menores que $0,5^{\circ} \mathrm{C}$ por minuto, considerando as temperaturas $T_{\text {MAX }}$ e $T_{\text {MiN }}$ definidas na Tabela 5.

O procedimento a seguir descreve as etapas do teste de temperatura sob a norma API 6A Apêndice F:

a) Aquecer o conjunto a $T_{M A X}$;

b) Aplicar pressão de teste (10000 psi) a montante. Manter esta pressão e temperatura por 60 minutos e então despressurizar o conjunto, início do ciclo de abertura da válvula (seção 2.3);

c) Resfriar o conjunto a TMiN; 
d) Aplicar pressão de teste a montante. Manter esta pressão e temperatura por 60 minutos e então despressurizar o conjunto.

e) Aquecer o conjunto à temperatura ambiente;

f) Aplicar $50 \%$ a $100 \%$ da pressão de teste (10000 psi) enquanto o conjunto é aquecido a $\mathrm{T}_{\mathrm{MAX}}$

g) Manter a pressão de teste e TMAX por no mínimo 60 minutos;

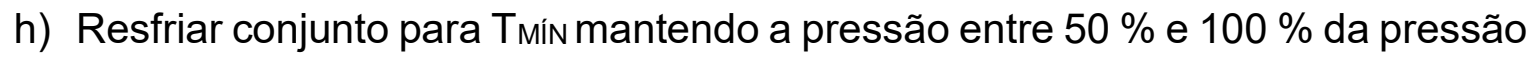
de teste;

i) Manter a pressão de teste e TMín por no mínimo 60 minutos;

j) Aquecer o conjunto para temperatura ambiente mantendo a pressão entre $50 \%$ e $100 \%$ da pressão de teste;

k) Despressurizar e aquecer o conjunto a $T_{M A X}$;

I) Aplicar pressão de teste (10000 psi) a montante. Manter esta pressão e temperatura por 60 minutos e então despressurizar o conjunto;

m) Resfriar o conjunto a TMíN;

n) Aplicar pressão de teste (10000 psi) a montante. Manter esta pressão e temperatura por 60 minutos e então despressurizar o conjunto;

o) Aquecer o conjunto à temperatura ambiente;

p) Aplicar pressão de teste (10000 psi) a montante. Manter esta pressão e temperatura por 60 minutos e então despressurizar o conjunto; e

q) Aplicar $5 \%$ a $10 \%$ da pressão de teste (10000 psi), manter por 60 minutos e por fim, despressurizar o conjunto; 
A Figura 13 representa as etapas descritas acima.

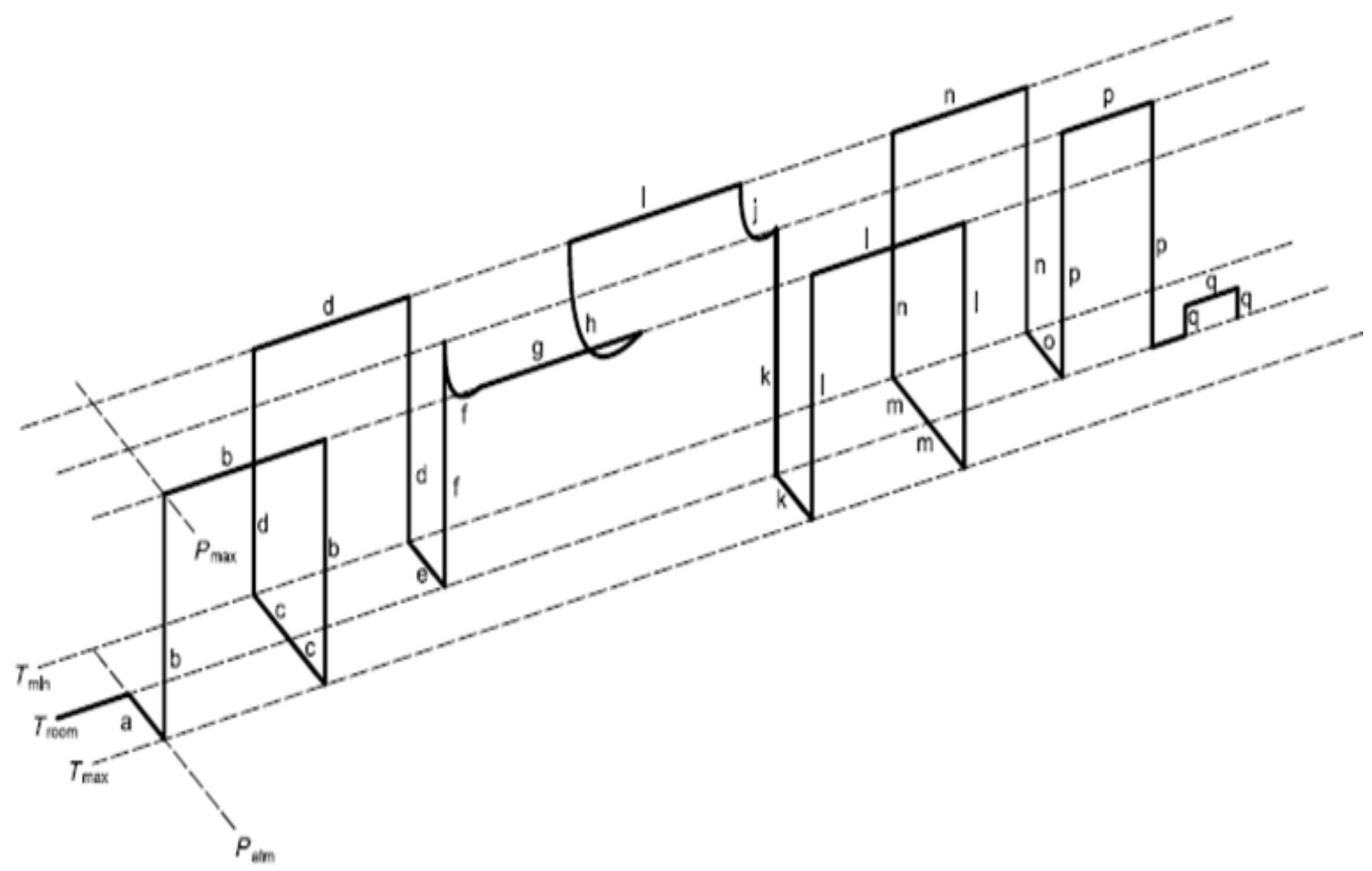

Figura 13 - Gráfico llustrativo de Pressão e Temperatura ao longo do Teste

Cada letra no gráfico da Figura 13 corresponde a uma etapa do procedimento de teste. Os 20 ciclos exigidos para uma qualificação PR-2 são 20 repetições da etapa b e 20 repetições da etapa d, isto é, 20 ciclos de abertura e fechamento à máxima e à mínima temperatura de projeto. 


\subsection{Análise do tempo de teste}

A cronoanálise é a base para controle das diversas etapas de um processo produtivo que fornece como parâmetro base o tempo padrão de certa atividade, possibilitando a geração de indicadores para melhoria contínua.

O tempo previsto para as 8 etapas da montagem do setup, conforme descrito na seção 3.3, é de 6 horas.

Pode-se calcular o tempo do teste descrito no procedimento da seção 3.3 pelo simples cálculo apresentado a seguir. Note que os tempos são os mínimos requeridos para execução de certa etapa e são calculados baseados em duração de ciclo de abertura e fechamento da válvula (4 minutos) bem como taxas de pressurização (1000 psi por minuto), de aquecimento e resfriamento (dados fornecidos pelos engenheiros responsáveis). Não são dados obtidos por cronoanálise e por isso é muito provável que o tempo total calculado seja menor que o necessário para executar as etapas em laboratório.

$$
\text { Tempo Total }=\text { Tempo de setup }+\sum_{1}^{N} t i,
$$

onde $N=17$ etapas e ti é o tempo da etapa $i$, por exemplo, $\mathrm{t}_{\mathrm{i}}=\mathrm{a}$ corresponde ao tempo da etapa $\mathbf{a}, \mathrm{t}_{\mathrm{i}=\mathrm{b}}$ corresponde à etapa $\mathbf{b}$ e assim por diante.

Pode-se considerar que as etapas $\mathbf{a}, \mathbf{f}$ e $\mathbf{k}$, que são os processos de aquecimento do conjunto a TMAX, partindo da temperatura ambiente, têm o mesmo tempo. Será desconsiderada a diferença entre tempos de aquecimento ou resfriamento com pressão e sem pressão de fluxo.

O parâmetro tempo de aquecimento varia muito de teste para teste, pois depende do calor fornecido pela resistência, do isolamento da câmara térmica e da massa do equipamento a ser testado. Não é conveniente calcular a transferência de calor entre o corpo da válvula, o atuador, as resistências, a placa bipartida de separação dual zone interna, os tubings de alimentação, os fluidos de pressurização e controle e o ambiente externo.

A troca de calor deste processo ocorre sob as três formas possíveis, convecção, condução e radiação. Por isso, será utilizada a experiência advinda de resultados de testes anteriores, que indicam que considerar 24 horas para aquecimento da 
válvula de 5" deste projeto é uma boa estimativa, visto que foi observado anteriormente que as válvulas de 5" levaram entre 20 a 36 horas para atingirem a temperatura máxima, ou seja,

$$
t \boldsymbol{a}=t \boldsymbol{f}=t \boldsymbol{k}=24 \text { horas. }
$$

As próximas etapas a serem analisadas serão as b e d: 20 ciclos de aproximadamente 15 minutos cada (incremento de 1000 psi por minuto até a pressão de teste e então abertura e fechamento da válvula, que é um pouco mais de 4 minutos) e, após essas 20 repetições, mais 10 minutos para atingir a pressão de teste e mantê-la por uma hora e despressurizar novamente, logo

$$
t \boldsymbol{b}=t \boldsymbol{d}=(20 * 15)+10+60=370 \text { minutos }=6,20 \text { horas. }
$$

As etapas c, $\mathbf{h}$ e $\mathbf{m}$ representam o tempo de resfriamento do conjunto a $\mathrm{T}_{\mathrm{MIN}}$, partindo de TMAX. É a etapa mais longa do teste de temperatura, pois o resfriamento do corpo para temperatura ambiente leva em torno de 10 horas. No entando, a injeção direta de gás $\mathrm{N}_{2}$ a $-196{ }^{\circ} \mathrm{C}$ é muito eficiente e, partindo da temperatura ambiente, o corpo atinge $-18{ }^{\circ} \mathrm{C}$ após menos de 8 horas de injeção de gás $\mathrm{N}_{2}$ na câmara de testes.

$$
t \boldsymbol{c}=t \boldsymbol{h}=t \boldsymbol{m}=10+8=18 \text { horas }
$$

As etapas de aquecimento para temperatura ambiente, partindo de $T_{M I N}$, são os processos e, j e o. É considerado o mesmo tempo de retorno à temperatura ambiente partindo de $T_{\text {MAX, }} 10$ horas:

$$
t e=t \boldsymbol{j}=t \boldsymbol{o}=10 \text { horas }
$$

As etapas g e i mantém a pressão e temperatura por 60 minutos:

$$
\operatorname{tg}=t \boldsymbol{i}=1 \text { hora }
$$

E as etapas I, $\mathbf{n}$ e $\mathbf{p}$ são calculadas por um ciclo completo (15 min) e os 60 minutos de hold pressure

$$
t \boldsymbol{l}=t \boldsymbol{n}=t \boldsymbol{p}=15+60=75 \text { minutos }=1,25 \text { horas }
$$

Por fim, a etapa q pode ser aproximada pelos 60 minutos de manter a vedação, já que a pressurização a montante é inferior a 1000 psi: 


$$
t \boldsymbol{q}=1 \text { hora }
$$

Com isso, calcula-se um tempo total de operação das etapas acima de:

$$
\begin{gathered}
\sum_{1}^{N} t i=3 * 24+2 * 6,20+3 * 18+3 * 10+2 * 1+3 * 1,25+1=175 \text { horas } \\
\text { Tempo Total }=6+175=181 \text { horas }
\end{gathered}
$$

Considerando que um dia de trabalho tem 8,8 horas, mas que em apenas $85 \%$ desse tempo um técnico está executando o teste, as etapas descritas poderiam ser concluídas em aproximadamente:

1 turno de 8,8 horas por dia:

$$
\begin{gathered}
X=8,8 * 0,85=7,48 \text { horas } \\
Y=181 / 7,48=25 \text { dias }
\end{gathered}
$$

2 turnos de 8,8 horas por dia:

$$
\begin{gathered}
X=2 * 8,8 * 0,85=15 \text { horas } \\
Y=181 / 15 \cong 12 \text { dias }
\end{gathered}
$$

3 turnos de 8,8 horas por dia:

$$
\begin{gathered}
X=3 * 8,8 * 0,85=22,44 \text { horas } \\
Y=181 / 22,44 \cong 8 \text { dias }
\end{gathered}
$$

Todos os valores acima consideram apenas um técnico trabalhando no teste. 


\section{Projeto da Câmara Térmica de Testes}

A câmara, além de atender aos requisitos do teste de temperatura sob norma API $6 \mathrm{~A}$, deve ser uma estrutura que permita um setup rápido e deve ter um isolamento térmico eficiente, que diminua as perdas térmicas durante o teste e otimize os tempos para atingir as temperaturas alvo.

Conforme visto na seção anterior, a temperatura máxima e mínima da câmara serão aproximadamente $250^{\circ} \mathrm{C}$ e $90^{\circ} \mathrm{C}$, respectivamente.

Todos os recursos necessários para este projeto foram fornecidos pelo Laboratório de Engenharia do Centro de Pesquisa e Tecnologia da TechnipFMC, onde a câmara será testada e utilizada para testes de qualificação de válvulas gaveta submarinas atuadas.

\subsection{Requisitos e especificações do projeto}

O objetivo principal da câmara de testes é isolar termicamente o equipamento, de forma a estabilizar a temperatura para execução dos testes. Por isso, é preciso que a câmara tenha seu volume interno otimizado, de forma que o equipamento troque menos calor possível com o ar interno que, por sua vez, troca calor com o ambiente externo. A câmara deve ter, também, uma separação isolante entre o corpo e o atuador, possibilitando o controle simultâneo das temperaturas das zonas.

Além das dimensões otimizadas, é preciso que a câmara possua uma estrutura que suporte um equipamento de 3 toneladas e ao mesmo tempo seja fácil de movimentar.

O aquecimento será feito com quatro resistências elétricas em contato direto com o equipamento, três em torno do corpo da válvula e uma em torno do atuador. Uma vez que as resistências sejam montadas na válvula e no atuador, é preciso assentar o conjunto em seu suporte de teste e conectar os tubings de pressurização no corpo e no atuador e os bicos injetores de gás $\mathrm{N}_{2}$ nas zonas 1 e 2.

Conforme apresentado na seção 3.3, sabe-se a parte mais crítica do teste de temperatura é o retorno à temperatura ambiente, pois são estas as etapas mais demoradas. Por isso, projetou-se forçar este retorno por meio de convecção 
forçada, conectando um ventilador centrífugo a um duto sanfonado que, por sua vez, estará conectado a um bocal com uma válvula borboleta simples, para que possa fechar a passagem quando o ventilador estiver desligado, em uma etapa de aquecimento, por exemplo. Os bocais com válvulas borboletas de saída de ar ficarão na parte superior de cada zona para "perder" calor para o ambiente mais rapidamente, já que o ar quente, aquecido pelas resistências, sobe. As válvulas borboletas dos bocais de entrada abrem para dentro devido à vazão do ventilador e as de saída abrem para fora devido à pressão positiva que cria-se dentro da câmara devido a essa injeção de ar externo.

Dimensionamento da câmara de testes:

- Estrutura: chapas de aço A-36 36 ksi (248 MPa) ASTM soldadas e reforçadas com cantoneiras;

- Isolamento térmico interno: Novolastic ${ }^{\mathrm{TM}}$;

- Movimentação: olhais e encaixe para garfo de empilhadeira;

- Posição da válvula para teste: Vertical;

- Aquecimento: resistências elétricas;

- Resfriamento: injeção direta de gás nitrogênio $\left(\mathrm{N}_{2}\right)$; e

- Convecção forçada: 4 bocais para troca de calor com o ambiente.

As dimensões da caixa dependem da válvula do projeto, então é preciso utilizar as dimensões do corpo, do atuador e dos tubings de pressurização para modelá-la.

O dimensionamento dos olhais foi feito utilizando uma memória de cálculo da TechnipFMC para o dimensiomento de olhais em situação crítica de trabalho. Os principais dados de entrada foram:

- Içamento com 4 pernas;

- 3,5 t como carga máxima de içamento;

- Olhal com furo de 1/2"' (12,7 mm); e

- Tensão de Escoamento aço A-36: 36 ksi (248 MPa).

Isso resultou em um fator de segurança de 1,34, que é seguro e aceitável para este projeto. 
A Figura 14 apresenta os principais parâmetros para o dimensionamento de um olhal para içamento:
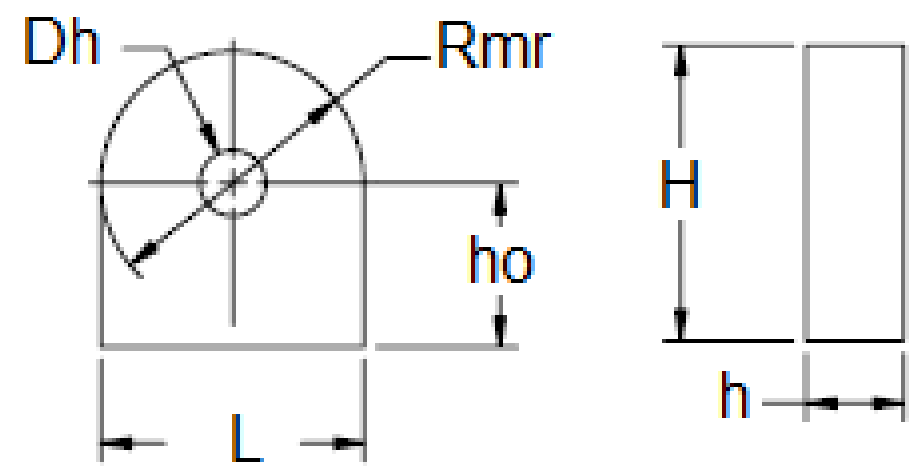

Figura 14 - Desenho 2D: Parâmetros principais de um olhal de içamento

Dimensões:

- Largura: $L=50,8 \mathrm{~mm}$;

- Distância da base até o centro do furo: ho $=31,8 \mathrm{~mm}$;

- Diâmetro do furo: $\mathrm{DH}=12,7 \mathrm{~mm}$;

- Raio mínimo: $\mathrm{Rmr}=50,8 \mathrm{~mm}$;

- Altura: $\mathrm{H}=57,2 \mathrm{~mm}$; e

- Espessura do Olhal: $\mathrm{h}=19 \mathrm{~mm}$.

O material para isolamento térmico escolhido foi o Novolastic $^{\mathrm{TM}}$, que é um isolamento sofisticado para tubulações submarinas em campos de E\&P de petróleo. O isolamento de dutos de produção é necessário pois, quando o óleo sai quente do fundo do poço e chega à tubulação, que está com temperatura muito inferior, inicia-se um fenômeno chamado de deposição de parafina, no qual partes sólidas do óleo começam a solidificar e a acumular nas paredes dos dutos causando, muitas vezes, entupimento das tubulações. Por ser um material patenteado pela FMC Technologies (atual TechnipFMC), este material é um recurso disponível para o projeto da câmara.

A espessura do isolamento será de 1" $(25,4 \mathrm{~mm})$ nas paredes internas e 2" para a placa de separação dual zone. As dimensões de largura e comprimento não serão detalhadas, pois o material será aplicado diretamente na parte interna da caixa. No entanto, é definido que a placa será bipartida, para que seja possível a separação do conjunto válvula e atuador montados, conectados através do bonnet. 
Um ponto negativo de utilizar este eficiente isolamento térmico é que sua densidade é um pouco maior do que a da água $\left(1000 \mathrm{~kg} / \mathrm{m}^{3}\right)$, e por isso, a câmara ficará mais pesada. $\mathrm{O}$ Novolastic ${ }^{\mathrm{TM}}$ apresenta as seguintes características:

- Densidade: $1073 \mathrm{~kg} / \mathrm{m}^{3}$;

- Calor específico: $2,18 \mathrm{~kJ} / \mathrm{kg} * \mathrm{~K}$;

- Difusividade térmica: $7,743 * 10^{-8} \mathrm{~m}^{2} / \mathrm{s}$; e

- Condutividade térmica: $0,208 \mathrm{~W} /(\mathrm{m} * \mathrm{~K})$;

A modelagem da câmara foi feita no software NX, conforme ilustrado nas Figuras 15 a 18. A Tabela 6 apresenta a relação de material necessário para construção da câmara de testes.

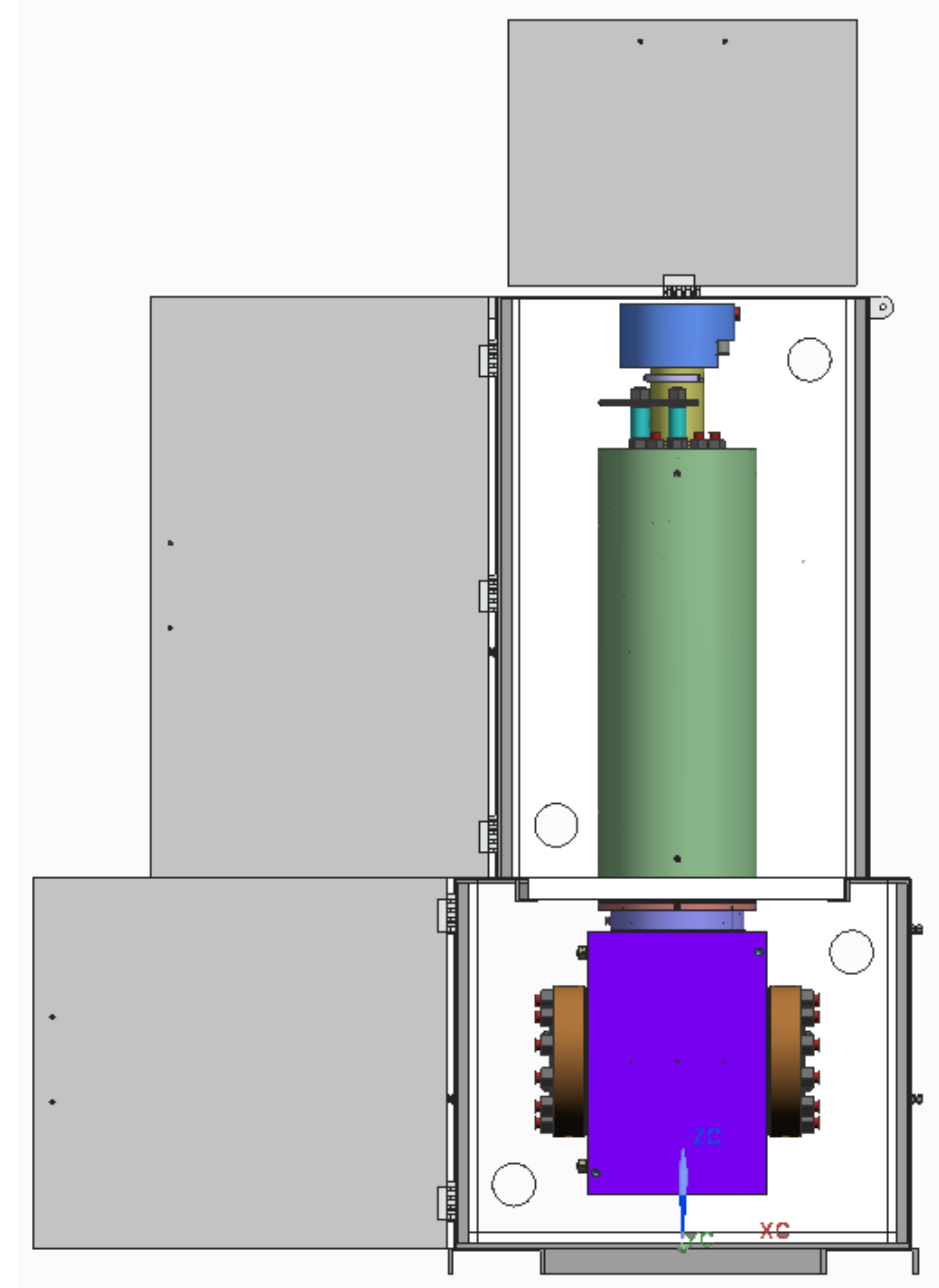

Figura 15 - Desenho 3D da câmara de teste com a válvula posicionada. 


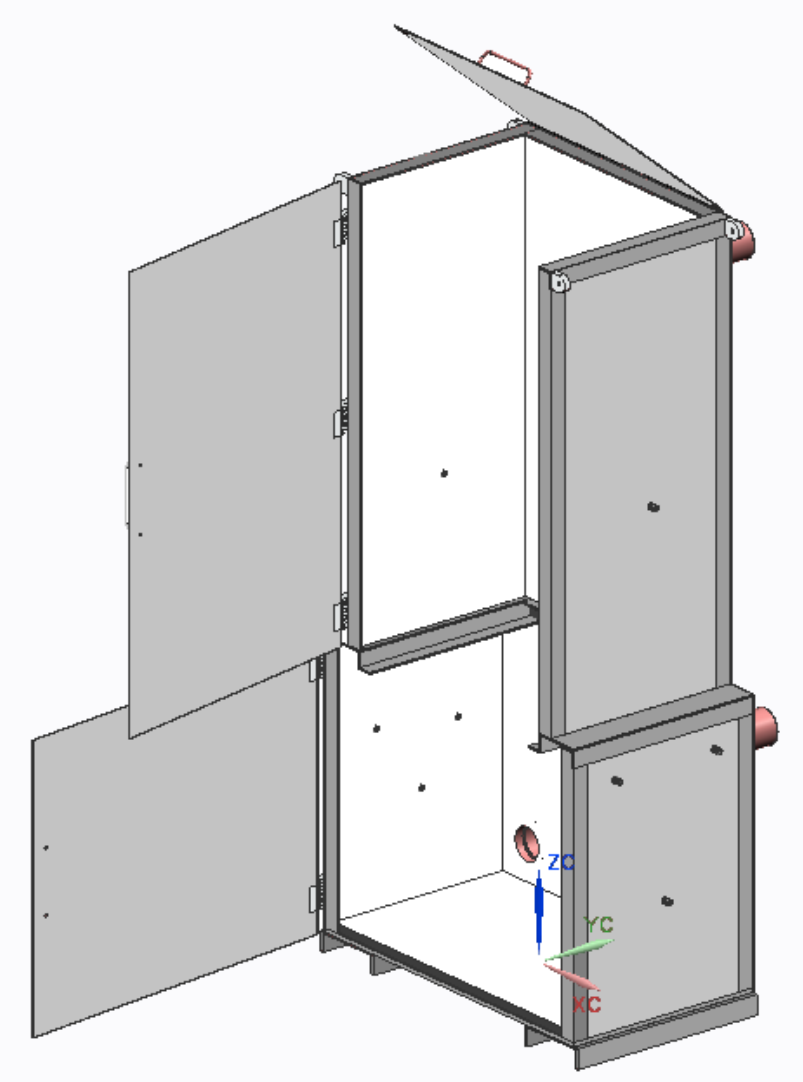

Figura 16 - Desenho 3D da estrutura de aço da câmara de testes com isolamento interno.
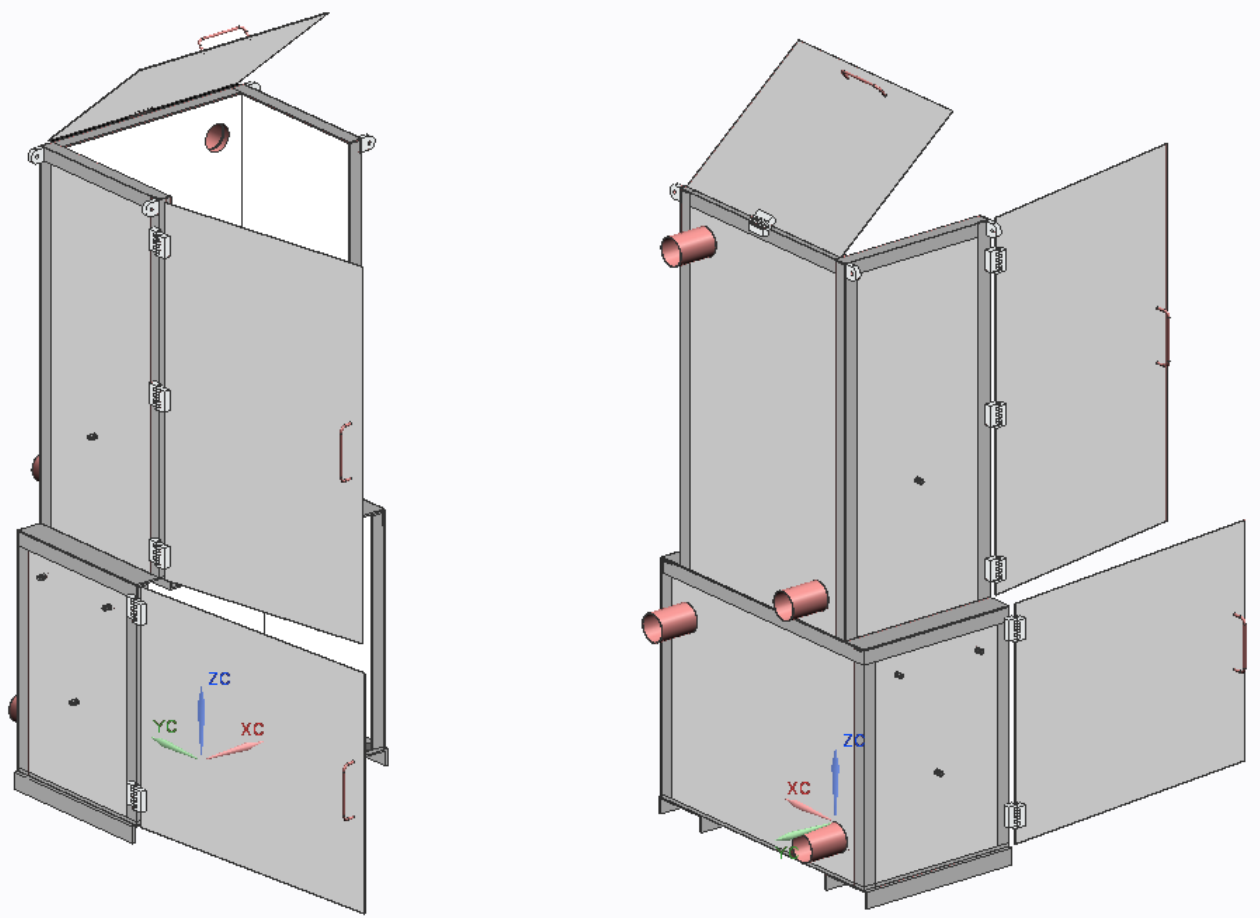

Figura 17 - Desenho 3D da estrutura de aço com isolamento interno. 

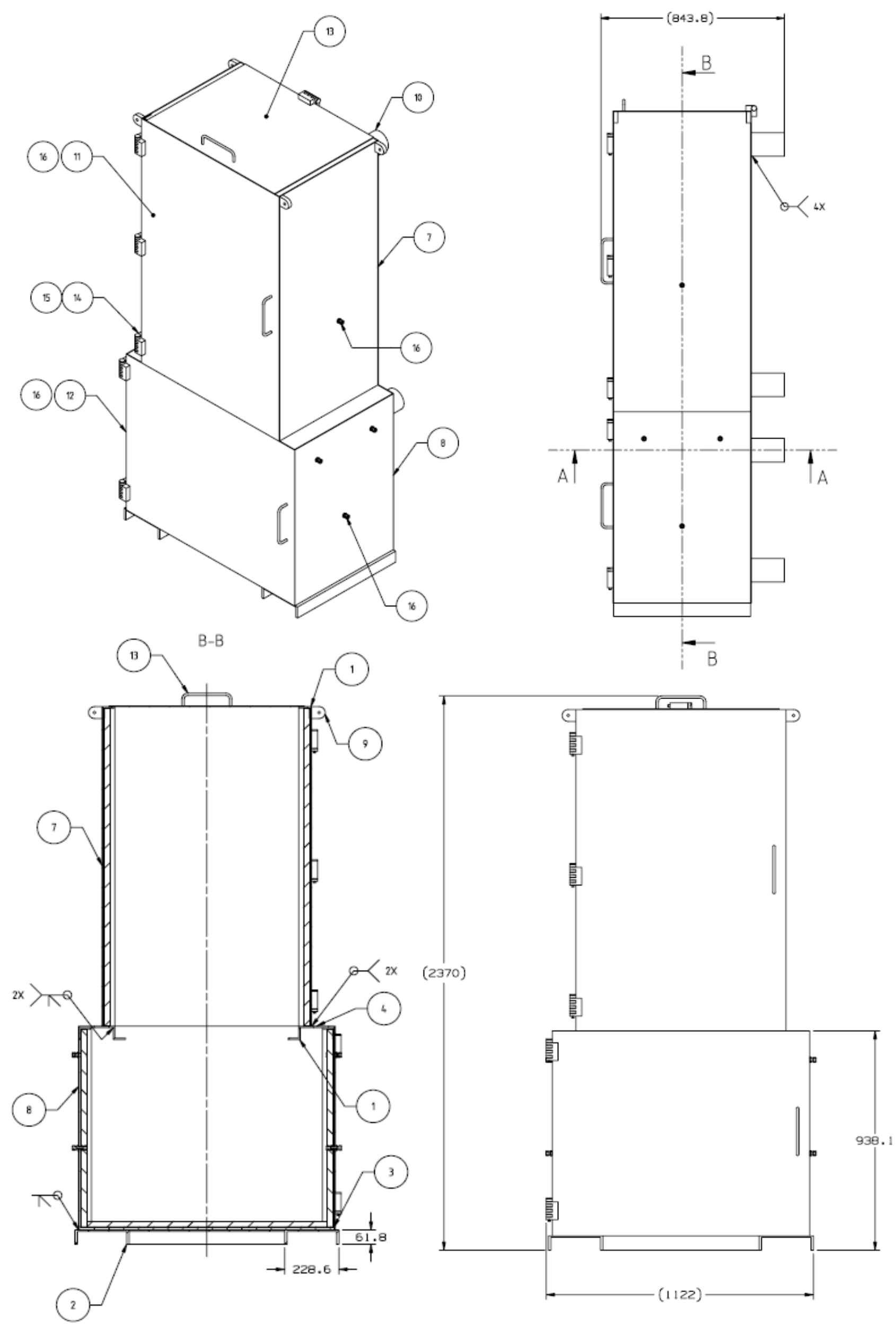

Figura 18 - Desenho detalhado da estrutura da câmara de testes. 
Tabela 5 - Itens para fabricação da câmara de testes

\begin{tabular}{|c|l|c|}
\hline ITEM & \multicolumn{1}{|c|}{ DESCRIÇÃO } & QNT \\
\hline 1 & Cantoneira $(2 " \times 2 " \times 1 / 4 ")$ & 16 \\
\hline 2 & VIGA C $(10 " \times 12.77 \mathrm{~kg} / \mathrm{m})$ & 3 \\
\hline 3 & CHAPA DE AÇO A-36 $-127 \mathrm{~mm}$ & 1 \\
\hline 4 & CHAPA DE AÇO A-36 $-64 \mathrm{~mm}$ & 2 \\
\hline $5,6,7,8$ & CHAPA DE AÇO A-36 $-32 \mathrm{~mm}$ & 6 \\
\hline 9 & OLHAL 1/2" & 4 \\
\hline 10 & BOCAL VENTOINHA & 4 \\
\hline 11 & TAMPA SUPERIOR & 1 \\
\hline 12 & TAMPA ZONA 1 & 1 \\
\hline 13 & TAMPA ZONA 2 & 6 \\
\hline 14 & DOBRADIÇA & 6 \\
\hline 15 & PINOS & 8 \\
\hline 16 & BICO INJETOR DE GÁS & 10 \\
\hline 17 & BARRIS DE NOVOLASTIC & \\
\hline
\end{tabular}

\subsection{Prototipagem}

Prototipar a solução escolhida para o projeto é parte importante de seu desenvolvimento, pois nesta fase é possível reduzir as principais incertezas do projeto e antecipar eventuais gargalos ou problemas. Além disso, é na etapa de construção e teste do protótipo em que as ideias saem do papel e é possível identificar possíveis otimizações antes do projeto ser liberado para fabricação. Isso representa um grande ganho de produtividade e redução de custos.

A prototipagem é largamente utilizada no desenvolvimento de diversos tipos de produtos, desde os mais simples projetos aos mais complexos como os da indústria automotiva, cosmética, civil, aeronáutica, software, etc. Os requisitos apresentados na seção anterior foram analisados e foi modelado um protótipo simples para testar a solução da câmara de teste.

Todo protótipo visa esclarecer possíveis dúvidas do projeto e as principais incertezas deste são:

I. A espessura da placa bipartida de separação de Novolastic TM (2") é suficiente para criar duas zonas com temperaturas independentes? 
II. O corpo da válvula, por condução, aquece o atuador acima de sua temperatura máxima? Resfria abaixo da mínima?

III. É possível a estabilização (variação menor que $0,5{ }^{\circ} \mathrm{C} / \mathrm{min}$ ) da temperatura utilizando o Novolastic como isolante térmico?

Deve-se notar que estudar o tempo de aquecimento e resfriamento do conjunto da válvula de 2" que será utilizada neste protótipo não é interessante, pois a diferença de massa entre válvulas de diferentes projetos já é grande, sendo ainda maior no caso de diferentes dimensões nominais, como neste caso 2" e 5". Isto ocorre porque as taxas de transferência de calor não variam linearmente com a massa, então uma rápida comparação de tempos de aquecimento ou resfriamento não resultaria em informações confiáveis.

\subsubsection{Desenvolvimento e Construção do protótipo}

Conforme apresentado acima, é preciso planejar a construção de um protótipo que elimine as dúvidas e diminua as incertezas e imprevistos do projeto final. O maior risco desse projeto é garantir a diferença de temperaturas entre as zonas 1 e 2 (dúvida I). É preciso manter a temperatura da zona 2 a máximo $75^{\circ} \mathrm{C}$ enquanto a zona 1 estará a no máximo $250^{\circ} \mathrm{C}$ e, também, manter a zona 2 a $0{ }^{\circ} \mathrm{C}$ ou mais enquanto a zona 1 estiver a $-40^{\circ} \mathrm{C}$.

Por isso, o requisito número um do protótipo será utilizar uma placa bipartida de isolamento de 2" de Novolastic ${ }^{\mathrm{TM}}$ separando as duas zonas. Além disso, será preciso incluir dois furos na tampa da zona 1 para injeção de gás $\mathrm{N}_{2}$ (utilizado para resfriamento). Apesar do projeto da câmara prever furos para bicos injetores de gás $\mathrm{N}_{2}$ em cada zona, no teste do protótipo será analisado apenas se a temperatura da zona 2 fica abaixo da temperatura mínima alvo do atuador (duvida II). Espera-se que a temperatura da zona 2 fique acima e que seja necessário injetar gás $\mathrm{N}_{2}$ também na zona 2 para que o atuador chegue a $0{ }^{\circ} \mathrm{C}$. Se a temperatura da zona 2 for inferior a $0{ }^{\circ} \mathrm{C}$ quando o corpo da válvula atingir $-18^{\circ} \mathrm{C}$, então a placa de 2" que separa a zona 1 da zona 2 não é suficiente e será necessário aumentar a espessura da separação. Não será preciso fazer os furos para instrumentação de pressão, pois não há dúvidas quanto à pressurização do equipamento neste teste do protótipo. 
Para a montagem do protótipo, foram amarradas fitas de poliamida prendendo as chapas de MDF nas placas de 1" de isolamento térmico Novolastic ${ }^{\mathrm{TM}}$ e as chapas foram montadas de forma a modelar uma caixa. O setup da válvula foi montado amarrando as resistências em volta do corpo e do atuador. Dois suportes foram colocados dentro da caixa e em seguida foi assentada uma válvula de 2" com seu atuador. Instalaram-se os RTDs (PT-100) e integrou-se todo o sistema de temperatura, os RTDs, o controle das resistências e da válvula pneumática de gás nitrogênio, ao software que faz o controle e monitoramento automatizado do teste. A tampa desta câmara-protótipo foi feita de uma chapa de lã de rocha $(500 \mathrm{~mm} X$ $1700 \mathrm{~mm}$ ) para baratear o custo, permitindo economizar $22 \mathrm{~L}$ de Novolastic ${ }^{\mathrm{TM}}$. A Tabela 7 presenta as dimensões da caixa.

Tabela 6 - Dimensões da caixa-protótipo

\begin{tabular}{|l|c|}
\hline \multicolumn{2}{|c|}{ Dimensões da caixa $(\mathrm{mm})$} \\
\hline Altura & 600 \\
\hline Largura & 500 \\
\hline Comprimento & 1700 \\
\hline
\end{tabular}

A Figura 20 apresenta a câmara-protótipo com os suportes assentados, aguardando o içamento da válvula de 2".

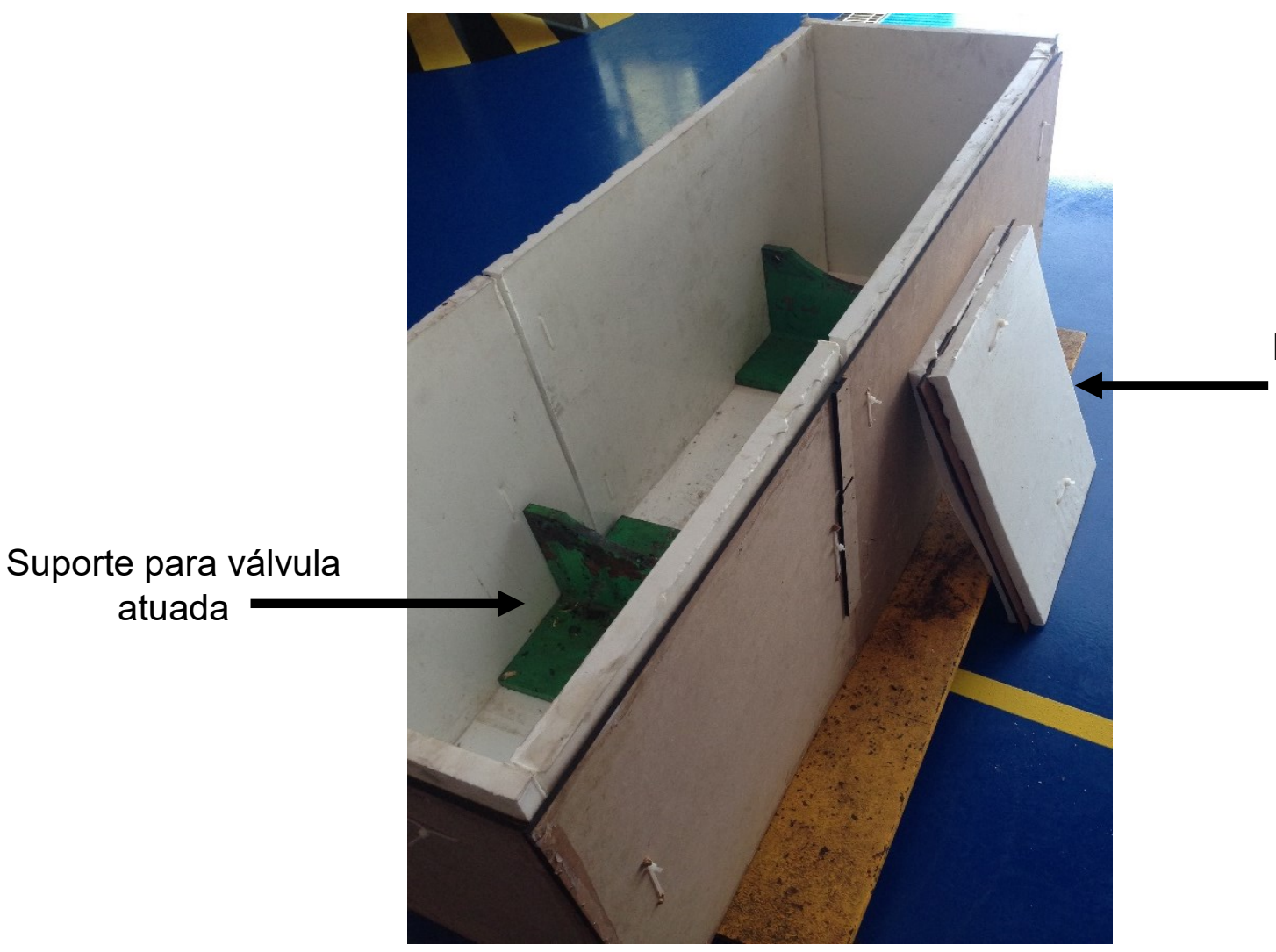

Placa de separação de 2" de

Figura 19 - Câmara-Protótipo 


\subsubsection{Teste do Protótipo}

Tanto a aquisição de dados de temperatura do teste quanto o controle das resistências e injeção de gás nitrogênio foi controlado e monitorado por um programa automatizado. Quatro RTDs foram instalados na zona 1 para fazer o controle e monitoramento e apenas um foi instalado no atuador para monitoramento. O teste consistiu no controle da temperatura do corpo (VG), segundo o procedimento abaixo:

1) Aquecer o corpo até $180^{\circ} \mathrm{C}$;

2) Manter a temperatura a $180^{\circ} \mathrm{C}$ por uma hora;

3) Aguardar o corpo resfriar naturalmente até aproximadamente $50^{\circ} \mathrm{C}$;

4) Resfriar até $-29^{\circ} \mathrm{C}$ com injeção de gás $\mathrm{N}_{2}$;

5) Manter a temperatura a $-29^{\circ} \mathrm{C}$ por uma hora; e

6) Monitorar a volta à $T_{A M B}$.

\subsubsection{Resultados}

A Figura 20 apresenta o gráfico do teste completo.

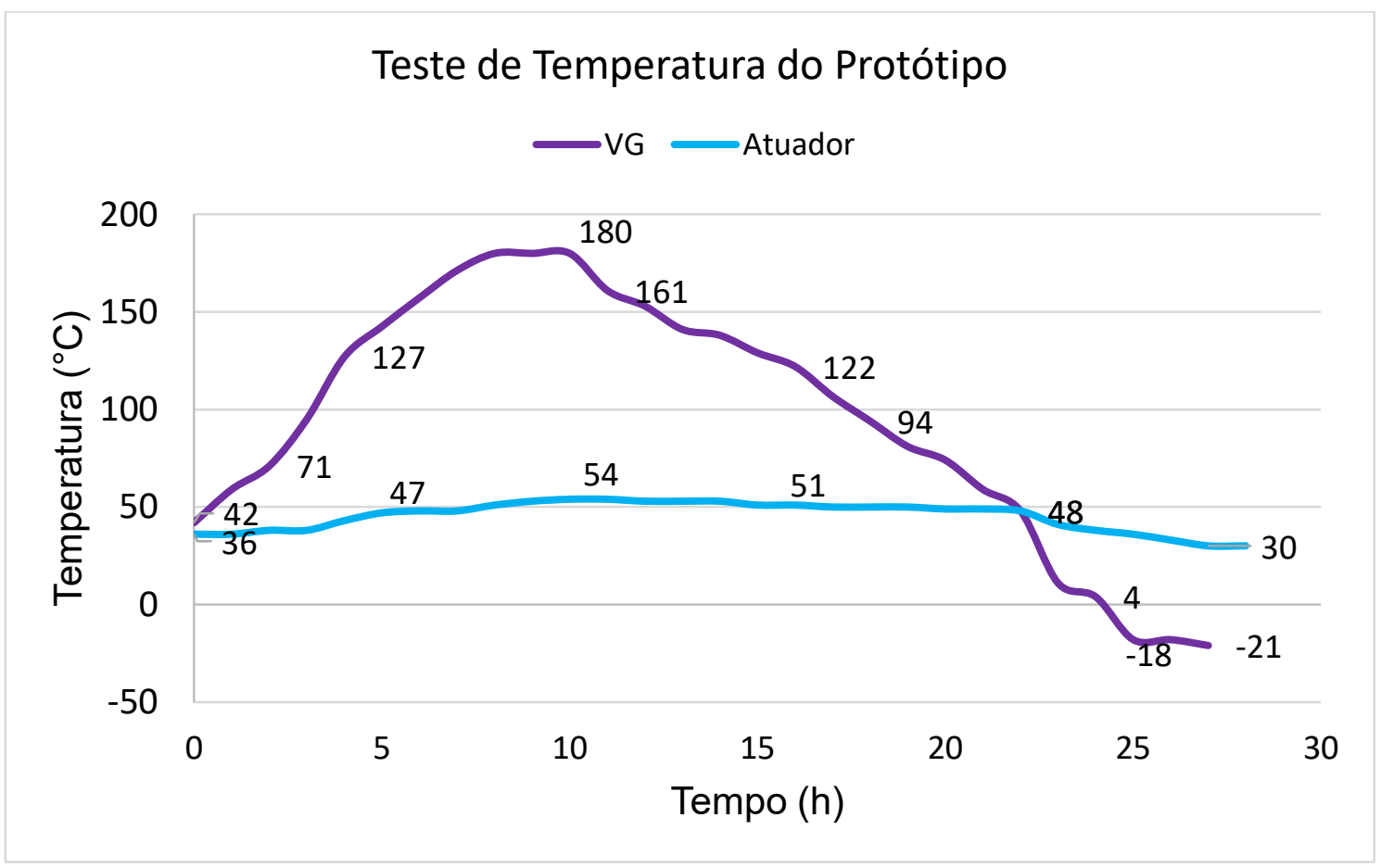

Figura 20 - Gráfico completo do teste de temperatra do protótipo 
Na Figura 20, rapidamente pode-se observar que a placa bipartida de 2" de Novolastic $^{\mathrm{TM}}$ foi suficiente para manter a temperatura da zona 2 abaixo de sua temperatura máxima e acima de sua temperatura mínima de teste. Não foi possível registrar os resultados do retorno à temperatura ambiente, partindo da temperatura mínima do corpo da válvula, somente partindo da máxima como pode ser visualizado na mesma Figura 20.

É difícil observar em quanto tempo o corpo da válvula atingiu $180{ }^{\circ} \mathrm{C}$ e se a temperatura ficou estável por uma hora, ou seja, com uma variação menor que $\left(0,5^{\circ} \mathrm{C} / \mathrm{min}\right)$. Por isso, a Figura 21 apresenta o gráfico da etapa de aquecimento e estabilização da temperatura do corpo da válvula.

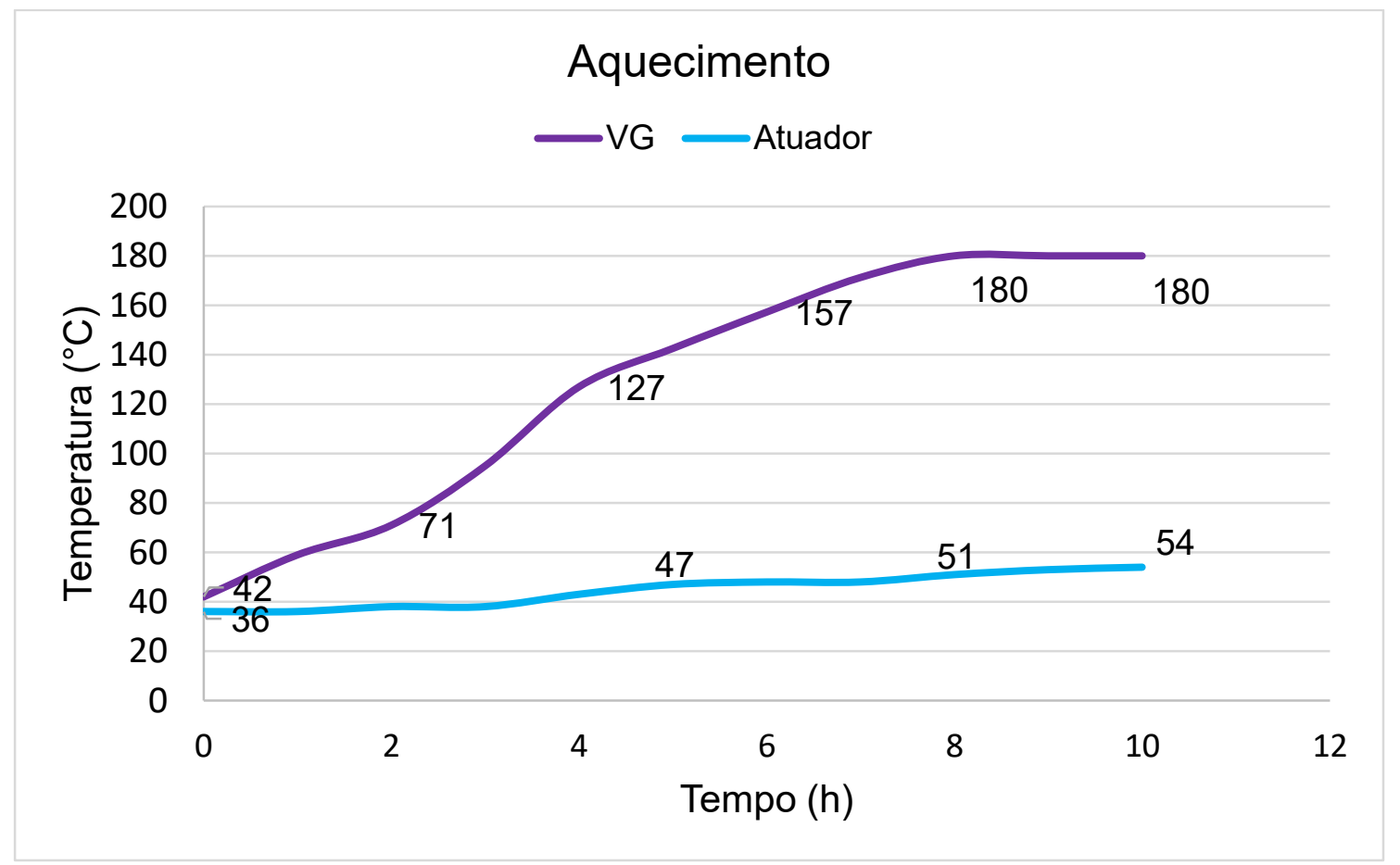

Figura 21 - Gráfico do Aquecimento do corpo e do atuador no teste do protótipo Com o gráfico da Figura 21 é possível observar que foram necessárias 8 horas para que o corpo atingisse $180^{\circ} \mathrm{C}$ e o atuador não chegou a atingir $55^{\circ} \mathrm{C}$, ou seja, ficou bem abaixo de sua temperatura máxima, como desejado.

A estabilização da temperatura foi alcançada alguns minutos depois do corpo ter atingido $180^{\circ} \mathrm{C}$ pela primeira vez. 
A Figura 22 apresenta a etapa de retorno à temperatura ambiente.

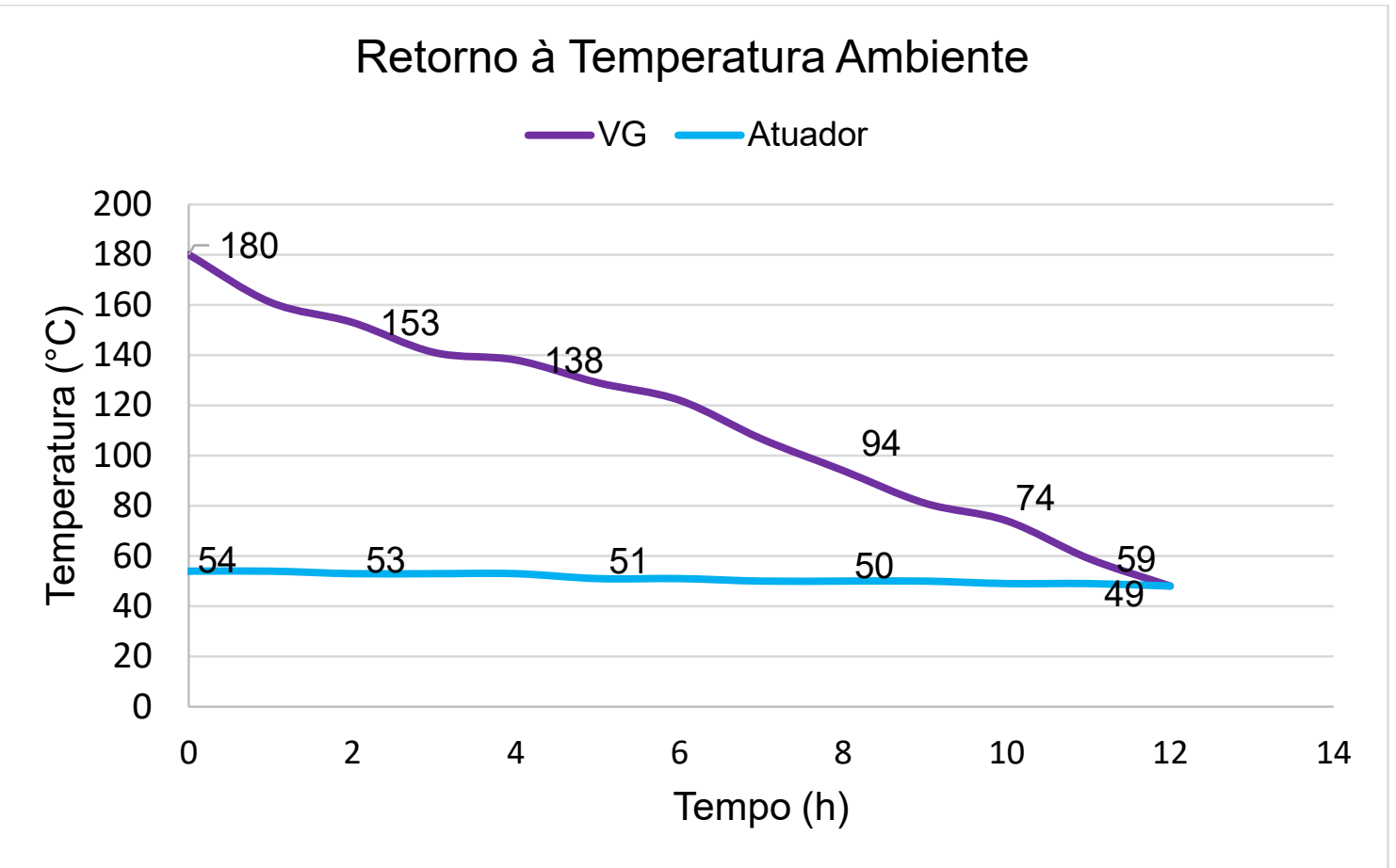

Figura 22 - Gráfico do retorno à $\mathrm{T}_{\mathrm{AMB}}$ do corpo e do atuador no teste do protótipo

Esta etapa demorou mais do que o previsto de 10 horas conforme analisado na seção 3.3. No entanto, era esperado que fosse uma etapa longa, por isso os bocais de entrada e saída de ar foram projetados para forçar uma convecção com o ar. Isto pode, também, ser analisado como um resultado negativo ao uso do Novolastic $^{\mathrm{TM}}$ pois este é um isolante muito eficiente. Uma possível solução para este problema será apresentada na próxima seção.

A etapa de resfriamento teve um ótimo tempo de execução, 3 horas, como apresentado na Figura 23. A temperatura só estabilizou uma hora após atingir -21 ${ }^{\circ} \mathrm{C}$, na $5^{\mathrm{a}}$ hora de teste. 


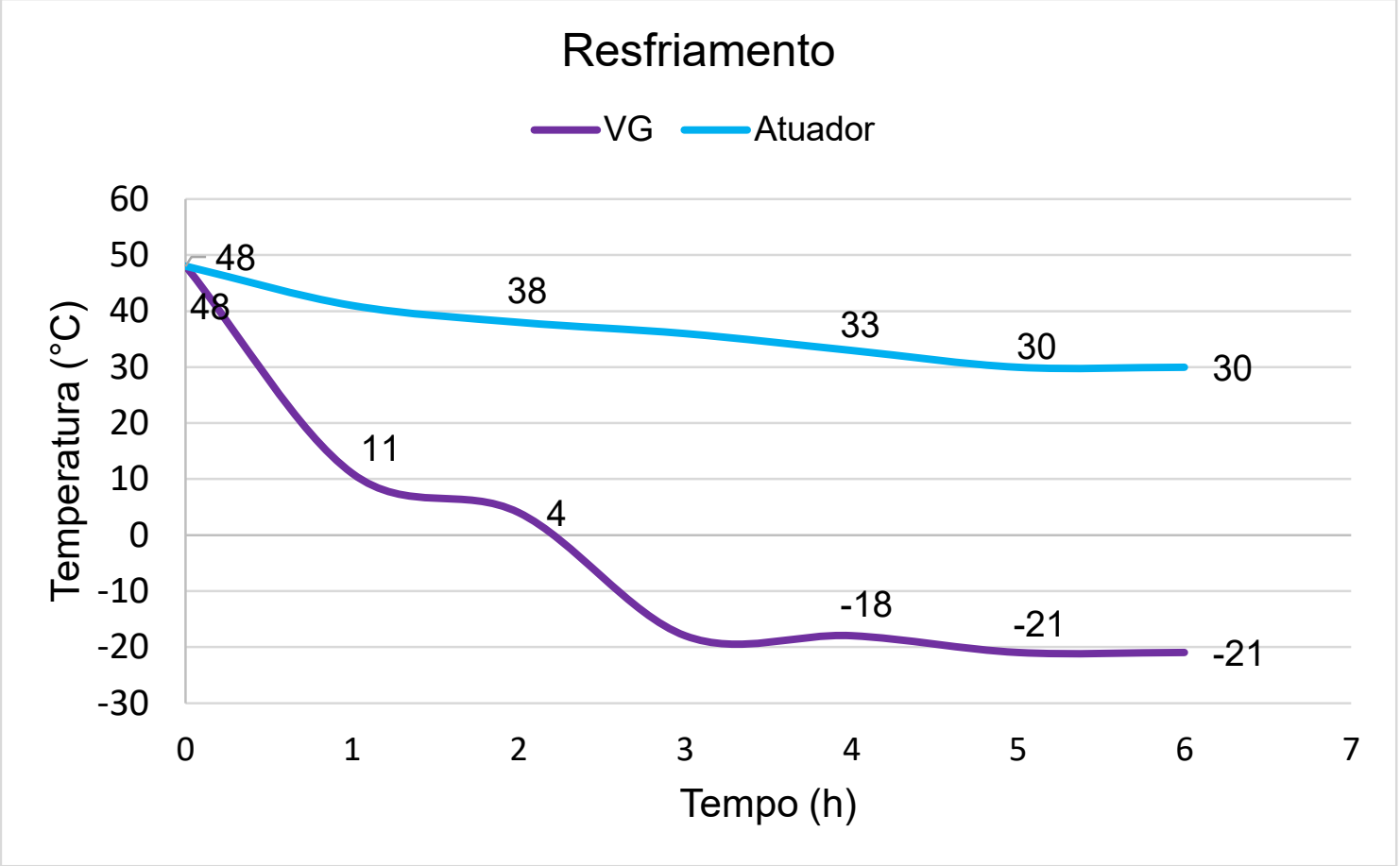

Figura 23 - Gráfico do Resfriamento do corpo e do atuador no teste do protótipo

Assim, pode-se tecer as seguintes conclusões referentes aos questionamentos da seção 4.2:

I. A espessura da placa bipartida de separação de Novolastic TM (2") é suficiente para criar as duas zonas com temperaturas independentes pois, quando o corpo atingiu $180^{\circ} \mathrm{C}$, o atuador ainda estava a $54^{\circ} \mathrm{C}$, e no resfriamento, quando o corpo atingiu $-21^{\circ} \mathrm{C}$, o atuador estava em $30^{\circ} \mathrm{C}$. Isto significa que realmente é necessário montar resistências e o dispositivo de resfriamento na zona do atuador para controlar sua temperatura também.

II. Foi percebido que o principal mecanismo de troca de calor entre a zona 1 e a zona 2 é de fato a condução. No entanto, essa transferência de calor da zona 1 para a zona 2 não foi suficiente para superaquecer o atuador, isto é, aquecêlo acima de sua temperatura máxima. E nem para resfriá-lo demais, pois sua temperatura mínima foi de $30{ }^{\circ} \mathrm{C}$. A temperatura do atuador não sofreu muito com o resfriamento da válvula, pois não houve tempo suficiente para o calor ser transmitido por condução de forma a resfriá-lo. 
III. A câmara de testes com isolamento interno de Novolastic se mostrou capaz de estabilizar a temperatura (variação menor que $0,5^{\circ} \mathrm{C} / \mathrm{min}$ ), no entanto, o retorno à temperatura ambiente foi muito demorado e precisa ser melhorado.

\subsection{Design Review - Revisão do Projeto}

Após a análise dos resultados do teste com o protótipo, foi verificado que o retorno à temperatura ambiente foi muito demorado. A ideia dos bocais na estrutura da câmara para entrada de ar inflado e saída de ar para retorno a TAMB não pôde ser testada nesse protótipo, mas concluiu-se como sendo necessária.

Para simplificar o projeto, uma possível solução é conectar o dispositivo de resfriamento a uma alimentação de ar comprimido para forçar a troca de calor com o meio externo quando o conjunto tiver que voltar à TAMB. Sendo assim, os bocais para entrada de ar, bem como o ventilador centrífugo e os dutos sanfonados, não serão mais necessários.

\subsection{Fabricação e Montagem da Câmara de Testes}

Após a análise dos dados do teste com o protótipo iniciou-se a etapa de cotações. O desenho da caixa metálica foi enviado a dois fornecedores que cotaram a caixa com prazo de entrega de 45 dias no valor de aproximadamente $R \$ 10.000,00$. Como o prazo de entrega da câmara de testes ao Laboratório era menor que 45 dias a partir da resposta à cotação, a câmara de estrutura metálica foi adicionada à lista de melhorias desejadas para o laboratório e em breve será implementada. Como o projeto deve atender a todos os requisitos, principalmente ao prazo de entrega, foi decidido utilizar chapas de madeira ao invés de aço A-36.

Após essa decisão, o desenho foi enviado para cotação com um fornecedor de caixas de madeira que, apesar de entrega em três dias úteis, só fornece dimensões pré-fabricadas, o que não permite otimizar o volume interno da câmara. Sendo assim, será necessário mais tempo para que a válvula e o atuador atinjam suas temperaturas alvo, uma vez que a temperatura interna da câmara demorará mais tempo para estabilizar, resultando em ciclos de aquecimento e resfriamento mais demorados do que o previsto inicialmente pelo projeto. 
Outro ponto que teve que ser modificado devido à estrutura de madeira é a posição da válvula durante o teste. O conjunto foi posicionado na horizontal, pois a estrutura não dispõe de tampa superior que possibilite o assentamento do conjunto na vertical.

A Tabela 8 apresenta as dimensões externas da estrutura de madeira da câmara de testes e as Figuras 25 a 29 apresentam alguns itens que compõem a câmara de testes.

Tabela 7 - Dimensões externas da estrutura de madeira da câmara de testes

\begin{tabular}{|c|c|}
\hline \multicolumn{2}{|c|}{ Dimensões externas da câmara $(\mathrm{mm})$} \\
\hline Altura & 1300 \\
\hline Largura & 1000 \\
\hline Comprimento & 2750 \\
\hline
\end{tabular}

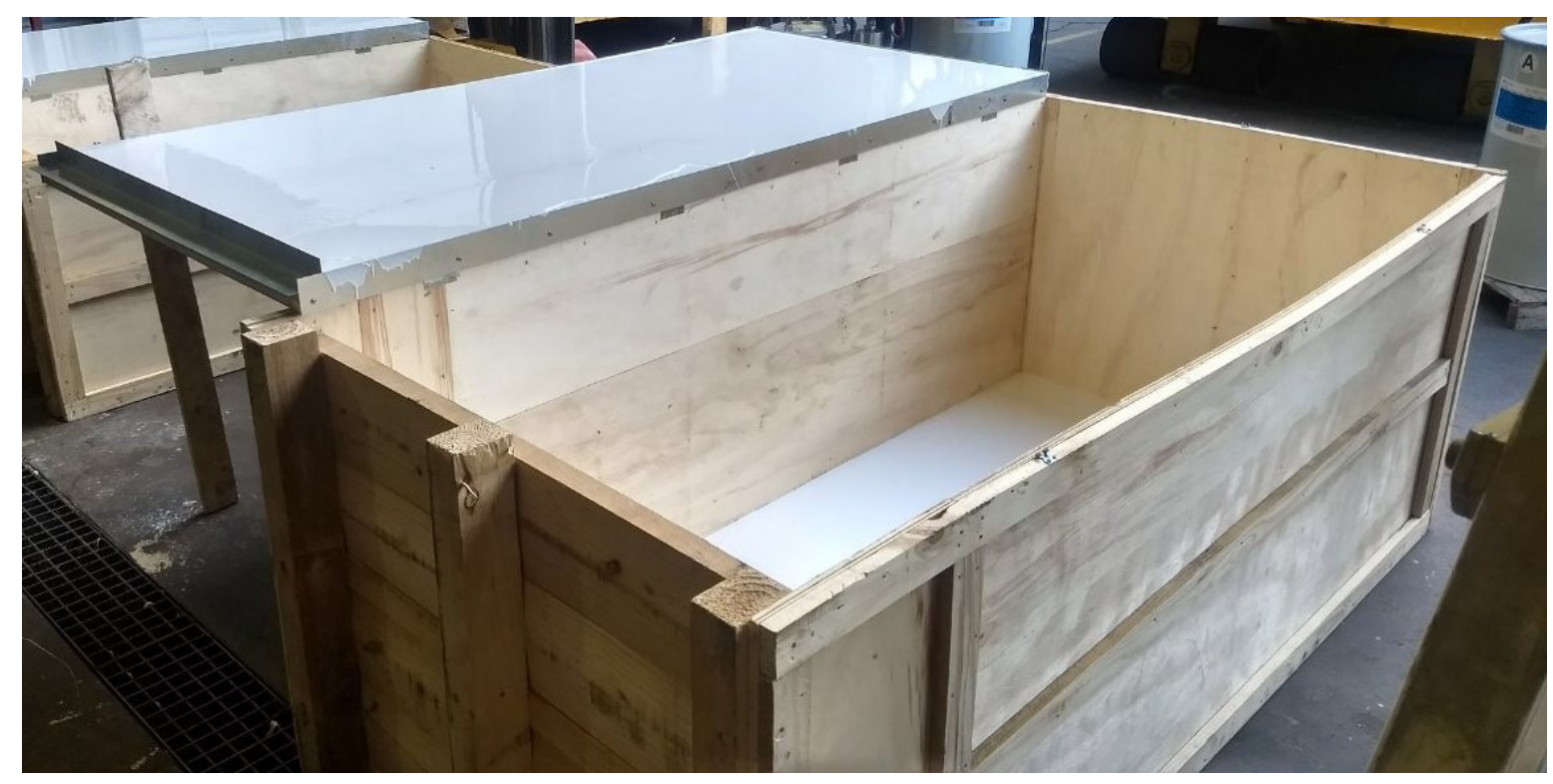

Figura 24 - Aplicação do isolamento térmico Novostic ${ }^{\mathrm{TM}}$ na parede interna 


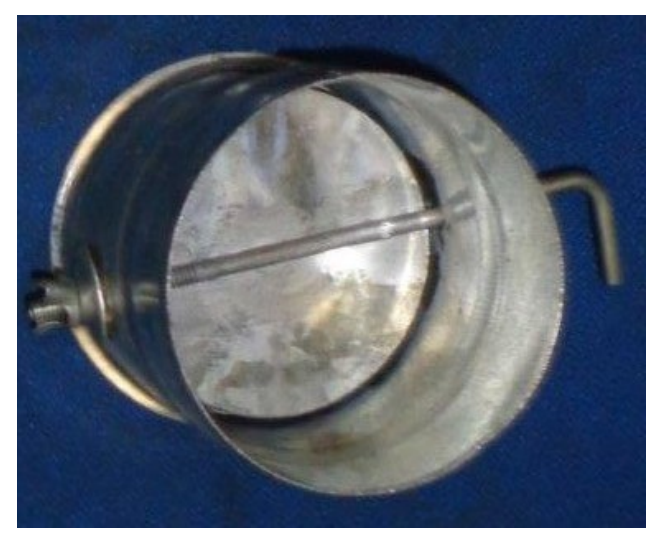

Figura 26 - Válvula borboleta para bocais de saída de ar

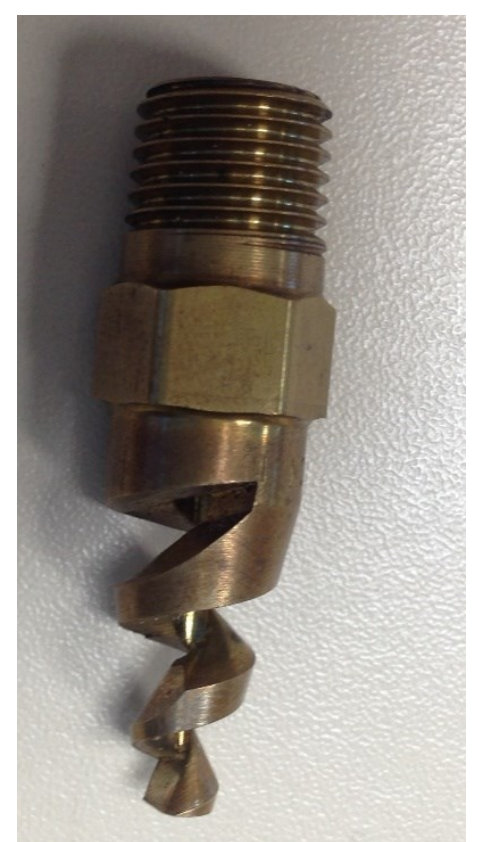

Figura 25 - Bico difusor de gás nitrogênio e ar

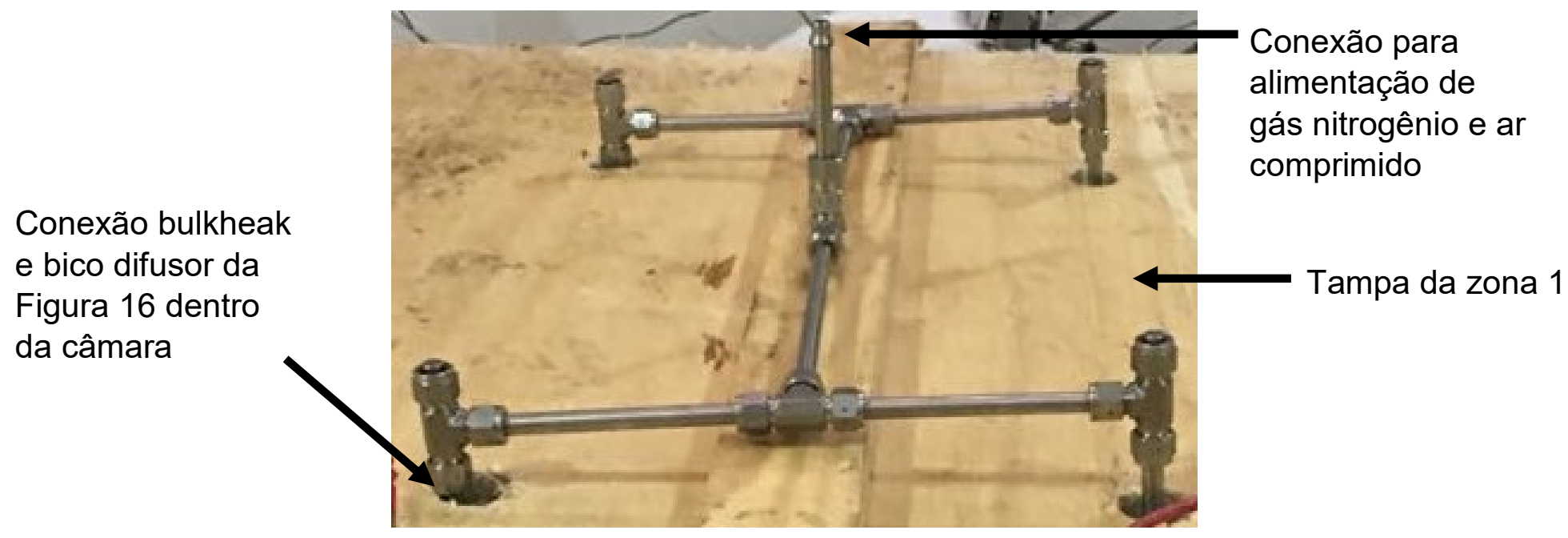

Figura 27 - Dispositivo de resfriamento/ volta para temperatura ambiente 
Os fios das resistências devem ser conectados fora da câmara de teste

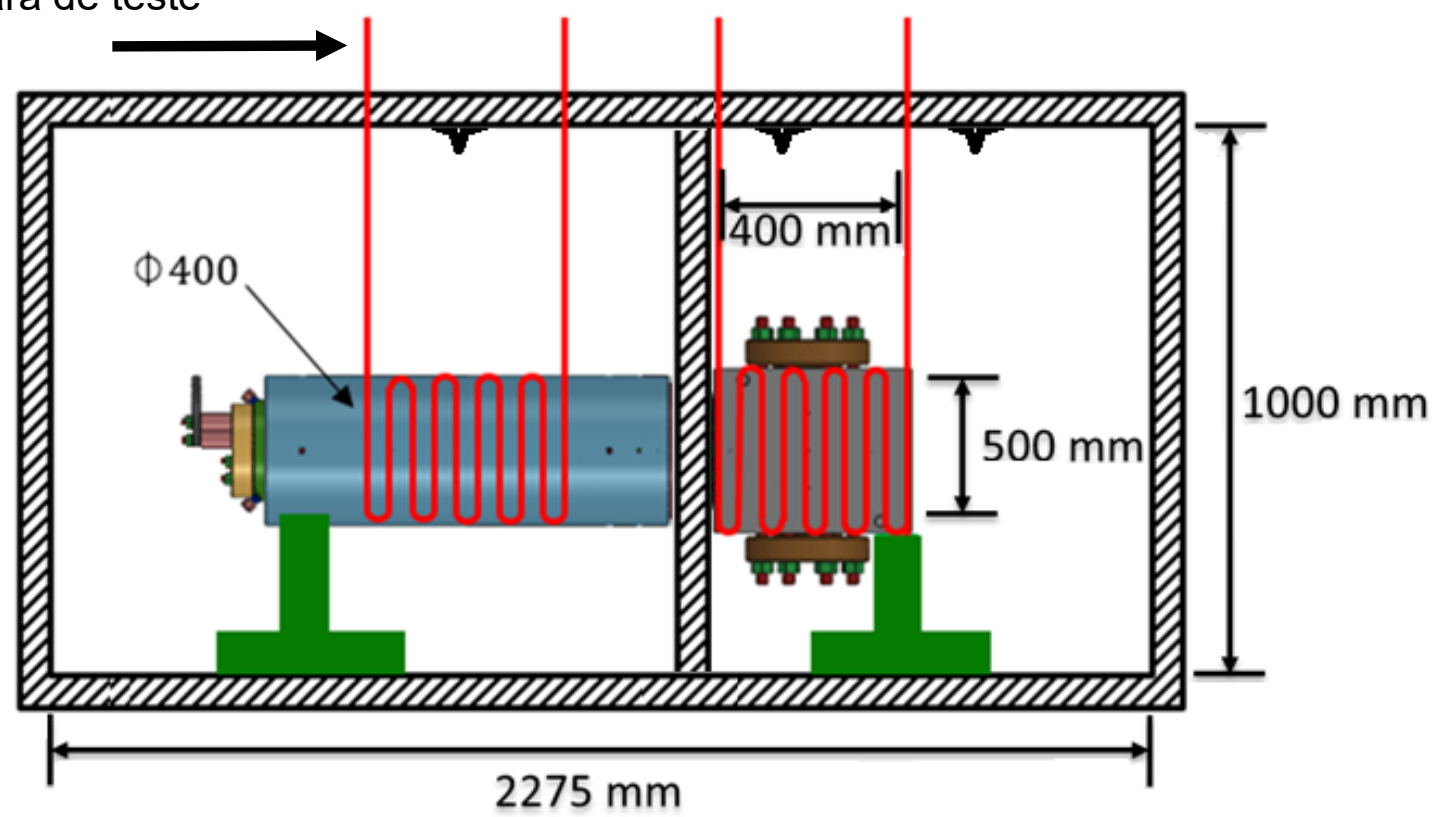

Figura 28 - Esquemático das resistências na câmara de testes

Foram utilizadas 4 resistências elétricas de $R=40 \Omega$. Além das duas unidades representadas na imagem acima, o setup do teste possui mais duas unidades, uma na parte inferior do corpo da válvula e a outra no outro lado do corpo da válvula.

Voltagem utilizada: $220 \mathrm{~V}$ - Trifásico

$$
\begin{gathered}
V=220 * \sqrt{3}=381 \mathrm{~V} \\
V=R I \\
I=\frac{V}{R}=9,5 \mathrm{~A} \\
P=V * I \\
P=220 * \sqrt{3} * 9,5 * 1=3619,98 \mathrm{~W}=3,62 \mathrm{~kW}
\end{gathered}
$$

São 4 resistências conectadas a quatro canais diferentes, sendo assim a potência total consumida pelas resistências é de 14,48 kW. 


\section{Teste da Câmara}

\subsection{Montagem do setup}

Conforme introduzido na seção 3.3, a montagem do setup compreende as seguintes etapas:

1) Posicionamento da câmara de teste para dentro da Cabine de Testes com Pressão;

2) Montagem das resistências elétricas no corpo e no atuador;

3) Posicionamento dos suportes dentro da câmara;

4) Assentamento do conjunto nos suportes dentro da câmara de teste;

5) Montagem da placa bipartida de divisão das zonas 1 e2;

6) Conectar a linha de alimentação do atuador e da válvula nos devidos pórticos de pressurização e unidades hidráulicas/ acumuladores; e

7) Fixar os transdutores de pressão e de temperatura nos locais indicados pelo projeto e conectá-los ao sistema de controle e aquisição de dados;

8) Fechar as tampas e montar os dispositivos de resfriamento de $\mathrm{N}_{2}$ e de ar comprimido nas tampas da câmara de testes; e

9) Fechar e travar porta da Cabine de Teste com pressão.

As Figuras 29 e 30 abaixo representam o setup montado para o teste. 


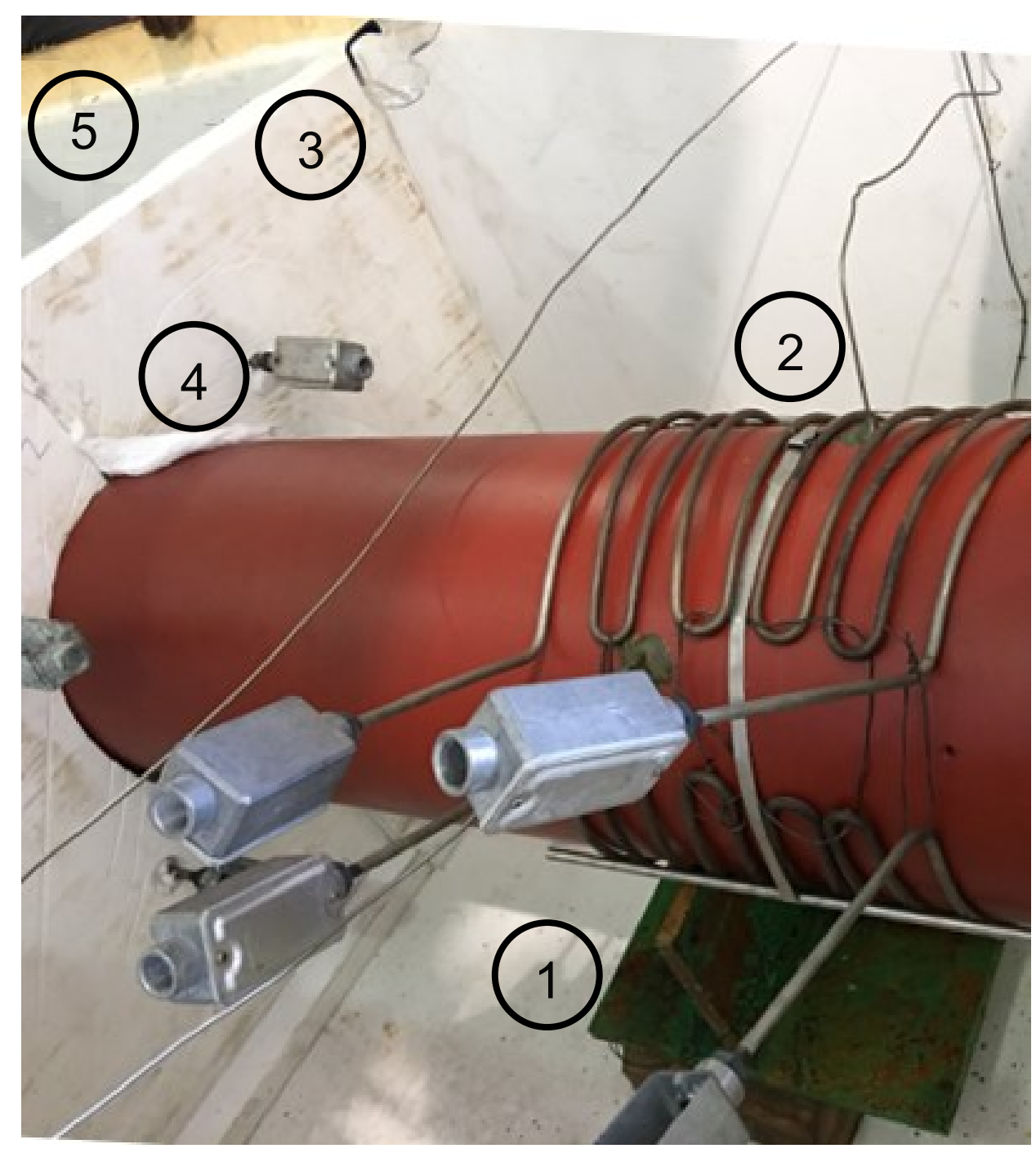

Figura 30 - Setup do Atuador na Zona 2 da Câmara

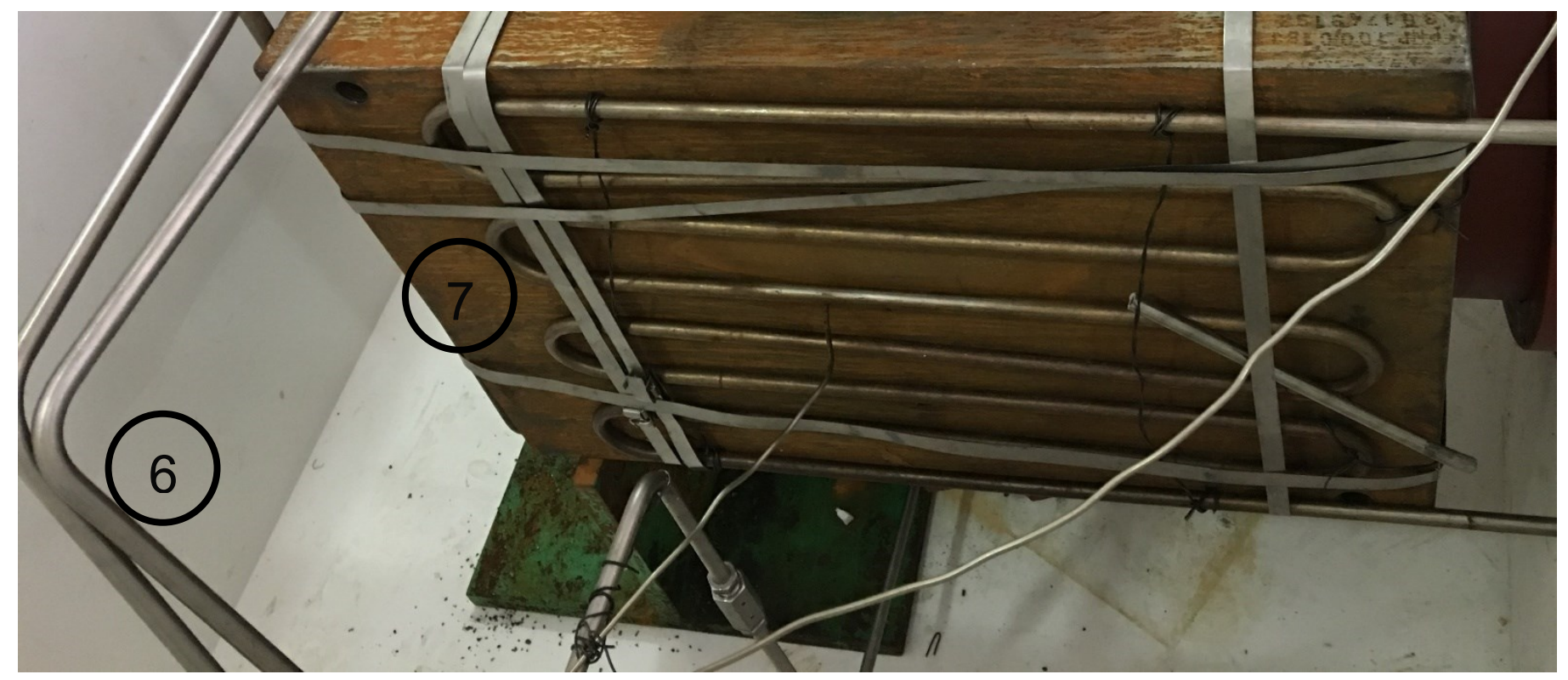

Figura 29 - Setup da válvula na Zona 1 da Câmara 
1 - Suporte

2 - Resistência elétrica do atuador

3 - Placa bipartida de 2" de Novolastic

4 - Pedaço de lã de vidro entre o corte da placa e o bonnet

5 - Zona 1

3 - Tubings de pressurização do corpo da válvula

4 - Resistências elétricas da válvula

É possível observar que as resistências são presas ao corpo com arame queimado e fita metálica não adesiva. O pedaço de lã de vidro foi colocado para vedar qualquer espaço entre o bonnet e o corte na placa bipartida de Novolastic $^{T M}$, pois com isso diminui-se a transferência de calor entre as zonas.

\subsection{Teste da Câmara}

O teste final foi realizado na válvula de 5" para a qual a câmara foi desenvolvida neste projeto. O procedimento do teste foi seguido conforme o apêndice $F$ da norma API $6 A$, descrito na seção 3.3 deste relatório. Sendo assim, foram executadas todas as etapas de pressurização e que não serão apresentadas neste relatório. Este é um dos motivos pelos quais não foi estudado a fundo o tempo de aquecimento e resfriamento do protótipo, apenas a estabilização das temperaturas máximas e mínimas e o comportamento da zona 2 ao aquecer e resfriar a zona 1.

No procedimento são previstos três ciclos de aquecimento e três ciclos de resfriamento enquanto o equipamento é pressurizado. Por isso, é esperado que as três curvas de resfriamento e as três de aquecimento não sejam diferentes entre si. 


\subsection{Resultados}

Em todos os testes deste relatório as temperaturas medidas são as do corpo (VG) e do atuador da válvula, não da zona 1 ou da zona 2. Este fato poderia acrescentar incertezas ao projeto, no entanto, o objetivo final da câmara não é o controle das temperaturas das zonas, mas o controle das temperaturas do corpo e do atuador.

A lógica do programa de controle trabalha independentemente em cada zona, buscando atingir uma temperatura alvo previamente definida, alinhando-a à média dos três RTDs de controle. Quando uma diferença entre esses valores é atingida, o técnico do teste muda a temperatura alvo para um valor previamente definido pelos engenheiros. O comportamento da curva da temperatura da zona 2 depende da temperatura da zona 1 pois o corpo da válvula (na zona 1) tem muito mais massa que o atuador (na zona 2) e necessita ser elevado a temperaturas muito mais altas ou baixas. Como o teste de pressão precisa ser executado com o corpo a $180^{\circ} \mathrm{C}$ e o atuador a $70^{\circ} \mathrm{C}$, não há necessidade de aquecer ou resfriar o atuador rapidamente até sua temperatura alvo máxima se o corpo não tiver atingido $180{ }^{\circ} \mathrm{C}$. A velocidade de aquecimento/resfriamento do corpo da válvula é o parâmetro que controla a programação do teste.

O primeiro gráfico apresentado na Figura 31 é o do teste completo, três ciclos de aquecimento e de resfriamento seguidos. Apesar da janela de visualização não ser a ideal, este o gráfico permite visualizar rapidamente o tempo total de teste bem como o tempo total de cada etapa. É possível obter uma boa estimativa do comportamento das curvas de temperatura do teste. 


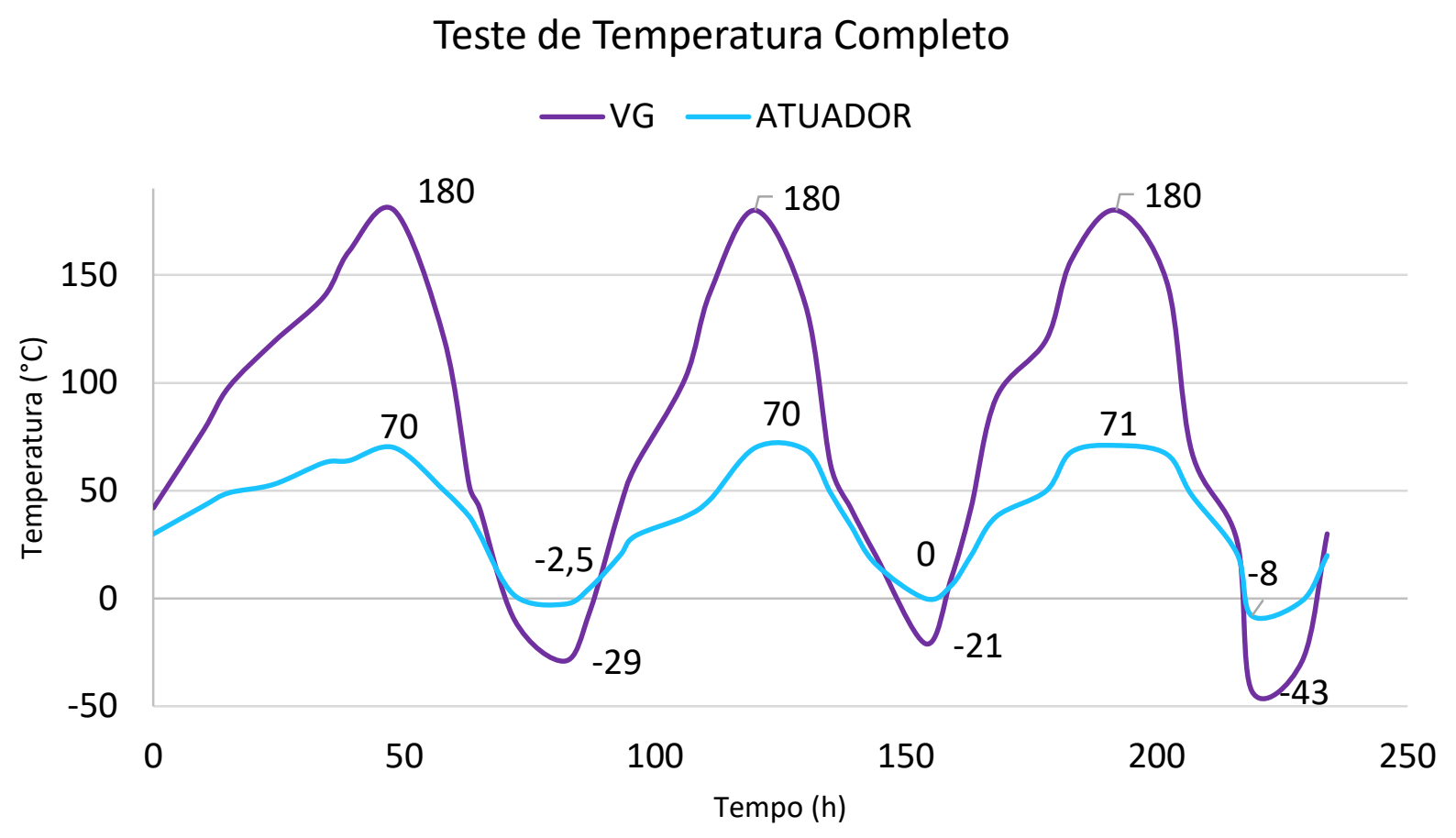

Figura 31 - Gráfico do teste de temperatura completo

O gráfico da Figura 31 foi dividido em ciclos. Cada ciclo começa com a válvula a $42{ }^{\circ} \mathrm{C}$ (temperatura ambiente - $\mathrm{T}_{\mathrm{AMB}}$ ). Nas Figuras 32 a 34 são apresentados primeiramente os ciclos de aquecimento, e em seguida os ciclos de resfriamento para facilitar a comparação dos resultados. 


\section{$1^{\circ}$ Ciclo de Aquecimento}

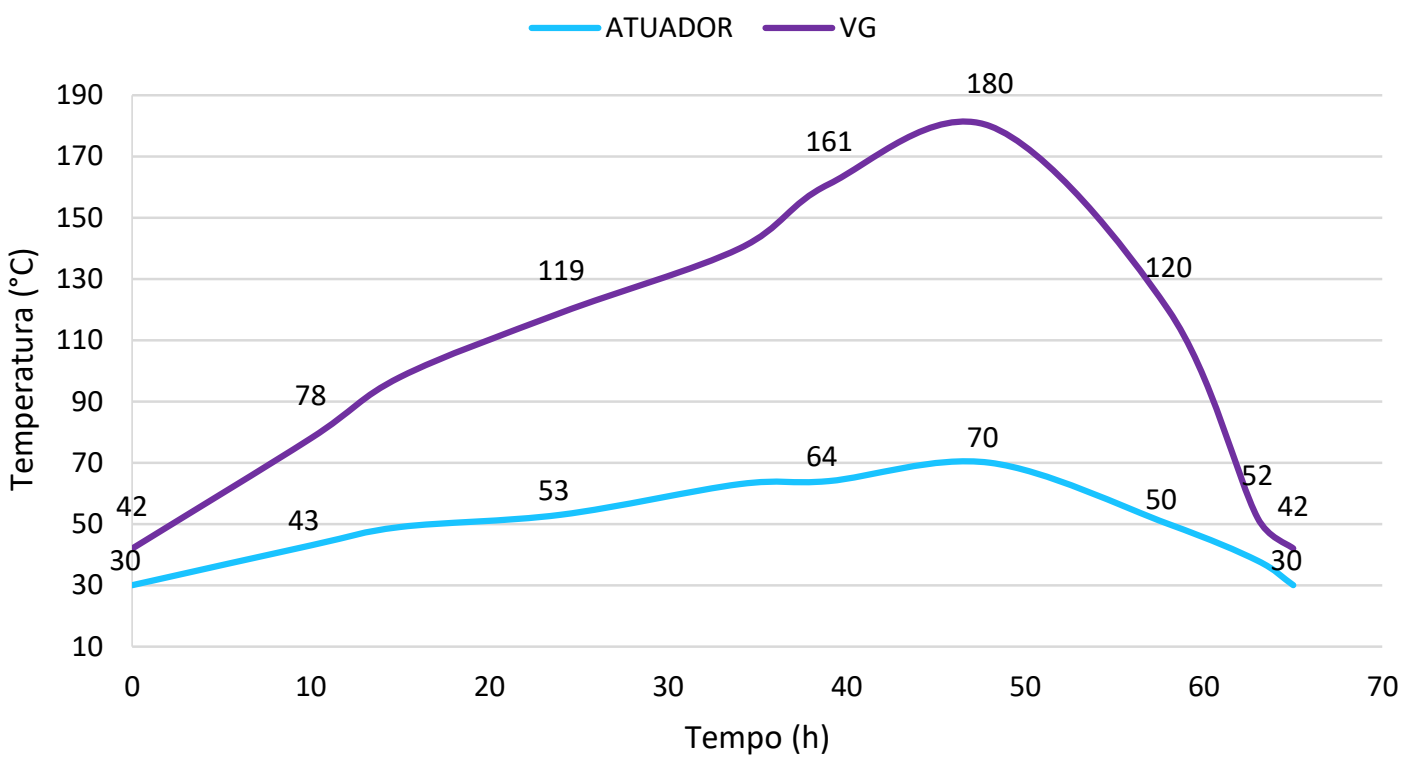

Figura 32 - Gráfico do $1^{\circ}$ Ciclo de Aquecimento

A Figura 32 apresenta o $1^{\circ}$ ciclo de aquecimento do teste, representando as etapas $\mathbf{a}, \mathbf{b}$ e metade da $\mathbf{c}$ do procedimento descrito na seção 3.3. O ciclo é inciado sem pressão e quando a válvula atinge $180^{\circ} \mathrm{C}$ e o atuador $70^{\circ} \mathrm{C}$ é aplicada uma pressão de 10000 psi a montante por uma hora e o conjunto é despressurizado ainda em suas temperaturas máximas. Em seguida, o retorno à temperatura ambiente é feito sem pressão.

Este aquecimento foi o mais demorado. Além do efeito de inércia nas resistências, que demoram a trocar calor considerável com o equipamento, a lógica do programa de controle foi programada para ter como temperatura alvo inicialmente de $90^{\circ} \mathrm{C} \mathrm{e}$, ao atingir $90^{\circ} \mathrm{C}$, foi reprogramada para $150^{\circ} \mathrm{C}$, e finalmente $180^{\circ} \mathrm{C}$. O controle da temperatura do atuador foi feito de forma análoga, primeiro a temperatura alvo foi de $50^{\circ} \mathrm{C}, 66^{\circ} \mathrm{C}$ e somente quando o corpo da válvula atingiu $170^{\circ} \mathrm{C}$, foi programado para o atuador atingir $70^{\circ} \mathrm{C}$. Mesmo com este controle manual do programa automatizado, é esperado que $o$ atuador atinja as temperaturas alvo do programa mais rapidamente que o corpo da válvula por ter menos massa.

O retorno à temperatura ambiente foi mais rápido do que esperado, comprovando que utilizar o dispositivo de resfriamento para injetar ar 
comprimido causa uma troca de calor por convecção forçada e resfria o conjunto, fazendo-o retornar à temperatura ambiente mais rapidamente.

Os resultados deste ciclo de aquecimento estão resumidos na Tabela 9.

Tabela 8 - Resultado do $1^{\circ}$ Ciclo de Aquecimento

$1^{\circ}$ Ciclo de Aquecimento

Tinicial $\left({ }^{\circ} \mathrm{C}\right)$

$\operatorname{Tmax}\left({ }^{\circ} \mathrm{C}\right)$

Válvula Atuador

Tfinal $\left({ }^{\circ} \mathrm{C}\right)$

Tempo de Aquecimento ( $h$ )

Tempo de retorno à Tinicial $(h)$

Taxa média de Aquecimento $\left({ }^{\circ} \mathrm{C} / \mathrm{h}\right)$

42

180

42

48

17

2,87 70 30 45 17 0,90

A Figura 33 apresenta o gráfico do $2^{\circ}$ ciclo de aquecimento do teste de temperatura.

\section{$2^{\circ}$ Ciclo de Aquecimento}

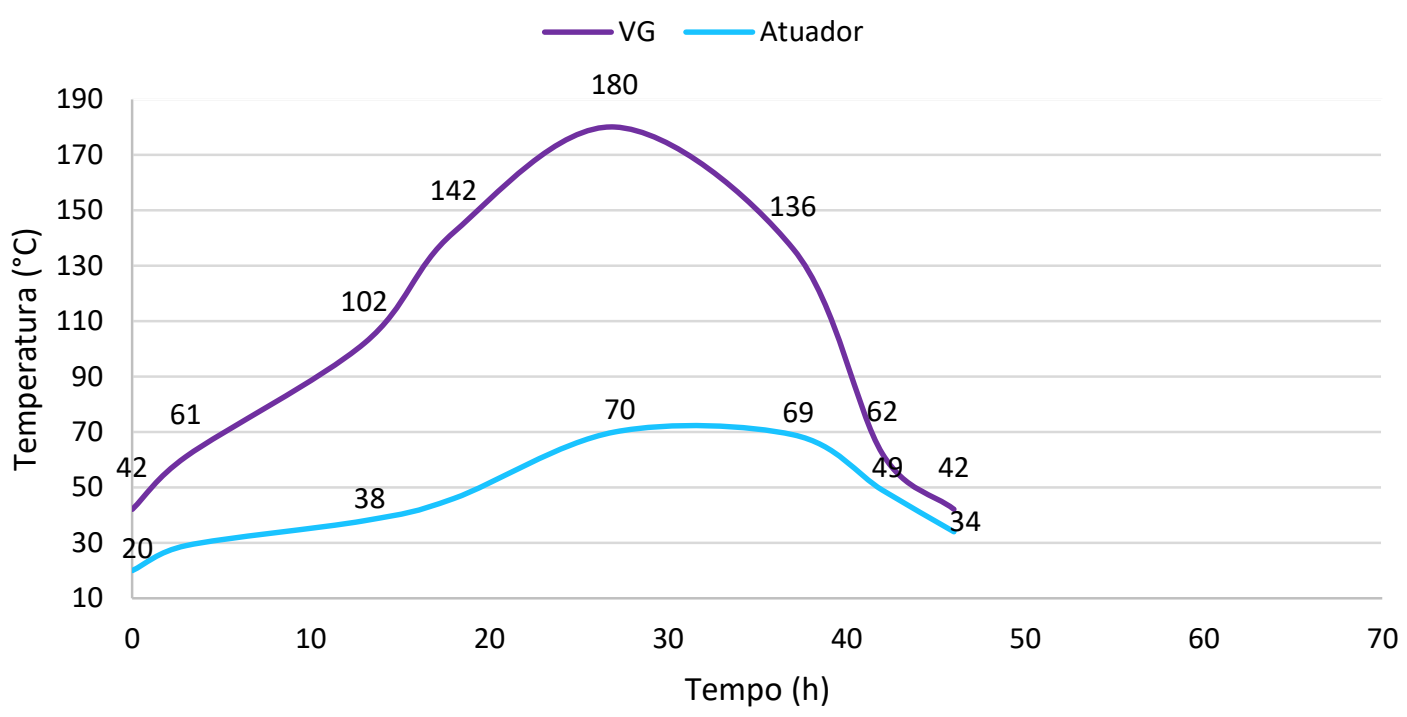

Figura 33 - Gráfico do $2^{\circ}$ Ciclo de Aquecimento

Este ciclo é a etapa de aquecimento com pressão, corresponde às letras $\mathbf{f}, \mathbf{g}$ e parte da $\mathbf{h}$ do gráfico da Figura 13 (seção 3.3). Durante toda a curva apresentada na Figura 33 a válvula estava vedando pressurizada, ou seja, estava sendo aplicada uma pressão de 10000 psi e a gaveta estava fechada. Este aquecimento com pressão foi mais rápido que o ciclo de aquecimento 
anterior, primeiramente porque as temperaturas alvo do corpo da válvula foram mais altas, $100^{\circ} \mathrm{C}$, e, ao se atingir esse alvo, $180^{\circ} \mathrm{C}$. A resistência elétrica do atuador só foi ligada quando a válvula atingiu $100^{\circ} \mathrm{C}$ e então seu alvo foi programado diretamente para $70{ }^{\circ} \mathrm{C}$. No entanto o atuador estava aquecendo, chegou a $50{ }^{\circ} \mathrm{C}$ como pode ser observado no gráfico. Essa variação de temperatura se deu exclusivamente pela condução de calor do corpo para o atuador, através do bonnet. Quando sua resistência foi ligada, o gráfico mostra que o resfriamento do atuador (partindo de $50^{\circ} \mathrm{C}$ até $70^{\circ} \mathrm{C}$ ) levou 7 horas.

O retorno à temperatura ambiente também foi com pressão à montante, e resfriado com injeção de ar comprimido. No entanto, pode-se perceber que este resfriamento ocorreu de forma mais lenta que o resfriamento sem pressão ( $1^{\circ}$ ciclo de aquecimento). Uma possível causa para isto pode ser o fato de que a injeção de ar comprimido na zona 2 só foi iniciada na $37^{a}$ hora deste ciclo, neste ponto iniciando-se o resfriamento do atuador. Até então sua resistência estava desligada, porém por condução do corpo da válvula e mesmo a temperatura da zona 2 mantiveram a temperatura do atuador em torno de $70{ }^{\circ} \mathrm{C}$ por algumas horas.

Os resultados deste ciclo de aquecimento estão resumidos na Tabela 10.

Tabela 9 - Resultado do $2^{\circ}$ Ciclo de Aquecimento

\section{$2^{\circ}$ Ciclo de Aquecimento}

Tinicial $\left({ }^{\circ} \mathrm{C}\right)$

$\operatorname{Tmax}\left({ }^{\circ} \mathrm{C}\right)$

Tfinal $\left({ }^{\circ} \mathrm{C}\right)$

Tempo de Aquecimento (h)

Tempo de retorno à Tinicial (h)

Taxa média de Aquecimento $\left({ }^{\circ} \mathrm{C} / \mathrm{h}\right)$
Válvula Atuador

$42 \quad 20$

$180 \quad 70$

$42 \quad 34$

$27 \quad 27$

$19 \quad 9$

$5,11 \quad 1,85$ 
A Figura 34 apresenta o $3^{\circ}$ ciclo de aquecimento do teste de temperatura.

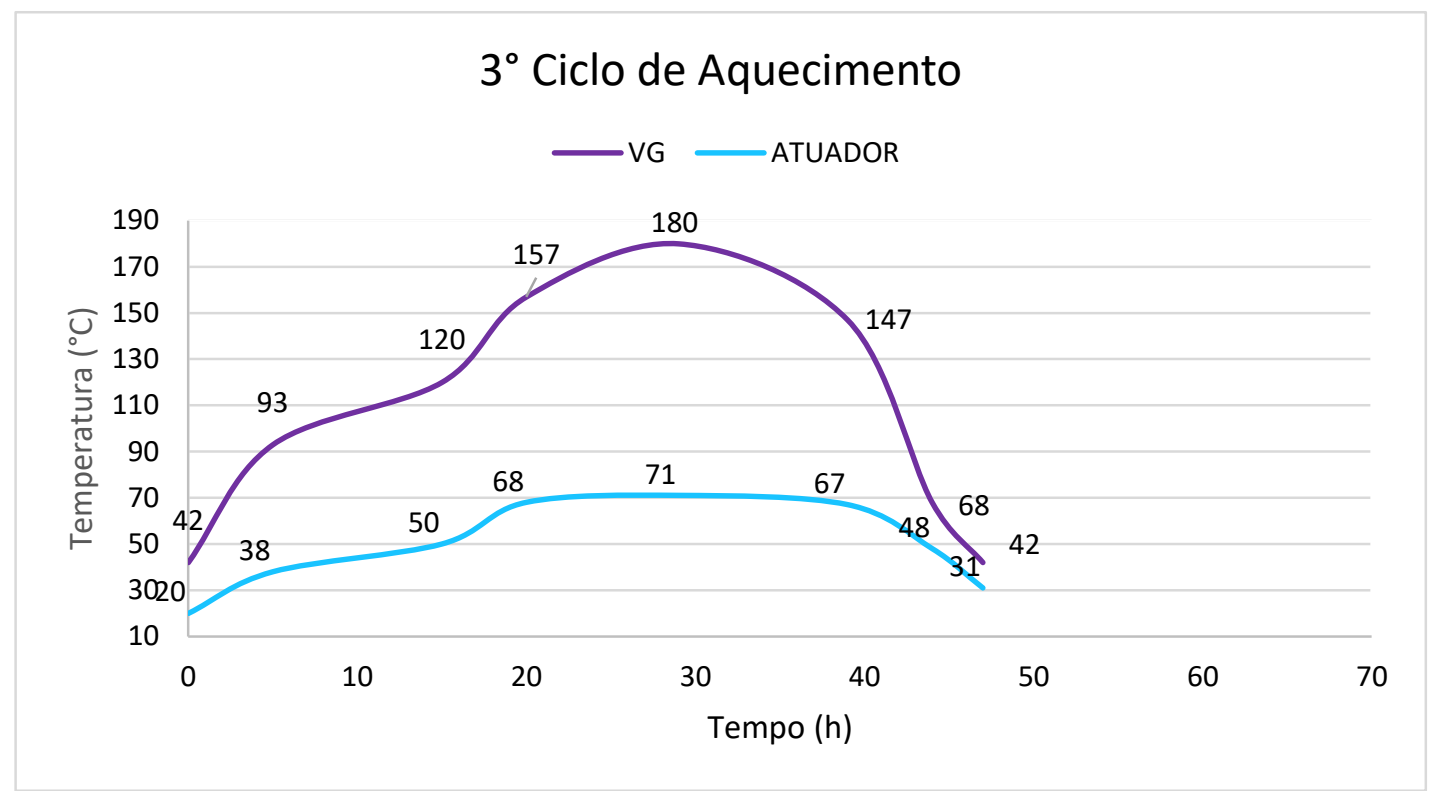

Figura 34 - Gráfico do $3^{\circ}$ ciclo de aquecimento

Este ciclo corresponde às etapas k, I e metada de $\mathbf{m}$ da Figura 13 (seção 3.3). É similar ao ciclo $1^{\circ}$ ciclo de aquecimento, aquecimento sem pressão, pressurização à montante e retorno à temperatura ambiente sem pressão. No entanto, este ciclo teve seu aquecimento muito mais rápido que $01^{\circ}$. Isto se deve ao fato do $1^{\circ}$ ciclo ter sido o primeiro teste da câmara. Com o resultado do $1^{\circ}$ ciclo foi possível melhorar a programação para este ciclo e otimizar o tempo de aquecimento. A diferença entre a temperatura alvo e a média dos 3 RTDs de controle foi ajustada de forma que a taxa de aquecimento aumentasse. Sendo assim, as temperaturas alvo continuaram a ser $90^{\circ} \mathrm{C}$, depois $150^{\circ} \mathrm{C}$ e então $180^{\circ} \mathrm{C}$. A resistência do atuador só foi ligada quando a o atuador atingiu $50^{\circ} \mathrm{C}$ e foi programado para ter seu alvo como $70^{\circ} \mathrm{C}$ diretamente. A injeção de ar comprimido da zona 2 só foi inciada quando a válvula atingiu $150^{\circ} \mathrm{C}$, na $35^{\mathrm{a}}$ hora deste ciclo.

Os resultados deste ciclo de aquecimento estão resumidos na Tabela 11. 
Tabela 10 - Resultado do $3^{\circ}$ Ciclo de Aquecimento

\section{$3^{\circ}$ Ciclo de Aquecimento}

Tinicial $\left({ }^{\circ} \mathrm{C}\right)$

Válvula Atuador

$\operatorname{Tmax}\left({ }^{\circ} \mathrm{C}\right)$

42

20

Tfinal $\left({ }^{\circ} \mathrm{C}\right)$

$180 \quad 71$

Tempo de Aquecimento (h)

42

31

Tempo de retorno à Tinicial $(\mathrm{h})$

29

29

Taxa média de Aquecimento $\left({ }^{\circ} \mathrm{C} / \mathrm{h}\right)$

18

15

4,76

2,55

A Figura 36 apresenta o $1^{\circ}$ ciclo de resfriamento do teste.

$1^{\circ}$ Ciclo de Resfriamento

-VG $=$ ATUADOR

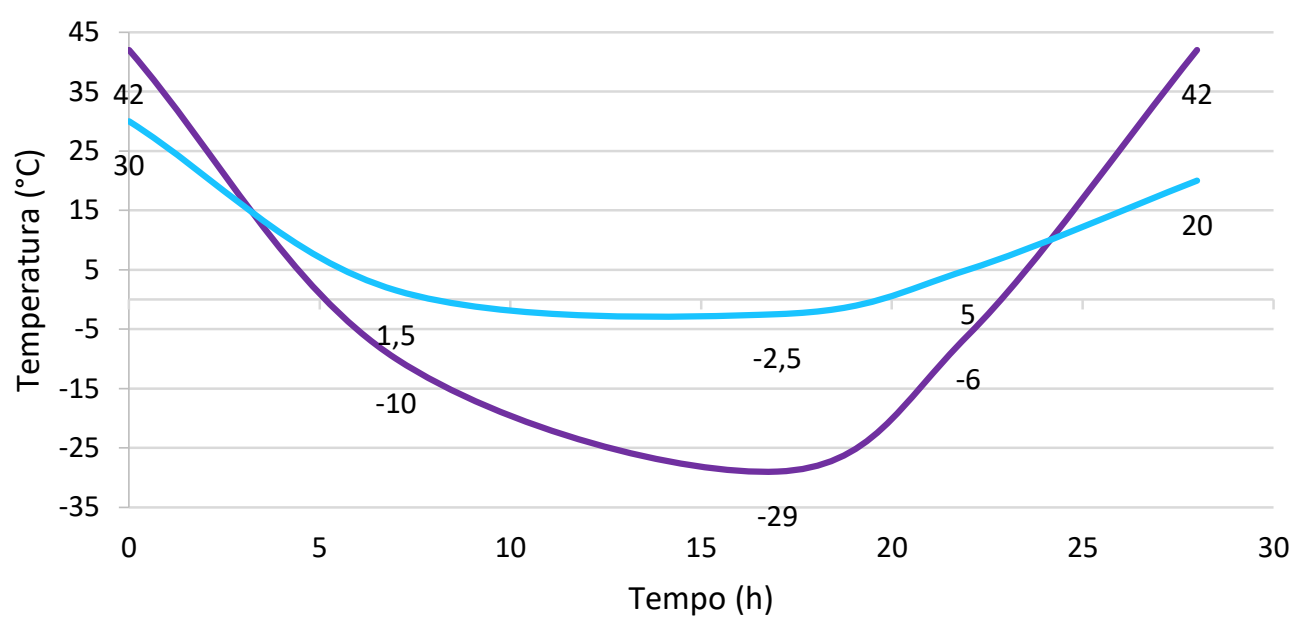

Figura 35 - Gráfico do $1^{\circ}$ Ciclo de Resfriamento

Este ciclo corresponde as etapas c, d e e do gráfico da Figura 13 (seção 3.3). As zonas foram resfriadas com gás $\mathrm{N}_{2}$, a temperatura alvo inicial do corpo foi de $-10{ }^{\circ} \mathrm{C}$ e a o atuador foi de $0{ }^{\circ} \mathrm{C}$. Após atingir essas temperaturas a alvo do corpo foi reprogramada para $-29{ }^{\circ} \mathrm{C}$ e a do atuador foi mantida a $0{ }^{\circ} \mathrm{C}$. Deve-se ter cuidado ao reduzir a temperatura do equipamento durante o teste, por isso, após a válvula atingir $-29{ }^{\circ} \mathrm{C}$, a diferença entre as temperaturas médias e a alvo foi reajustada de forma que a taxa de resfriamento diminuísse. Ou seja, o resfriamento do corpo entre $42{ }^{\circ} \mathrm{C}$ e -10 
${ }^{\circ} \mathrm{C}$ teve um taxa de resfriamento maior que entre $-10{ }^{\circ} \mathrm{C} \mathrm{e}-29^{\circ} \mathrm{C}$ (o que torna o teste mais rigoroso do que se fosse programado para $-18{ }^{\circ} \mathrm{C}$ ).

Pode-se concluir que, tanto o tempo de resfriamento quanto o de retorno à temperatura ambiente, forçado com injeção de ar comprimido, foram bons. Vale lembrar que a injeção de gás $\mathrm{N}_{2}$, assim como as resistências, não ficam ligados continuamente, ligando e desligando de acordo com a taxa programada.

Os resultados deste ciclo de resfriamento estão resumidos na Tabela 12.

Tabela 11 - Resultado do $1^{\circ}$ Ciclo de Resfriamento

$1^{\circ}$ Ciclo de Resfriamento

Tinicial $\left({ }^{\circ} \mathrm{C}\right)$

$\operatorname{Tmin}\left({ }^{\circ} \mathrm{C}\right)$

Tfinal $\left({ }^{\circ} \mathrm{C}\right)$

Tempo de Resfriamento $(\mathrm{h})$

Tempo de retorno à Tinicial $(\mathrm{h})$

Taxa média de Resfriaimento $\left({ }^{\circ} \mathrm{C} / \mathrm{h}\right)$

Válvula Atuador

42

$-29-2,5$

$42 \quad 20$

$17 \quad 7$

$11 \quad 8$

$-4,18 \quad-3,25$

A Figura 36 apresenta o $2^{\circ}$ ciclo de resfriamento do teste.

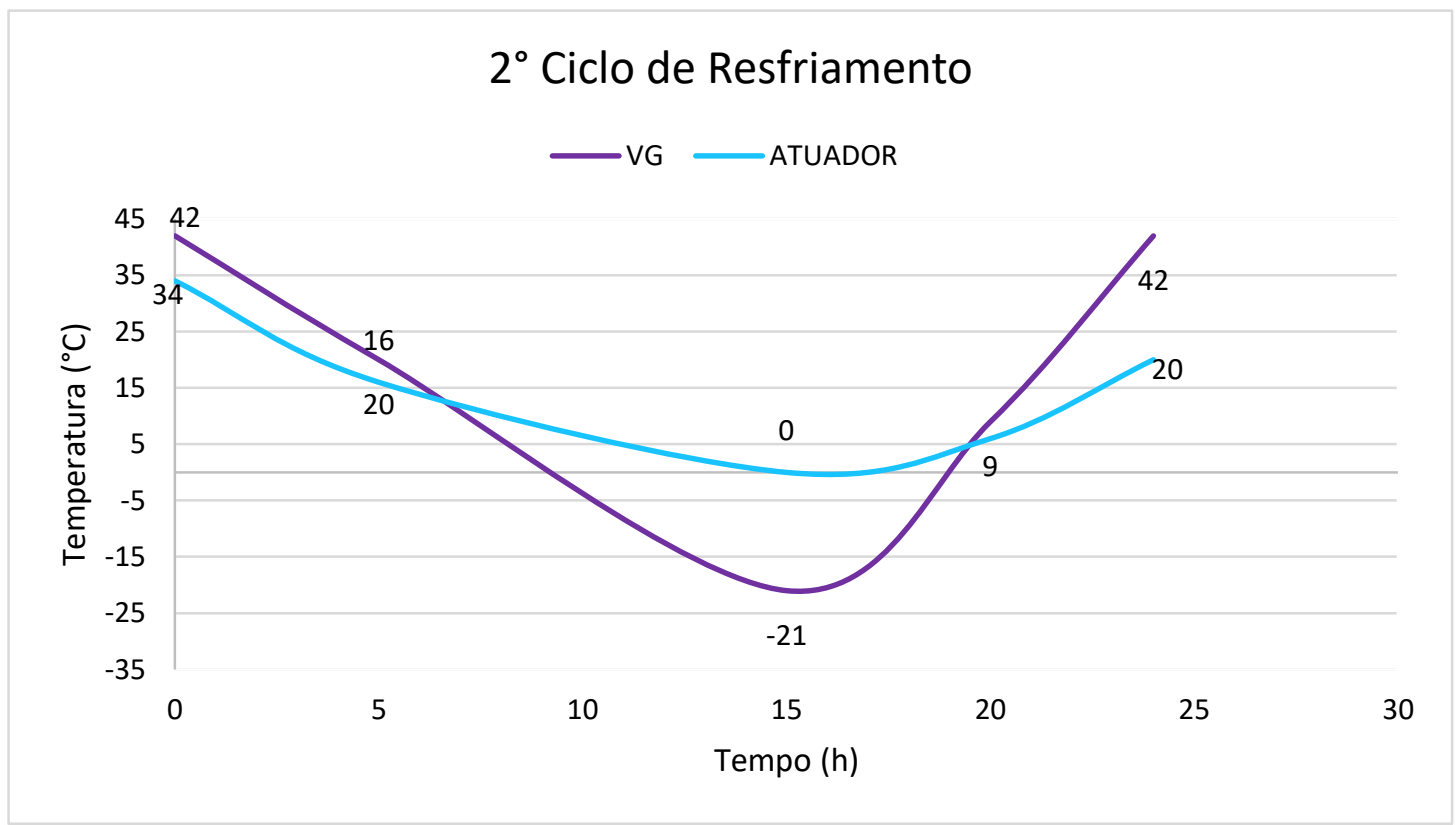

Figura 36 - Gráfico do $2^{\circ}$ ciclo de Resfriamento 
Este $2^{\circ}$ ciclo corresponde às etapas $\mathbf{h}, \mathbf{I}$ e j. São etapas realizadas com pressão a montante e por isso o controle da temperatura se torna um pouco mais difícil.

A temperatura alvo do corpo começou a $-18{ }^{\circ} \mathrm{C}$, e a injeção de gás $\mathrm{N}_{2}$ do atuador só foi iniciada quando a válvula atingiu temperatura negativa.

Os resultados deste ciclo de aquecimento estão resumidos na Tabela 13.

Tabela 12 - Resultado do $2^{\circ}$ Ciclo de Resfriamento

\section{$2^{\circ}$ Ciclo de Resfriamento}

Tinicial $\left({ }^{\circ} \mathrm{C}\right)$

$\operatorname{Tmin}\left({ }^{\circ} \mathrm{C}\right)$

Tfinal $\left({ }^{\circ} \mathrm{C}\right)$

Tempo de Resfriamento $(\mathrm{h})$

Tempo de retorno à Tinicial $(\mathrm{h})$

Taxa média de Resfriaimento $\left({ }^{\circ} \mathrm{C} / \mathrm{h}\right)$
Válvula Atuador

42

$-21$

42

15

13

$-4,20$
34

0

20

10

8

$-2,43$

A Figura 37 apresenta o $3^{\circ}$ ciclo de resfriamento mento do teste.

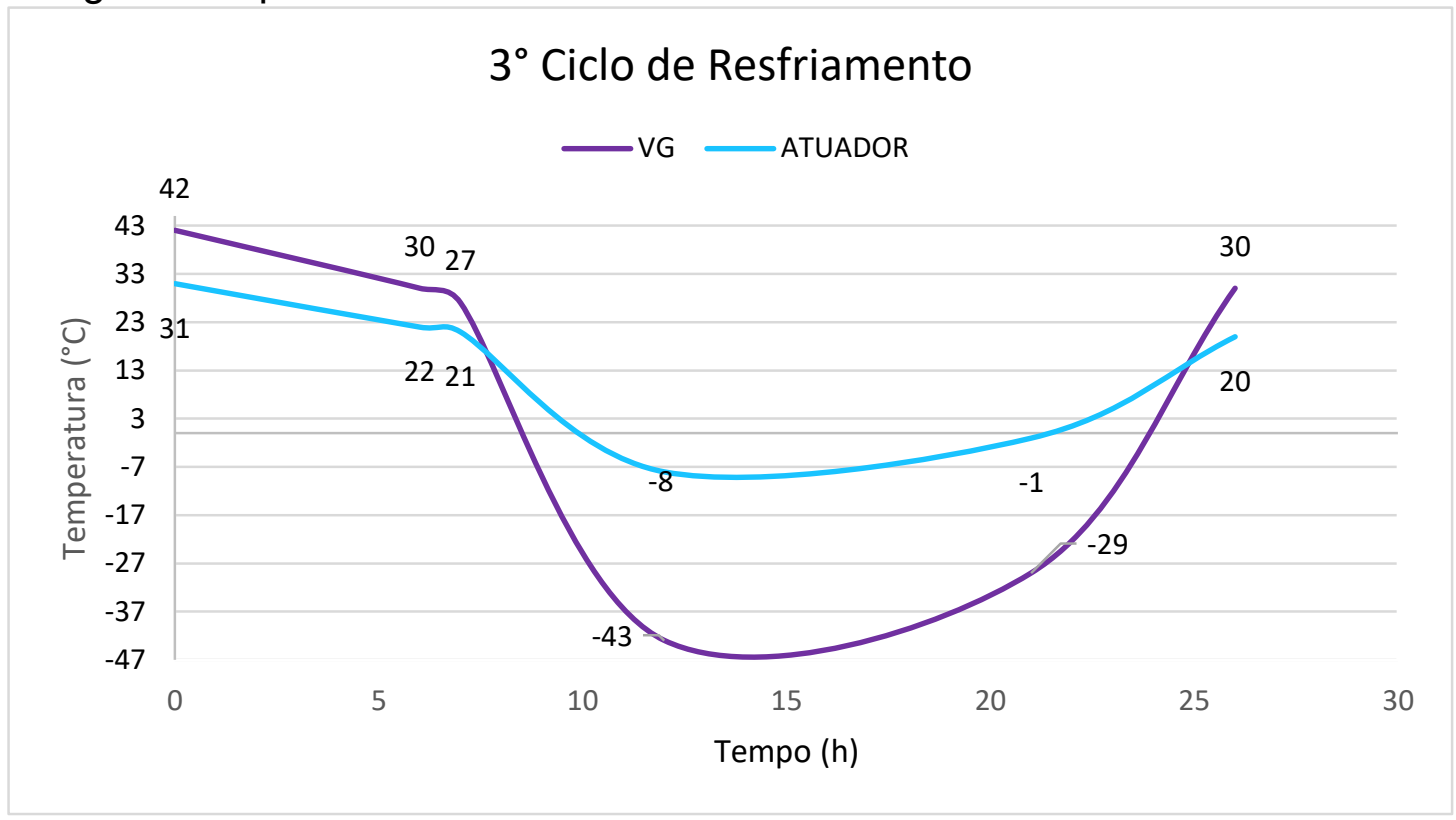

Figura 37 - Gráfico do $3^{\circ}$ ciclo de Resfriamento 
Este ciclo de resfriamento corresponde às etapas $\mathbf{m}, \mathbf{n}$ e $\mathbf{o}$ da Figura 13 (seção 3.3). Durante sua execução houve falha na válvula pneumática de controle de injeção de $\mathrm{N}_{2}$. Até a $7^{\mathrm{a}}$ hora de teste, a injeção não se mantinha por mais de meia hora, impossibilitando o resfriamento do corpo até a temperatura alvo, $-18^{\circ} \mathrm{C}$.

Quando o problema foi resolvido, foi programado para o corpo atingir $-18^{\circ} \mathrm{C}$ novamente e o atuador a $0{ }^{\circ} \mathrm{C}$, no entanto, a válvula pneumática, apesar de manter a injeção contínuamente, não respondeu à programação corretamente e resfriou o corpo a uma taxa maior do que a desejada. $\mathrm{O}$ corpo atingiu a temperatura mínima de $-43^{\circ} \mathrm{C}$ e o atuador $-8^{\circ} \mathrm{C}$.

Desta forma, o tempo de retorno à $\mathrm{T}_{\mathrm{AMB}}$ foi um pouco maior, mas a taxa de retorno não foi muito diferente das do $1^{\circ}$ e $2^{\circ}$ ciclo de resfriamento.

Os resultados deste ciclo de aquecimento estão resumidos na Tabela 14.

Tabela 13 - Resultado do $3^{\circ}$ Ciclo de Resfriamento

$\begin{array}{lcc} & 3{ }^{\circ} \text { Ciclo de Resfriamento } & \\ & \text { Válvula } & \text { Atuador } \\ \text { Tinicial }\left({ }^{\circ} \mathrm{C}\right) & 42 & 31 \\ \text { Tmin }\left({ }^{\circ} \mathrm{C}\right) & -43 & -8 \\ \text { Tfinal }\left({ }^{\circ} \mathrm{C}\right) & 30 & 20 \\ \text { Tempo de Resfriamento }(\mathrm{h}) & 10 & 10 \\ \text { Tempo de retorno à Tincial }(\mathrm{h}) & 18 & 8 \\ \text { Taxa média de Resfriaimento }\left({ }^{\circ} \mathrm{C} / \mathrm{h}\right) & -7,08 & -3,25\end{array}$

\subsection{Kaizen: Melhoria Contínua}

Kaizen significa melhoria contínua: Kai (mudança), zen (bom), "mudança para melhor". O propósito desta metodologia é buscar o aperfeiçoamento constante das situações. O caso mais conhecido de aplicação do método Kaizen é o da linha de produção da fabricante de carros Toyota, que aderiu ao sistema em 1950. Os principais objetivos desta filosofia são:

- Todo desperdício deve ser eliminado;

- Aprender na prática; e

- Melhoria contínua dos processos. 
Dito isto, mesmo que os requisitos de um projeto sejam atendidos, é provável que existirão pontos de melhoria. Neste projeto não foi diferente. Um exemplo de melhoria desta câmara pode ser a mudança no modelo das resistências elétricas para aquecimento, pois há muitas perdas na transferência de calor para o equipamento. Elas são arredondadas como pode ser visto nas Figuras 30 e 31 , e poderiam ser achatadas para que a transferência de energia térmica por condução fosse maior.

Outro ponto de melhoria deste projeto pode ser analisado com os resultados do protótipo. Apesar de não ser possível comparar os resultados de tempo de aquecimento e de resfriamento do teste no protótipo com o teste na câmara final, devido à diferença entre as massas da válvula de 2" e da válvula de 5", é intuitivo pensar que a otimização de volume interno da câmara contribuiu para um aquecimento mais rápido, pois estabiliza melhor a temperatura dos três RTDs de controle e logo, sua média atinge mais rapidamente a temperatura alvo do programa. O modelo de estrutura da câmara inicialmente desenvolvido para o projeto, estrutura de aço com dimensões otimizadas para tamanho da válvula, apresenta essas vantagens que serão testadas em breve no laboratório. 


\section{Conclusão}

Pode-se concluir que a câmara de testes não influencia diretamente na taxa de aquecimento/resfriamento do teste, esta depende do controle de uma programação. Assim, a velocidade de aquecimento e resfriamento é um parâmetro controlado pela programação no software, ao que parece, ainda é possível aumentar essa taxa de transferência, no entanto, é recomendado que seja alterada somente após um estudo detalhado sobre $\mathrm{O}$ comportamento microestrutural do material do equipamento.

Durante o teste as resistências são ligadas e desligadas assim como a válvula pneumática de injeção de gás $\mathrm{N}_{2}$ é aberta e fechada, o que altera a taxa de aquecimento/resfriamento do teste constantemente, bem como o gradiente de temperatura das zonas, dificultando o equilíbrio térmico. Além disso, esse acionamento e desacionamento constante das resistências e válvula pneumática desgasta o sistema pois, como pôde ser visto no $3^{\circ}$ ciclo de refrigeramento, houve uma falha mecânica da válvula pneumática.

Foi possível montar um setup simples e rápido que consumiu pouco tempo de teste e que ao final pôde ser facilmente desmontado. A estabilização da temperatura era um dos objetivos principais da câmara com isolamento de Novolastic $^{\mathrm{TM}}$ e o mesmo foi atingido.

O projeto atendeu às necessidades do teste e ao prazo de entrega ao laboratório, no entanto há possíveis pontos de otimização, como por exemplo a fabricação de uma estrutura de aço com dimensões otimizadas para tamanho da válvula a ser qualificada. 


\section{BIBLIOGRAFIA}

[1] https://www.google.com.br/patents/US6520261 . Acesso em 21/08/2017

[2] https://pt.scribd.com/presentation/100880189/API-6A - Acesso em $21 / 08 / 2017$

[3] http://www.indexmundi.com/pt/pre\%E7os-de- mercado/?mercadoria=pet r\%C3\%B3leo-bruto-brent\&meses=60 - Acesso em 19/11/2017

[4] http://webnordeste.com.br/2-uncategorised?start=36 - Acesso em $19 / 11 / 2017$ https://pt.scribd.com/document/243699680/API-6A-SpecificationOverviewb-pdf - Acesso em 21/11/2017

[6] FIGUEIREDO, C.T.C., VALE, M.S. , FIGUEIREDO, G.G., AUTT, S., ANÁLISE DE FALHAS EM VÁLVULA GAVETA DE UMA ÁRVORE DE NATAL MOLHADA

[7] MATHIAS, A. C. Válvulas: Industriais, Segurança, Controle: Tipos, Seleção, Dimensionamento. São Paulo: Artliber, 2008.

[8] A INFLUÊNCIA DOS PARÂMETROS DE OPERAÇÃO E PROJETO NO DESEMPENHO DE ATUAÇÃO HIDRÁULICA DE VÁLVULAS SUBMARINAS DO TIPO GAVETA/ Marcos Hideo da Silva Mashiba/setembro de 2011

[9] Ortiz Neto, José Benedito, and Armando João Dalla Costa. "A Petrobrás e a exploração de Petróleo Offshore no Brasil: um approach evolucionário". "Revista Brasileira de Economia 61.1 (2007): 95- 109".

[10] EUTHYMIOU, EJ. Metodologia para Testes Funcionais em Válvulas Submarinas. Diss. Tese de M. Sc., COPPE/UFRJ, Rio de Janeiro, RJ, Brasil, 2001.

[11] PAHL, G.; BEITZ, W.; FELDHUSEN, J.; GROTE, K. H. Projeto na Engenharia: Fundamentos do desenvolvimento e eficaz dos produtos, métodos e aplicações. $6^{\circ}$ Edição. São Paulo: Edgard Blücher, 2005.

[11] http://pt.knoema.com/ - acesso em 
[12] Dynamics and thermodynamic properties of CXCL7 chemokine Charles A. Herring, Christopher M. Singer, Elena A. Ermakova, Bulat I. Khairutdinov, [13] Yuriy F. Zuev, Donald J. Jacobs, Irina V. Nesmelova, 2015 (http://onlinelibrary.wiley.com/doi/10.1002/prot.24913/abstract)

[14] DE MORAIS, JOSÉ MAURO, PETRÓLEO EM ÁGUAS PROFUNDAS, Uma história tecnológica da PETROBRAS na exploração e produção offshore

[15] Peter Castro, Michael E. Huber, biologia marinha 8ed 2012 AMGH Editora

[16] EHLERS, Luiz, 2017 e as Expectativas do Setor de Petróleo e Gás Natural Brasileiro, Energyway (http://home.energyway.com.br/2017/01/25/2017-e-as-expectativas-dosetor-de-petroleo-e-gas-natural-brasileiro/ , acesso 19/11/2017)

[17] GABRIEL, Pedro, Equipamentos Submarinos 2014 (https://tecpetro.com/author/pagegabe/ , acesso 21/08/2017)

[18] CASTRO, Aline Capela Fernandes de. Determinação dos índices de sensibilidade ambiental ao derramamento de óleo do litoral da ilha de São Tomé [Dissertação de Mestrado]. Fortaleza: Universidade Federal do Ceará, 2010.

[19] ANP, ANUÁRIO ESTATÍSTICO BRASILEIRO DO PETRÓLEO, GÁS $\begin{array}{llll}\text { NATURAL } & \mathrm{E} & \mathrm{BIOCOMBUSTIVEIS} & 2016\end{array}$ (http://www.anp.gov.br/wwwanp/images/publicacoes/Anuario_Estatistico_A NP_2016.pdf)

[20]https://app.powerbi.com/view?r=eyJrljoiNDhjMDhiZDQtYjczNC00ZWYXL WJkNTAtZTIzNzMxMWYxMmRiliwidCI6ImJINGRmOTg2LTNIMzEtNDczOC 1iYjUwLTU2ZTIINDZkMTE5MiJ9 - acesso 19/11/2017 - Acesso em $02 / 12 / 2017$

[21] https://www.google.ch/patents/US6520261 - Acesso em 21/09/2017

[22] FREIRE, J.L.F., Engenharia de Dutos. 1 ed. Rio de Janeiro, ABCM, 2009.

[23] HERD, D.P., McCASKILL, J.W., "How to Make a Valve Which Will FailSafe in Very Deep Water". Joint Petroleum Mechanical Engineering and Pressure Vessels and Piping Conference, 76-PET-35, Mexico City, Federal District, Mexico,19-24 September 1976. 